\title{
Ligand Rearrangement and Hemilability in Rhodium(I) and Iridium(I) Complexes Bearing Terphenyl Phosphines
}

Juan José Moreno, María F. Espada, Eric Krüger, Joaquín López-Serrano, Jesús Campos,* and Ernesto Carmona

\begin{abstract}
We describe the synthesis of a series of cationic rhodium(I) and iridium(I) compounds stabilized by sterically demanding phosphines that contain a terphenyl substituent, $\mathrm{PMe}_{2} \mathrm{Ar}$ ' $\left(\mathrm{Ar}{ }^{\prime}=2,6-\right.$ diarylphenyl radical). Salt metathesis of metal precursors $\left[\mathrm{MCl}(\mathrm{COD})\left(\mathrm{PMe}_{2} \mathrm{Ar}{ }^{\prime}\right)\right](\mathrm{M}=\mathrm{Rh}, \mathrm{Ir} ; \mathrm{COD}=$ cyclooctadiene) with $\mathrm{NaBAr}_{\mathrm{F}}\left(\mathrm{BAr}_{\mathrm{F}}=\mathrm{B}\left(3,5-\mathrm{C}_{6} \mathrm{H}_{3}\left(\mathrm{CF}_{3}\right)_{2}\right)_{4}\right)$ results in a series of cationic complexes in which the loss of the chloride ligand is compensated by the appearance of relatively weak $\pi$-interactions with one of the flanking aryl rings of the terphenyl substituent. The same experiments carried out with carbonyl compounds $\left[\mathrm{MCl}(\mathrm{CO})_{2}\left(\mathrm{PMe}_{2} \mathrm{Ar}^{\prime}\right)\right]$ led to the corresponding cationic carbonyl complexes, whose CO-induced rearrangement reactivity has been investigated, both experimentally and computationally. The differences in reactivity between rhodium and iridium complexes, and as a result of varying the sterics of terphenyl phosphines are discussed.
\end{abstract}

\section{Introduction}

Phosphines are among the most widely used ancillary ligands in coordination and organometallic chemistry, largely due to the possibility of finely modulating their steric and electronic properties in a predictable manner. ${ }^{1}$ The range of physicochemical properties of transition metal complexes that can be tuned by the judicious choice of a phosphine ligand is exceptional. In particular, phosphines that contain bulky substituents have been successfully applied to stabilize a variety of low-coordinate transition metal complexes ${ }^{2}$ with important implications in catalysis. ${ }^{3}$ A notorious example is found in the work of Buchwald and coworkers, who synthesized in $1998^{4}$ the first example of a currently extensive family of biaryldialkyl phosphines.

The use of biaryl phosphines in homogeneous catalysis has found great success, particularly in palladium-catalysed cross coupling ${ }^{5}$ and amination reactions. ${ }^{6}$ Catalytic applications that rely on the combination of biaryl phosphines with iridium ${ }^{7}$ and rhodium ${ }^{8}$ precursors have also been described, although to a lesser extent. In a prominent example, Hartwig and co-workers demonstrated that the combination of $\left[\mathrm{Rh}(\mathrm{COD})_{2}\right] \mathrm{BF}_{4}(\mathrm{COD}=1,5$-cyclooctadiene $)$ and a biaryldialkyl phosphine functions as an excellent catalytic mixture for the intramolecular hydroamination of inactivated alkenes under mild conditions, ${ }^{9}$ with the active species containing the phosphine ligand bound to rhodium in a $\kappa^{1}, \eta^{6}$ 
coordination mode (A in Scheme 1). ${ }^{10}$ The group of Goldberg has investigated the chemistry of related rhodium complexes where the flanking aryl ring of several biaryl phosphines coordinates to the metal centre with variable hapticity. ${ }^{11}$ These studies were later extended to the corresponding iridium systems. ${ }^{12}$ While rhodium designs were active catalysts for arene hydrogenation, ${ }^{11}$ their iridium counterparts revealed their potential for transfer hydrogenation reactions. ${ }^{12}$ More recently, the usefulness of $\mathrm{Rh} /$ biaryl phosphine combinations for the selective and catalytic functionalization of $\mathrm{C}-\mathrm{H}$ bonds has been disclosed. ${ }^{13}$
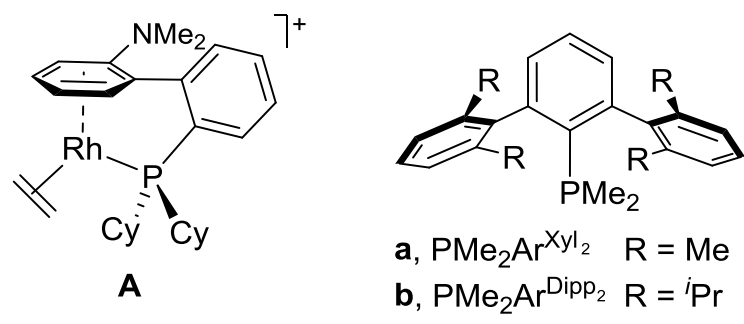

Scheme 1. (a) Key intermediate $\mathbf{A}$ in the Hartwig's Rh-mediated hydroamination of alkenes; (b) Terphenyl phosphine ligands employed in this work.

The ability of biaryl phosphines to function as hemilabile ligands by means of dynamic $\pi$-arene coordination seems to be crucial for its success in catalysis. ${ }^{6 a}, 14$ Although this type of coordination enhances the stability of the active species, catalyst decomposition remains a major limitation, as observed in Goldberg ${ }^{11}$ and Hartwig's ${ }^{10,15}$ systems. With this in mind, it is surprising that terphenyldialkyl phosphines, ${ }^{16}$ in which the biaryl substituent is replaced by a sterically more crowded terphenyl (2,6-diarylphenyl) group, have not been examined in deeper detail. We recently embarked to explore this type of ligands, ${ }^{17}$ demonstrating their potential to stabilize otherwise elusive organometallic frameworks. ${ }^{18}$ This work extends these studies to cationic rhodium and iridium systems bearing 1,5cyclooctadiene and ethylene ligands. Thus, we analyse the coordination modes of two terphenyl phosphine ligands, namely $\mathrm{PMe}_{2} \mathrm{Ar}^{\mathrm{Xyl}} 2$ and $\mathrm{PMe}_{2} \mathrm{Ar}^{\mathrm{Dipp}}$ (Scheme 1). In addition, we have synthesized rhodium and iridium cationic derivatives where the olefins have been substituted by CO ligands, and have observed a CO-induced ligand rearrangement in which phosphine hemilability plays a key role.

\section{Results and Discussion}




\section{Synthesis of $\operatorname{Rh}(I)$ and $\operatorname{Ir}(I)$ olefin compounds.}

Salt metathesis of chloride complexes 1 (1a: $\left.\mathrm{Ar}^{\prime}=\mathrm{PMe}_{2} \mathrm{Ar}^{\mathrm{Xyl} 2} ; \mathbf{1 b}: \mathrm{Ar}^{\prime}=\mathrm{PMe}_{2} \mathrm{Ar}^{\mathrm{Dipp} 2}\right)$, cleanly prepared by the $1: 1$ reaction of $[\mathrm{RhCl}(\mathrm{COD})]_{2}$ and the corresponding terphenyl phosphine, $17^{\mathrm{a}}$ with $\mathrm{NaBAr}_{\mathrm{F}}\left(\mathrm{BAr}_{\mathrm{F}}=\mathrm{B}\left(3,5-\mathrm{C}_{6} \mathrm{H}_{3}\left(\mathrm{CF}_{3}\right)_{2}\right)_{4}\right)$ in dichloromethane, afforded cationic complexes 2 quantitatively (Scheme 2). Chloride abstraction in compounds 1 triggers $\eta^{6}$-coordination of the $\pi$-system of one of the flanking aryl substituents of the phosphine, forcing the COD ligand to change its bidentate $\eta^{2}: \eta^{2}$ coordination mode to monodentate $\eta^{2}$-binding. Whereas there are examples of a phosphine aryl substituent coordinating to $\mathrm{Rh}(\mathrm{I})$ and $\operatorname{Ir}(\mathrm{I})$ in the $\eta^{6}$-mode while maintaining the $\mathrm{M}-\mathrm{P}$ bond,10,11,12 only a few complexes of these metals that exhibit monodentate COD ligand coordination have been reported. To our knowledge, prior to this work, no complexes of this kind had been structurally characterized for rhodium. ${ }^{19}$
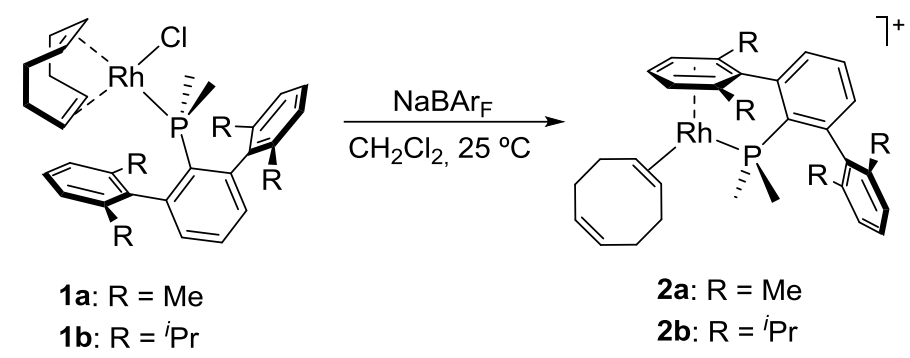

Scheme 2. Synthesis of cationic rhodium complexes $\mathbf{2}$ by chloride abstraction from $\mathbf{1}$.

The formulation proposed for complexes $\mathbf{2}$ in Scheme 2 was ascertained by NMR spectroscopy studies in solution and, in the case $\mathbf{2 a}$, also by X-ray crystallography. In the ${ }^{31} \mathrm{P}\left\{{ }^{1} \mathrm{H}\right\}$ NMR spectrum, a doublet at $c a .48 \mathrm{ppm}$, with a relatively large ${ }^{1} \boldsymbol{J}_{\mathrm{PRh}}$ coupling of $192 \mathrm{~Hz}$ was observed for both $\mathbf{2 a}$ and $\mathbf{2} \mathbf{b}$. Complex 2a shows fluxional behaviour in solution, as inferred from the presence of some broad signals in the ${ }^{1} \mathrm{H}$ NMR spectrum recorded at $25{ }^{\circ} \mathrm{C}\left(500 \mathrm{MHz}, \mathrm{CD}_{2} \mathrm{Cl}_{2}\right)$. Cooling at $0{ }^{\circ} \mathrm{C}$ allowed freezing the structure pictured in Scheme 2 on the NMR time scale, thereby permitting assigning all the ${ }^{1} \mathrm{H}$ and ${ }^{13} \mathrm{C}$ NMR resonances in their respective spectra (see Supporting Information). Two of the aromatic proton resonances of compounds 2 appear somewhat shielded at around $6.7\left(\mathrm{~d}, 2 \mathrm{H},{ }^{3} \mathrm{~J}_{\mathrm{HH}} c a .7 .5 \mathrm{~Hz}\right)$ and 5.9 ppm (t, $1 \mathrm{H},{ }^{3} J_{\mathrm{HH}} c a .7 .5 \mathrm{~Hz}$ ), in accordance with the proposed $\eta^{6}$-coordination of one of the flanking aryl substituent of the terphenyl group. This is in contrast with corresponding resonances being found above $7.2 \mathrm{ppm}$ for the analogous $\mathrm{H}$ atoms in the free lateral ring. In the ${ }^{13} \mathrm{C}\left\{{ }^{1} \mathrm{H}\right\}$ NMR spectrum of 2a, 
the associated ${ }^{13} \mathrm{C}$ nuclei appear at 112.1 and $97.1 \mathrm{ppm}$ for the Rh-bonded xylyl, and at 128.6 and 127.8 ppm for the non-coordinated xylyl substituent, and the same pattern is found for $\mathbf{2 b}$. A similar dichotomy was found between these NMR parameters of the olefinic $=\mathrm{CH}$ groups of the COD ligand, with the proton and carbon nuclei of the Rh-bonded $-\mathrm{CH}=\mathrm{CH}-$ moiety in 2 resonating at 3.38 and 74.0 $\operatorname{ppm}\left(\mathrm{d},{ }^{1} J_{\mathrm{CRh}}=13 \mathrm{~Hz}\right)$ respectively, and those corresponding to the uncoordinated $\mathrm{C}=\mathrm{C}$ bond at 5.55 and around $130 \mathrm{ppm}$.

At variance with $\mathbf{2 a}$, compound $\mathbf{2 b}$, based on the bulkier $\mathrm{PMe}_{2} \mathrm{Ar}^{\mathrm{Dipp} 2}$ phosphine, led to sharp signals in its corresponding ${ }^{1} \mathrm{H}$ NMR spectrum, with no sign of fluxionality on the NMR time scale. A plausible explanation for the dynamic behaviour of $\mathbf{2 a}$ could be the accomplishment of a fast dynamic equilibrium with unobserved amounts of an isomer featuring $\eta^{2}$-coordination of the xylyl ring and bidentate $\eta^{2}: \eta^{2}$-binding of the COD ligand at $25^{\circ} \mathrm{C}$. In fact, this latter structure was the preferred isomer in a related complex based on [(2-biphenyl)dicyclohexylphosphine] (CyJohnPhos).11 Taking in mind the importance of these $\pi$-arene interactions in catalysis, it is interesting to note that the prevalence of a particular $\pi$-coordination mode in these rhodium complexes containing biaryl or terphenyl phosphines may be modulated by the choice of the phosphorus ligand.

The proposed dynamic exchange between $\eta^{2}$ - and $\eta^{6}$-coordination modes of the arene substituent is further supported by investigations on the analogous iridium system. Chloride abstraction by $\operatorname{NaBAr}_{\mathrm{F}}$ from two iridium(I) compounds of formula $\left[\operatorname{IrCl}(\mathrm{COD})\left(\mathrm{PR}_{2} \mathrm{Ar}{ }^{\prime}\right)\right]\left(3 \mathbf{a}: \mathrm{Ar}^{\prime}=\mathrm{PMe}_{2} \mathrm{Ar}^{\mathrm{Xyl}}\right.$, and 3b: $\mathrm{Ar}^{\prime}=$ $\left.\mathrm{PMe}_{2} \mathrm{Ar}^{\mathrm{Dipp}}\right)^{17 \mathrm{a}}$ proceeded readily to yield cationic species 4 and $\mathbf{5}$. As depicted in Scheme 3 the equilibria between these complexes result from hapticity changes within both the flanking arene of the terphenyl substituent ( $\kappa^{1}$ vs. $\left.\eta^{6}\right)$ and the COD ligand $\left(\eta^{2}: \eta^{2}\right.$ vs. $\left.\eta^{2}\right)$. The equilibrium for $\mathbf{4 a}$ seems to be more rapid than in the rhodium analogue 2a, as inferred from the sharp resonances detected in the corresponding NMR spectra, and was confirmed by the presence of several exchange peaks in 2D EXSY experiments (see Figure S16). The isomeric distribution is phosphine dependent, with the smaller $\mathrm{PMe}_{2} \mathrm{Ar}^{\mathrm{Xyl}}{ }_{2}$ leading to isomer $4 \mathbf{a}$ as the major component (4a:5a; 59:41 ratio), whereas the more sterically congested $\mathrm{PMe}_{2} \mathrm{Ar}^{\mathrm{Dipp} 2}$ preferring $\mathrm{COD} \eta^{2}$, monodentate coordination accompanied by $\eta^{6}$ coordination of the flanking Dipp ring (4b:5b; 14:86 ratio).

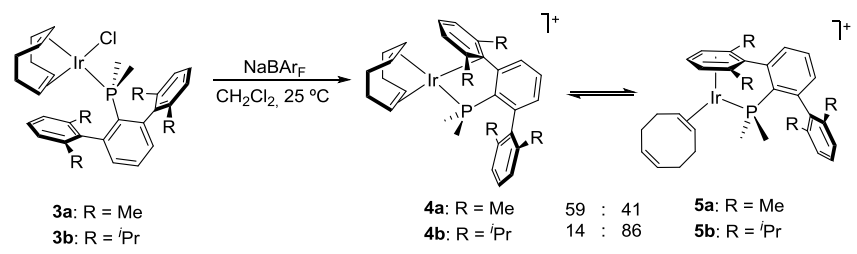

Scheme 3. Synthesis of complexes $\mathbf{4}$ and $\mathbf{5}$ by chloride abstraction from compounds 3 . 
The nature of isomers 4 and $\mathbf{5}$ was postulated on the basis of NMR spectroscopy, although the formulation of $\mathbf{4 a}$ was further confirmed by X-ray studies. Compounds 4 present a ${ }^{31} \mathrm{P}\left\{{ }^{1} \mathrm{H}\right\}$ resonance at around $15 \mathrm{ppm}$, slightly deshielded (ca. $2 \mathrm{ppm}$ ) relative to their $\eta^{2}$-COD isomers 5 . In the latter, $\eta^{6}$ coordination of the flanking arene is ascertained by the somewhat upfield signals at $6.6\left(\mathrm{~d}, 2 \mathrm{H},{ }^{3} \mathrm{~J}_{\mathrm{HH}}=6\right.$ $\mathrm{Hz})$ and $5.7\left(\mathrm{t}, 1 \mathrm{H},{ }^{3} J_{\mathrm{HH}}=6 \mathrm{~Hz}\right) \mathrm{ppm}$. The two distinctive peaks recorded at around 5.6 and $2.9 \mathrm{ppm}$ due to the COD fragment evince that only one of the two olefinic moieties is bound to iridium. In contrast, a set of two resonances in the interval 3.2 to $3.4 \mathrm{ppm}$ in compounds 4 is consistent with the $\eta^{2}: \eta^{2}$-coordination proposed for COD. In fact, this latter formulation is similar to that previously reported for related iridium complexes based on biaryldialkyl phosphines. ${ }^{12}$ For this system, however, isomers alike $\mathbf{5}$ were not detected and no sign of solution equilibrium was noticed.

The addition of pyridine to the equilibrium mixture $\mathbf{4 a} / \mathbf{5} \mathbf{a}$ results in quantitative formation of compound 6a, a sterically encumbered version of the widely used Crabtree's catalyst (Scheme 4). ${ }^{20}$ The latter, as well as many other cyclooctadiene $\operatorname{Ir}(\mathrm{I})$ compounds bearing phosphine ligands, have found ample use in catalysis, ${ }^{21}$ highlighting the potential of compounds alike $\mathbf{6 a}$ for these purposes. This is a research avenue that we are currently pursuing in our laboratories. The $\kappa^{1}-\mathrm{P}$ monodentate coordination of the phosphine in 6a is confirmed by the symmetric pattern observed for its deshielded (7.1 - 7.6 ppm) aromatic ${ }^{1} \mathrm{H}$ NMR resonances, and by the presence of two signals, each corresponding to two protons, at 3.49 and $3.98 \mathrm{ppm}$, denoting $\eta^{2}: \eta^{2}$-coordination of cyclooctadiene. In turn, the corresponding ${ }^{31} \mathrm{P}\left\{{ }^{1} \mathrm{H}\right\}$ NMR band of $\mathbf{6 a}$ appears at lower frequency $(-12.1 \mathrm{ppm})$ than in isomers $\mathbf{4 a}(16.9 \mathrm{ppm})$ and $\mathbf{5 a}(2.0$ ppm), i. e. shifted to higher frequency by only ca. $30 \mathrm{ppm}$ relative to free phosphine.

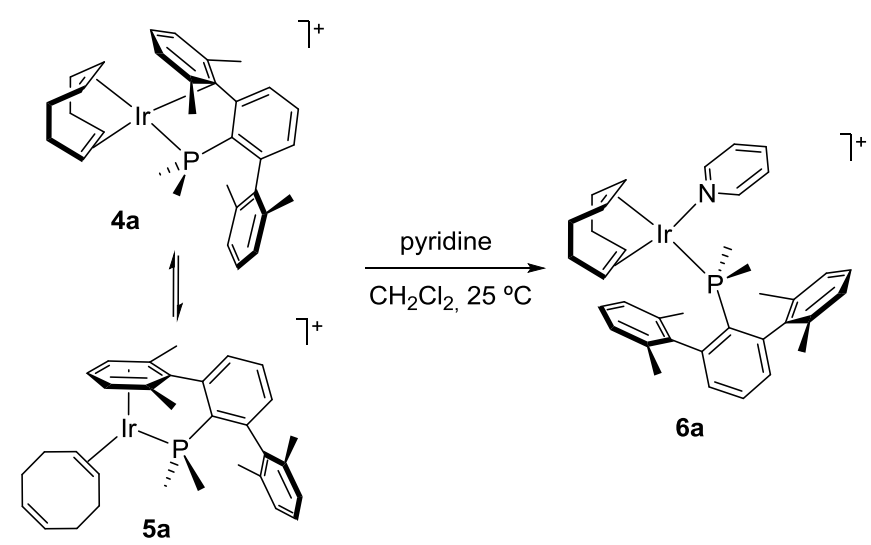

Scheme 4. Synthesis of pyridine adduct $6 \mathbf{a}$. 
As anticipated, the solid state structures of complexes $\mathbf{2 a}$ and $\mathbf{4 a}$ were confirmed by single crystal X-ray studies. Figure 1 depicts the molecular structures of the cations of $\mathbf{2 a}$ and $\mathbf{4 a}$. As can be seen in the structure of $\mathbf{2 a}$, its $\mathrm{Rh}(\mathrm{I})$ centre is formally five-coordinate to one of the $\mathrm{C}=\mathrm{C}$ bonds of $\mathrm{COD}(\mathrm{C} 1-\mathrm{C} 2)$, one of the flanking $\eta^{6}$-aryl ring $(\mathrm{C} 7-\mathrm{C} 12)$, and the phosphorus atom of the phosphine ligand. The Rh$\eta^{2}$-COD linkage is characterized by $\mathrm{Rh}-\mathrm{C}$ bonds with length $c a$. $2.15 \AA$, comparable to other known $\mathrm{Rh}(\mathrm{I})$-alkene units. The $\mathrm{Rh}(\mathrm{I})-\eta^{6}$-arene moiety presents, however, relatively long $\mathrm{Rh}-\mathrm{C}$ bonds, with the exception of the Rh- $C_{i p s o}$ contact (Rh1-C15 in Figure 1), which at 2.142(4) $\AA$ is practically identical to the $\mathrm{Rh}-\mathrm{COD}$ bond distances. The remaining $\mathrm{Rh}-\mathrm{C}$ bonds to the $\eta^{6}$-aryl ring have lengths in the range 2.30-2.35 А. These separations are similar to, albeit somewhat longer, than those reported for other $\mathrm{Rh}(\mathrm{I})$-arene complexes. ${ }^{22}$ This coordination mode clearly differs from that of $\mathbf{4 a}$, where the geometry around iridium is square planar, encompassing binding to phosphorus, $\eta^{2}: \eta^{2}$-coordination to COD and a $\kappa^{1}, \pi$-arene interaction with a flanking aryl ring. The Ir-C bond distances within the Ir- $\eta^{2}-\mathrm{COD}$ fragments have normal values, with those in trans to phosphorus being slightly elongated (ca. $2.24 \AA$ ) with respect to those trans to the $\pi$-arene interaction (ca. $2.12 \AA$ ), as a result of the stronger trans influence of the phosphine. At variance with previous related systems based on biaryl phosphines that exhibit $\eta^{2}$-arene coordination defined by two close $\mathrm{M}-\mathrm{C}_{\text {arene }}$ distances, ${ }^{11,12}$ the terphenyl phosphine of complex $\mathbf{4 a}$ is mainly coordinated through the phosphorous terminus and through the ipso carbon atom of a lateral aryl ring (Figure 1). The latter interaction is relatively strong, with an Ir1-C7 contact of 2.308(4) $\AA$ that supports $\kappa^{1}-\mathrm{P}, \kappa^{1}-\mathrm{C}_{\text {arene }}$ phosphine binding. ${ }^{23}$ Nonetheless, a slim tilt is noticeable in the interacting aryl substituent, and this distortion breaks the symmetry along the Ir- $\pi$-arene moiety facilitating the approach of one of the ortho carbon atoms. As a result, an Ir1-C8 contact of 2.609(7) $\AA$ can be measured, which is significantly shorter than the $\operatorname{Ir} 1-\mathrm{C} 12$ separation of $2.878(8) \AA$ to the other ortho carbon atom. In principle, a non-symmetrical $\eta^{2}$-coordination of the anchored arene cannot be disregarded. ${ }^{24}$

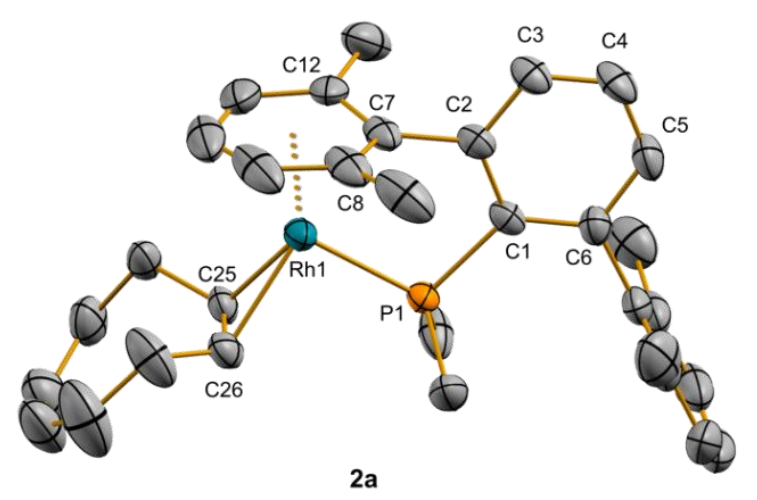




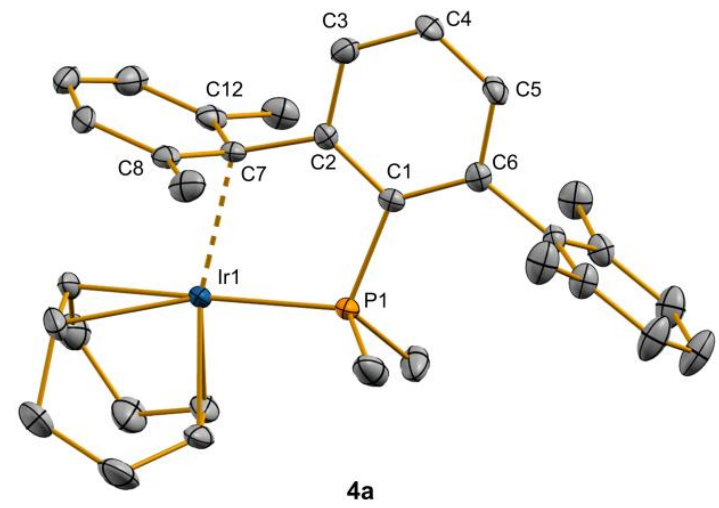

Figure 1. ORTEP view of the cations of complex 2a and 4a; hydrogen atoms are excluded for clarity and thermal ellipsoids are set at $50 \%$ level of probability.

To complete this series of $\operatorname{Rh}(\mathrm{I}) / \mathrm{Ir}(\mathrm{I})$ olefin compounds we targeted ethylene structures analogous to Hartwig's key intermediate in hydroamination reactions (A in Scheme 1). ${ }^{10}$ Accordingly, the ethylene rhodium (7) and iridium (8) adducts, closely related to complexes $\mathbf{2}$ and $\mathbf{5}$, respectively, were cleanly obtained from the reactions of the corresponding dimers $\left[\mathrm{MCl}\left(\mathrm{C}_{2} \mathrm{H}_{4}\right)_{2}\right]_{2}\left(\mathrm{M}=\mathrm{Rh}\right.$, Ir) with $\operatorname{NaBAr}_{F}$ in the presence of the phosphine $\left(\mathrm{CH}_{2} \mathrm{Cl}_{2}, 25{ }^{\circ} \mathrm{C}\right.$, Scheme 5). Addition of $\mathrm{NaBAr}_{\mathrm{F}}$ proved essential to favour quantitative formation of the desired ethylene adducts, as in its absence, cationic compounds 7 and $\mathbf{8}$ with chloride as counteranion formed along with various other species containing a metal-bound chloride ligand. Once more, the new compounds were characterized by microanalysis and NMR spectroscopy. The ${ }^{1} \mathrm{H}$ and ${ }^{13} \mathrm{C}\left\{{ }^{1} \mathrm{H}\right\}$ NMR spectra are in accord with the proposed $\eta^{6}$-coordination of one of the phosphine aryl substituents. In turn, in rhodium compounds 7, the ethylene ligand undergoes fast rotation on the NMR time scale at $25{ }^{\circ} \mathrm{C}$, such that the four hydrogen atoms give rise to broad ${ }^{1} \mathrm{H}$ NMR resonances at around $2.9 \mathrm{ppm}$, while the ${ }^{13} \mathrm{C}$ nuclei resonate as a doublet in the proximity of $46 \mathrm{ppm}$ $\left({ }^{1} J_{\mathrm{CRh}}=13 \mathrm{~Hz}\right)$. Ethylene rotation is hindered in their iridium analogues, reflecting the stronger Ir- $\eta^{2}-$ $\mathrm{C}_{2} \mathrm{H}_{4}$ bond when compared to $\mathrm{Rh}-\eta^{2}-\mathrm{C}_{2} \mathrm{H}_{4}$ bond due to the iridium higher basicity. This fact is 
evidenced by two distinctive signals at around 1.7 and $3.0 \mathrm{ppm}$ due to the ethylene ligand in the ${ }^{1} \mathrm{H}$ NMR spectra of compounds 8 . The corresponding ${ }^{13} \mathrm{C}\left\{{ }^{1} \mathrm{H}\right\}$ NMR resonance appears at $c a .24 \mathrm{ppm}$. The ${ }^{13} \mathrm{C}$ signals of the $\mathrm{C}_{2} \mathrm{H}_{4}$ ligand in complexes 8 are therefore shielded by more than $20 \mathrm{ppm}$ with respect to those in the rhodium analogues, evincing a higher $\mathrm{sp}^{3}$ character of the carbon atoms as a consequence of increased $\pi$-back donation from the $\operatorname{Ir}(\mathrm{I})$ centre. It is widely accepted that the low-frequency shift of the olefin carbon atoms relative to free ethylene $(122.8 \mathrm{ppm})$ increases with $\pi$-back bonding. ${ }^{25}$ The structure of compound $\mathbf{7 b}$ was authenticated by X-ray diffraction studies (Figure S5). The bound ethylene molecule presents a C-C bond distance of 1.386(6) $\AA$, nearly identical to that of the related ethylene adduct reported by Hartwig (A in Scheme 1$)^{10}$ and close to the $1.37 \AA$ distance in Zeise's salt. ${ }^{26}$ The remaining geometric parameters are essentially similar to those measured in structures $\mathbf{A}$ and

2a.

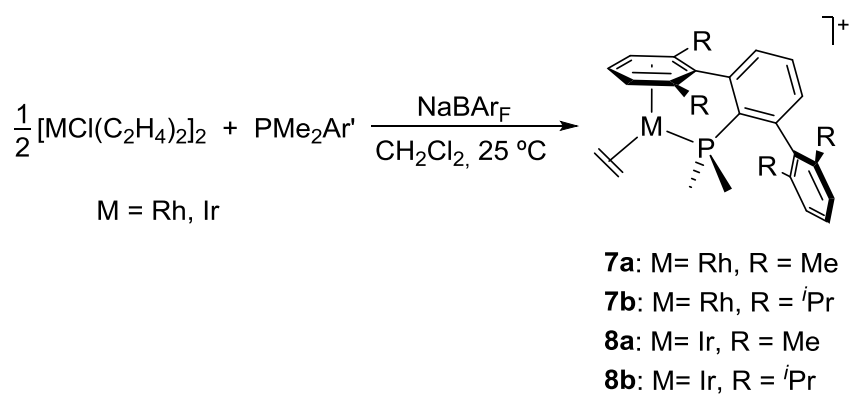

Scheme 5. Synthesis of complexes 7 and $\mathbf{8}$.

\section{Synthesis of rhodium and iridium carbonyl compounds}

Substitution of cyclooctadiene by two CO ligands in this type of complexes has been amply utilized to gauge the electronic properties of ancillary ligands, ${ }^{27}$ particularly bulky phosphines, as well as to access catalysts with enhanced performance. ${ }^{28}$ For instance, using this method we proved that the basicity of terphenyl phosphines $\mathrm{PMe}_{2} \mathrm{Ar}^{\mathrm{Xy}}{ }_{2}$ and $\mathrm{PMe}_{2} \mathrm{Ar}^{\mathrm{Dipp}} 2$ is comparable to that of the related widely employed $\mathrm{PR}_{2}$ Ar biarylphosphines. ${ }^{17,29}$

We now decided to extend the chemistry of our neutral carbonyl compounds to more reactive cationic rhodium and iridium derivatives, once again by means of chloride abstraction. Treatment of $\mathrm{CH}_{2} \mathrm{Cl}_{2}$ solutions of 9 and 10 with $\mathrm{NaBAr}_{F}$ cleanly generated the desired cationic carbonyl complexes, although the outcome of the reaction was dependent on the selected metal. For instance, under the conditions of Scheme 6, rhodium precursors 9 led to monocarbonyl compounds $\mathbf{1 1} \cdot \mathbf{C O}$, whereas the iridium analogs provided dicarbonyl complexes $\mathbf{1 2} \cdot(\mathbf{C O})_{2}$ (Scheme 6). Once again, abstraction of the chloride ligand by 
the $\mathrm{Na}^{+}$cation created a vacant coordination site that was occupied by a flanking aryl ring of the phosphine. In the rhodium system $\eta^{6}$-arene coordination was preferred, which along with phosphine bonding resulted in a (2+6)-electron binding mode that caused concomitant dissociation of one of the original carbonyl groups and formation of the formally five-coordinate 18 -electron complexes 11·CO.

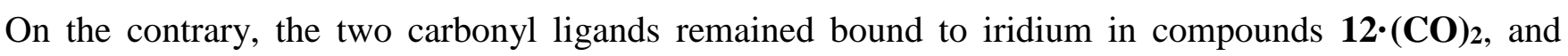
chloride elimination was simply compensated by a $\kappa^{1}-\mathrm{C}_{\text {arene }}$ coordination of a flanking aryl substituent, as occurs in compounds 4 . The dissimilar behaviour of the two systems may reflect once more the higher basicity of $\operatorname{Ir}(\mathrm{I})$ with respect to $\mathrm{Rh}(\mathrm{I})$, resulting in increased back donation to carbonyl ligands and stronger M-CO bonds.

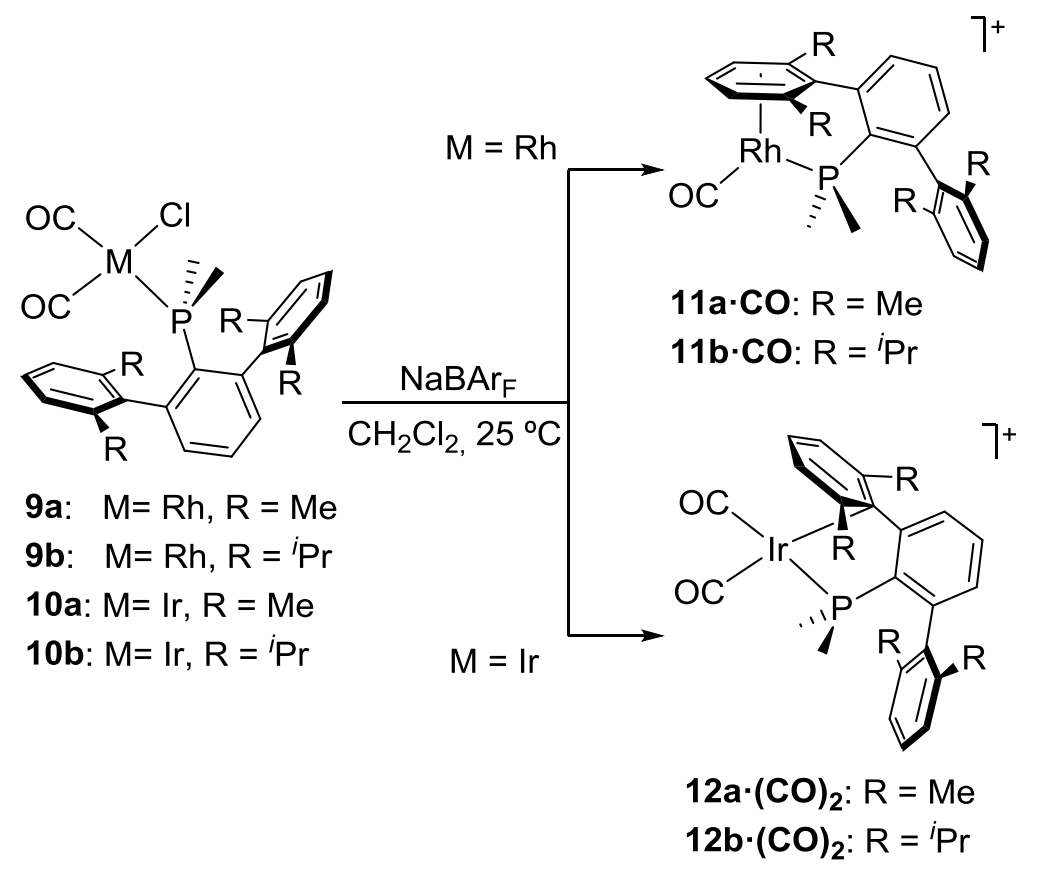

Scheme 6. Synthesis of complexes $\mathbf{1 1} \cdot \mathrm{CO}$ and $\mathbf{1 2} \cdot(\mathrm{CO})_{2}$.

As expected, a single $v(\mathrm{CO})$ intense band at around $2015 \mathrm{~cm}^{-1}$ appears in the IR spectra of compounds 11. CO, while dicarbonyl compounds $\mathbf{1 2} \cdot(\mathbf{C O})_{2}$ are characterized by two strong bands at $c a .2094$ and $2027 \mathrm{~cm}^{-1}$, respectively assigned to the antisymmetric and symmetric stretching vibrations of the $\mathrm{CO}$ groups. The molecular formulation of complexes $\mathbf{1 1} \cdot \mathbf{C O}$ and $\mathbf{1 2} \cdot(\mathbf{C O})_{2}$ was also ascertained by means of NMR spectroscopy. The proposed $\eta^{6}$-coordination of the flanking aryl unit in the rhodium complexes is supported by the comparison of the ${ }^{1} \mathrm{H}$ and ${ }^{13} \mathrm{C}\left\{{ }^{1} \mathrm{H}\right\}$ NMR spectra with those of the related species 2 and 7. In addition, the carbonyl ligand of complexes $\mathbf{1 1} \cdot \mathbf{C O}$ is responsible for a distinctive ${ }^{13} \mathrm{C}$ 
resonance at $183 \mathrm{ppm}\left(\mathrm{dd},{ }^{1} J_{\mathrm{CRh}} \approx 95,{ }^{2} J_{\mathrm{CP}} \approx 18 \mathrm{~Hz}\right)$ while the ${ }^{31} \mathrm{P}\left\{{ }^{1} \mathrm{H}\right\}$ spectrum consists of a doublet at $49.3 \mathrm{ppm}\left({ }^{1} J_{\mathrm{PRh}} \approx 169 \mathrm{~Hz}\right)$. The presence of two carbonyl groups in compounds $\mathbf{1 2} \cdot(\mathbf{C O})_{2}$ is evinced by two resonances at around $183\left(\mathrm{~d},{ }^{2} J_{\mathrm{CP}}=102 \mathrm{~Hz}\right)$ and $163\left(\mathrm{~d},{ }^{2} J_{\mathrm{CP}}=14 \mathrm{~Hz}\right) \mathrm{ppm}$ due respectively to the ligands oriented trans and cis to the phosphine. Distinctive ${ }^{13} \mathrm{C}$ NMR resonances at $c a .118 \mathrm{ppm}\left(\mathrm{d},{ }^{2} J_{\mathrm{CP}}\right.$ $=3 \mathrm{~Hz}$ ) due to the ipso carbon atoms of one of the flanking aryl rings in compounds $\mathbf{1 2} \cdot(\mathbf{C O})_{2}$ are indicative of the existence of a weak $\kappa^{1}$-interaction with the metal to compensate for chloride abstraction. ${ }^{30}$

Complexes 11a $\cdot \mathbf{C O}$ and $\mathbf{1 2 b} \cdot(\mathbf{C O})_{2}$ were also characterized by single crystal X-ray studies (Figure 2). The overall structures are similar to those previously discussed for complexes $\mathbf{2 a}$ and $\mathbf{4 a}$, respectively. The molecules of $\mathbf{1 1 a} \cdot \mathbf{C O}$ have a Rh1—P1 bond essentially identical (2.2338(17) $\AA$ ) to the $\mathrm{Rh}-\mathrm{P}$ bond of $\mathbf{2} \mathbf{a}$ and to that present in related complexes containing $\eta^{6}, \kappa^{1}$-arene-phosphine ligands.10,31 There are some small differences in the $\mathrm{Rh}-\eta^{6}$-arene linkages of complexes $\mathbf{2 a}$ and $\mathbf{1 1 a} \cdot \mathbf{C O}$, as in the latter the $\mathrm{Rh}-\mathrm{C}_{\text {arene }}$ contacts are somewhat longer. Similar to $\mathbf{2 a}$, the $\mathrm{Rh}-\mathrm{C}_{\mathrm{ipso}}$ bond exhibits the shortest separation $(\mathrm{Rh} 1-\mathrm{C} 8=2.163(5) \AA)$, but the remaining $\mathrm{Rh}-\mathrm{C}_{\text {arene }}$ bonds span over the range ca. 2.31$2.39 \AA$. The $\mathrm{Rh}-\mathrm{CO}$ bond features regular metrics $(\mathrm{Rh} 1-\mathrm{C} 1=1.846(6) \AA$; $\mathrm{C} 1-\mathrm{O} 1=1.145(8) \AA)$. The proposed $\kappa^{1}$-coordination of the flanking arene in $\mathbf{1 2 b} \cdot(\mathbf{C O})_{2}$ is confirmed by a short $\operatorname{Ir} 1-\mathrm{C} 7$ contact of 2.297(9) $\AA$ involving the ipso carbon of the $\pi$-aryl group. Similarly to the structure of $\mathbf{4 a}$, this ring is slightly slanted in such a manner that one of the adjacent carbon atoms ( $\operatorname{Ir} 1-\mathrm{C} 8=2.571(4) \AA)$ is closer to the iridium centre than the other one $(\operatorname{Ir} 1-\mathrm{C} 12=2.742(4) \AA) .{ }^{13} \mathrm{C}\left\{{ }^{1} \mathrm{H}\right\}$ NMR data and the noticeable shorter $\mathrm{Ir}-\mathrm{C}_{\text {arene }}$ contact to the ipso carbon already alluded to favour $\kappa^{1}-\mathrm{C}_{\text {arene }}$ coordination, which is further supported by calculations, more precisely by means of the quantum theory of atoms in molecules QTAIM calculations ${ }^{32}$ (see Supporting Information for details).

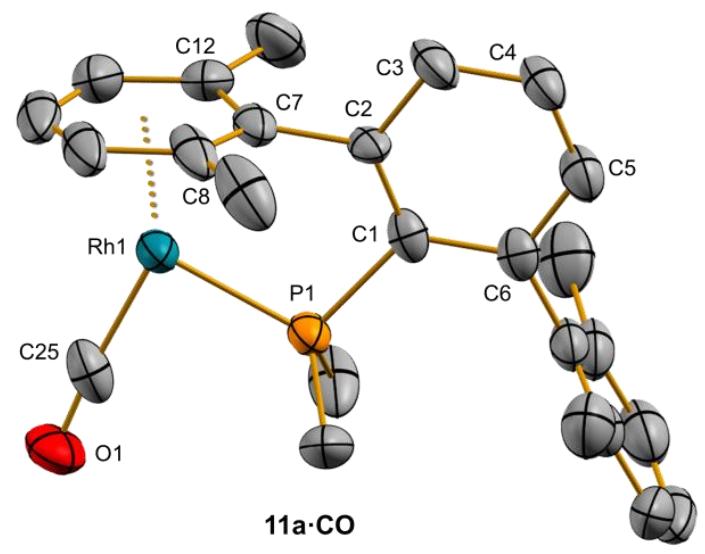




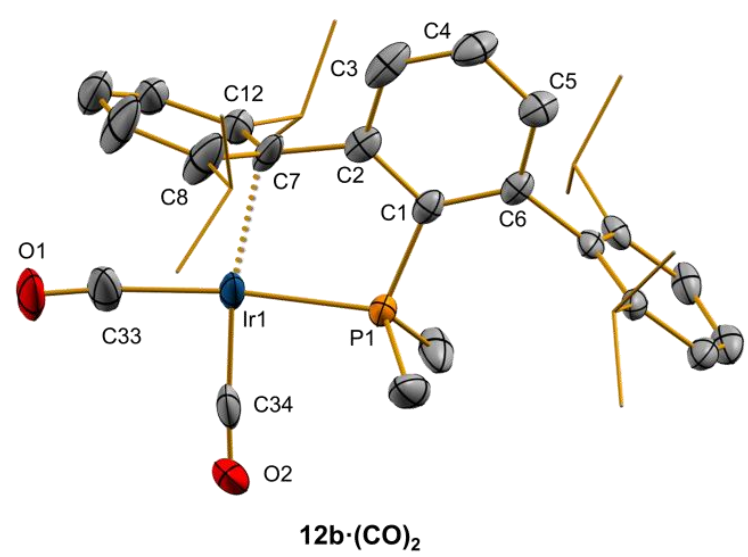

Figure 2. ORTEP view of the cations of complexes $11 \mathbf{a} \cdot \mathbf{C O}$ and $\mathbf{1 2 b} \cdot(\mathbf{C O})_{2}$; hydrogen atoms are excluded and isopropyl groups are represented in wireframe format for clarity, while thermal ellipsoids are set at $50 \%$ level of probability.

Compounds 11. CO were isolated in good yields as air stable orange powders that remained unaltered for long periods of time. Their iridium counterparts, however, underwent in solution an interesting rearrangement of the carbon monoxide ligands. Thus, dichloromethane solutions of compound 12a $\cdot(\mathbf{C O})_{2}$ underwent spontaneous iridium-carbonyl disproportionation to $1: 1$ mixtures of the monocarbonyl species $\mathbf{1 2 a} \cdot \mathbf{C O}$, that is, the iridium version of the aforementioned compound 11a $\mathbf{C O}$, and the tricarbonyl complex $\mathbf{1 2 a} \cdot(\mathbf{C O})_{3}$ (Scheme 7). The reaction was readily monitored by ${ }^{31} \mathrm{P}\left\{{ }^{1} \mathrm{H}\right\}$ NMR spectroscopy. Resonances corresponding to complexes 12a $\mathbf{C O}(6.7 \mathrm{ppm})$ and 12a $(\mathbf{C O}) \mathbf{3}(-20.2$ ppm) gradually appeared shifted to higher fields when compared to $\mathbf{1 2 a} \cdot(\mathbf{C O})_{2}(16.2 \mathrm{ppm})$. Kinetic analysis of this rearrangement revealed a first-order dependence on dicarbonyl compound $\mathbf{1 2 a} \cdot(\mathbf{C O})_{2}$ at room temperature characterized by a first-order rate constant of $2.5 \cdot 10^{-4} \mathrm{~s}^{-1}$, which corresponds to $\Delta \mathrm{G}_{298}^{\ddagger} \approx 22.3 \mathrm{kcal} \cdot \mathrm{mol}^{-1}$ and $t_{1 / 2} \approx 45 \mathrm{~min}$ (see Supporting Information for details). This finding points out to a stepwise mechanism in which $\mathrm{CO}$ dissociation appears to be the rate limiting step. Coordination of the liberated CO to still unreacted $\mathbf{1 2 a} \cdot(\mathbf{C O})_{2}$ would rapidly yield the tricarbonyl species $\mathbf{1 2 a} \cdot(\mathbf{C O})_{3}$. In accordance with this proposal, exposure of dichloromethane solutions of $\mathbf{1 2 a} \cdot(\mathbf{C O})_{2}$ to carbon monoxide (1.2 bar, $25^{\circ} \mathrm{C}$ ) results in immediate and quantitative formation of $\mathbf{1 2 a} \cdot(\mathbf{C O}) 3$. DFT calculations support these findings and show a free energy barrier of $18.3 \mathrm{kcal} \cdot \mathrm{mol}^{-1}$ for $\mathrm{CO}$ dissociation from $12 \mathrm{a} \cdot(\mathbf{C O})_{2}$ to yield $12 \mathrm{a} \cdot \mathbf{C O}$ and $\mathrm{CO}\left(+8.3 \mathrm{kcal} \cdot \mathrm{mol}^{-1}\right)$, which can be captured by 12a $\cdot(\mathbf{C O})_{2}$ through a low barrier of $7.8 \mathrm{kcal} \cdot \mathrm{mol}^{-1}$ to afford $\mathbf{1 2 a} \cdot(\mathbf{C O})_{3}$ (see Figure 4 below and the Supporting Information for details). The latter species is predicted to be the most stable thermodynamically $\left(-9.5 \mathrm{kcal} \cdot \mathrm{mol}^{-1}\right.$ from $\left.\mathbf{1 2 a} \cdot(\mathbf{C O})_{2}+\mathrm{CO}\right)$. 


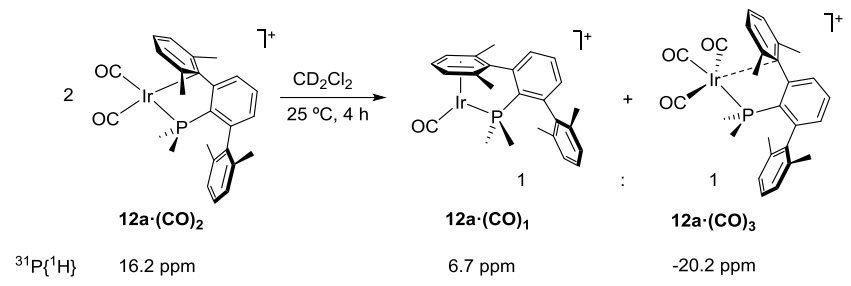

Scheme 7. Solution rearrangement of the carbonyl ligands of complex $\mathbf{1 2 a} \cdot(\mathbf{C O})_{2}$.

Compounds $12 \mathbf{a} \cdot \mathbf{C O}$ and $12 \mathbf{a} \cdot(\mathbf{C O})_{3}$ were synthesized independently (see Experimental Section) and their structures ascertained by spectroscopic methods and X-ray diffraction studies. As expected, compound 12a $\cdot \mathbf{C O}$ exhibits an intense band in its IR spectrum at $2000 \mathrm{~cm}^{-1}$ due to the carbonyl ligand, shifted by almost $20 \mathrm{~cm}^{-1}$ at lower frequency in comparison with the rhodium analog $\mathbf{1 1 a} \cdot \mathbf{C O}$. In turn, tricarbonyl compound 12a· $(\mathbf{C O})_{3}$ gives rise to two bands at 2126 and $2027 \mathrm{~cm}^{-1}$, in agreement with previous compounds of formula $\left[\operatorname{Ir}(\mathrm{CO})_{3} \mathrm{PR}_{3}\right]^{+33}$ Overall, the average bond stretching frequencies for the three iridium compounds depicted in Scheme 7 follow the order $12 a \cdot(\mathrm{CO})_{3}>12 a \cdot(\mathrm{CO})_{2}>12 a \cdot \mathbf{C O}$, in accordance with the distribution of electron density donated by the $\operatorname{Ir}(\mathrm{I})$ centre to the $\pi^{*}$ antibonding orbital of the CO ligands.

The ${ }^{1} \mathrm{H}$ and ${ }^{13} \mathrm{C}\left\{{ }^{1} \mathrm{H}\right\}$ NMR spectra of the new compounds are also in agreement with the proposed formulation. A ${ }^{13} \mathrm{C}\left\{{ }^{1} \mathrm{H}\right\}$ NMR resonance due to the carbonyl ligand in $\mathbf{1 2 a} \cdot \mathbf{C O}$ has been recorded at $167.2 \mathrm{ppm}\left(\mathrm{d},{ }^{2} J_{\mathrm{CP}}=2 \mathrm{~Hz}\right)$, while for compound $\mathbf{1 2 a} \cdot(\mathbf{C O})_{3}$ two signals at $173.1\left(\mathrm{~d},{ }^{2} J_{\mathrm{CP}}=15 \mathrm{~Hz}\right)$ and $168.2\left(\mathrm{~d},{ }^{2} J_{\mathrm{CP}}=88 \mathrm{~Hz}\right) \mathrm{ppm}$ can be assigned to the CO ligands cis and trans to the phosphorus atom. $\eta^{6}-$ Arene coordination in 12a. CO becomes notorious after analysing its ${ }^{1} \mathrm{H}$ and ${ }^{13} \mathrm{C}\left\{{ }^{1} \mathrm{H}\right\}$ NMR data. Moreover, its nature was authenticated by X-ray diffraction studies (Figure 3), which revealed a structure closely similar to that of its rhodium counterpart 11a $\mathbf{C O}$. On the contrary, examination of the spectroscopic data recorded for complex $\mathbf{1 2 a} \cdot(\mathbf{C O})_{3}$ did not provide definitive evidence for the existence of weak interactions with the aryl substituents of the phosphine. ${ }^{30}$ The two flanking aryl rings of the terphenyl fragment appear equivalent at room temperature on the NMR time scale. Nevertheless, 12a $\cdot(\mathbf{C O})_{3}$ exhibits dynamic behaviour in solution due to rapid exchange of the two phosphine aromatic rings, with a coalescence temperature of around $-60{ }^{\circ} \mathrm{C}$ measured in the variable temperature ${ }^{1} \mathrm{H}$ NMR spectrum (see Figure S12 in the Supporting Information). Besides, noticeable exchange peaks were observed in 2D-EXSY experiments. The ${ }^{13} \mathrm{C}\left\{{ }^{1} \mathrm{H}\right\}$ NMR resonance due to the rapidly exchanging ipso carbon atoms of the xylyl substituents appears slightly shielded (132.3 ppm) when compared to non- 
coordinated xylyl rings ( $c$ a. $136 \mathrm{ppm})$. In the solid state, complex 12a·(CO) 3 adopts a distorted square planar geometry, as determined by X-ray diffraction studies. One of the phosphine lateral xylyl rings approaches the metal from an apical position and forces the CO groups cis to the phosphine to bend towards one another, enforcing a distorted trigonal bipyramid arrangement around iridium $\left(\mathrm{OC}_{c i s}-\mathrm{Ir}-\right.$ $\left.\mathrm{CO}_{\text {cis }}=147.17(6)^{\circ}\right)$. The shortest contact between iridium and the proximal xylyl ring occurs through the ipso carbon atom at a distance of 2.523(6) $\AA$ ( $\operatorname{Ir} 1-\mathrm{C} 7)$. This separation, albeit longer than in complexes $12 \mathbf{a} \cdot \mathbf{C O}$ and $\mathbf{1 2 a} \cdot(\mathbf{C O})_{3}$, can be taken as indicative of a weak $\kappa^{1}-\mathrm{C}_{\text {arene }}$ interaction in the solid-state structure. ${ }^{23}$ The DFT-optimized geometry of $\mathbf{1 2 a} \cdot(\mathbf{C O})_{3}$ is consistent with this arrangement, and topological analysis revealed the existence of a bond critical point and a unique bond path between the iridium and the ipso carbon atoms (see SI for details).
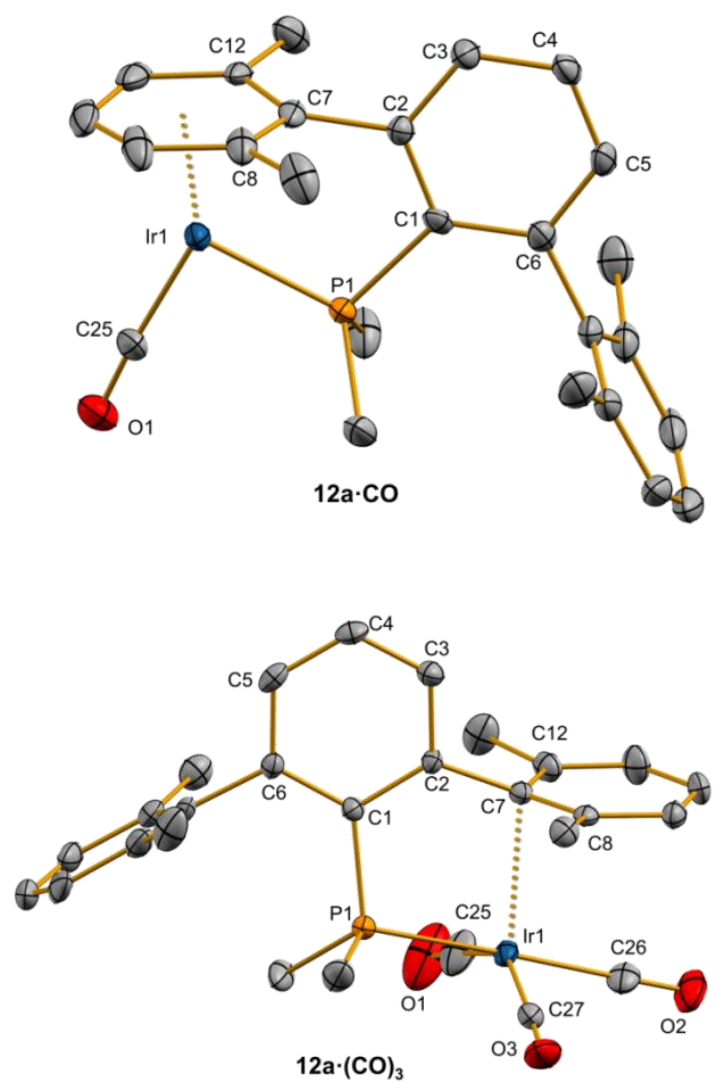

Figure 3. ORTEP view of the cations of complexes $12 \mathbf{a} \cdot \mathbf{C O}$ and $12 \mathbf{a} \cdot(\mathbf{C O})_{3}$; hydrogen atoms are excluded for clarity and thermal ellipsoids are set at $50 \%$ level of probability.

Despite many similarities, the carbon monoxide chemistry of the related iridium system bearing the bulkier $\mathrm{PMe}_{2} \mathrm{Ar}^{\mathrm{Dipp} 2}$ phosphine revealed some subtle differences. For example, when dichloromethane 
solutions of $\mathbf{1 2 b} \cdot(\mathbf{C O})_{2}$ were allowed to stand at room temperature for several days, the only discernible product was the monocarbonyl derivative $\mathbf{1 2 b} \cdot \mathbf{C O}$, even if the reaction

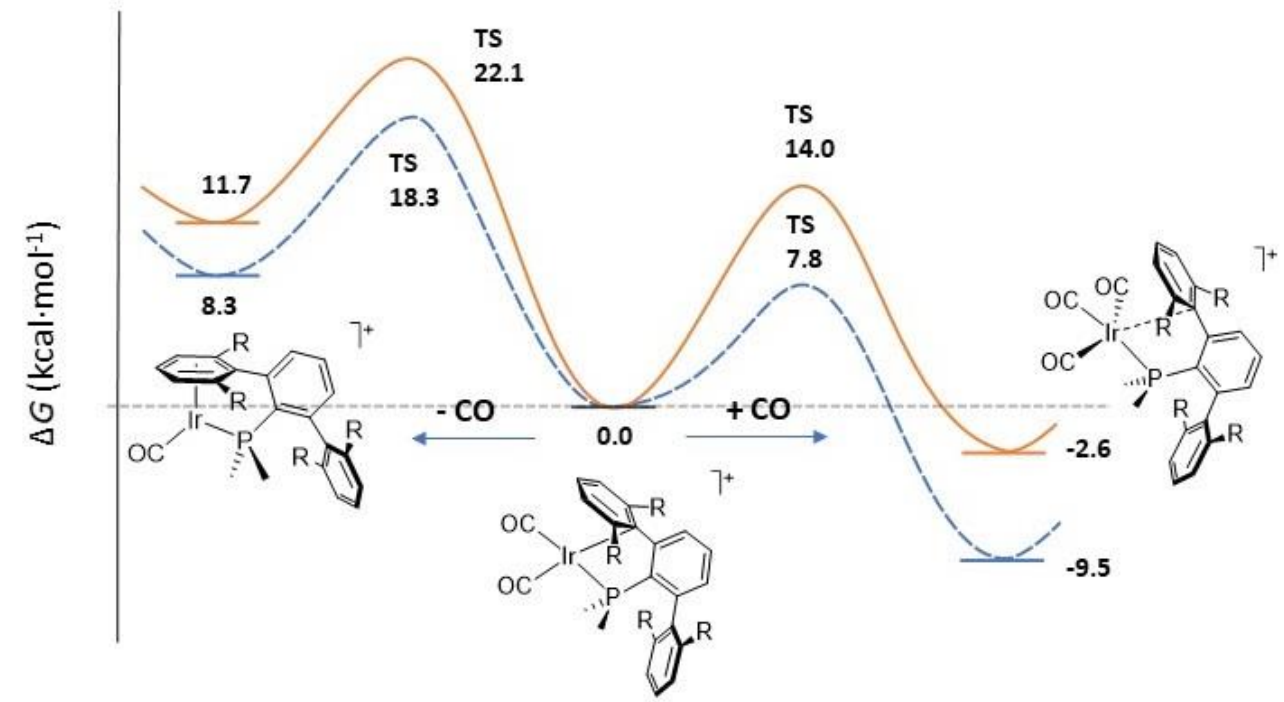

Figure 4. Free energy profile for $\mathrm{CO}$ dissociation and capture in compounds $12 \mathbf{a} \cdot(\mathbf{C O})_{\mathbf{n}}(\mathrm{n}=1-3 ; \mathrm{R}=$

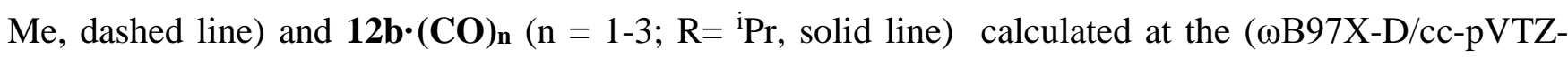
$\mathrm{SDD} / / \omega \mathrm{B} 97 \mathrm{X}-\mathrm{D} / 6-31 \mathrm{G}(\mathrm{d}, \mathrm{p})-\mathrm{SDD})$ level of theory with solvent corrections $\left(\mathrm{SMD}, \mathrm{CH}_{2} \mathrm{Cl}_{2}\right)$. 
was monitored in a sealed NMR tube. It soon became clear that, at variance with the system based on $\mathrm{PMe}_{2} \mathrm{Ar}^{\mathrm{Xyl}}{ }_{2}$, complex 12b· $(\mathbf{C O})_{2}$ is unable to trap at a reasonable rate the carbon monoxide it might eventually dissociate. In support of this, DFT calculations (Figure 4) reveal that CO capture by the latter species has a barrier $6.2 \mathrm{kcal} \cdot \mathrm{mol}^{-1}$ higher than that found for its less hindered counterpart 12a $\cdot(\mathbf{C O})_{2}$. Tricarbonyl complex 12b-(CO) 3 is again predicted by DFT to be the most stable of the three $\mathbf{1 2 b} \cdot(\mathbf{C O})_{\mathbf{n}}$ species $\left(-2.6 \mathrm{kcal} \cdot \mathrm{mol}^{-1}\right.$ from $\left.\mathbf{1 2 b} \cdot(\mathbf{C O})_{2}+\mathrm{CO}\right)$ and could, indeed, be quantitatively prepared by exposure of its mono or dicarbonyl precursors to an excess of $\mathrm{CO}\left(1.2 \mathrm{bar}, \mathrm{CH}_{2} \mathrm{Cl}_{2}, 25^{\circ} \mathrm{C}, 10 \mathrm{~min}\right)$. According to the full spectroscopic characterization (IR and NMR) of these new compounds, their structures are analogous to those depicted in Scheme 7. The chemical formulation of compound 12b. CO was further verified by single crystal X-ray studies. The geometric features determined are essentially alike those in the related xylyl phosphine system (see Figure S9). Regarding complex $\mathbf{1 2 b} \cdot(\mathbf{C O})_{3}$, variable temperature NMR studies evidenced a fluxional behaviour similar to that discussed above for $12 \mathbf{a} \cdot(\mathbf{C O})_{3}$, with a nearly identical coalescence temperature. In this case, the DFT-optimized geometry of $12 \mathbf{b} \cdot(\mathbf{C O})_{3}$ is distorted from that of $12 \mathbf{a} \cdot(\mathbf{C O})_{3}$, probably due to steric hindrance between the isopropyl substituents and the carbonyl groups, shifting the closest $\mathrm{Ir}-\mathrm{C}_{\text {arene }}$ interaction to the ortho carbon (see SI for details). Monitoring the evolution of $\mathbf{1 2 b} \cdot(\mathbf{C O})_{2}$ by ${ }^{31} \mathrm{P}\left\{{ }^{1} \mathrm{H}\right\}$ NMR spectroscopy at 25 ${ }^{\circ} \mathrm{C}$ provided kinetic information for the formation of monocarbonyl species $\mathbf{1 2 b} \cdot \mathbf{C O}\left(\mathrm{k}_{1}=1.2 \cdot 10^{-5} \mathrm{~s}^{-1}\right.$, $\Delta \mathrm{G}_{298}^{\ddagger} \approx 24.1 \mathrm{kcal} \cdot \mathrm{mol}^{-1}, t_{1 / 2} \approx 16 \mathrm{~h}$; see SI for details), clearly reflecting the slower dissociation rate of carbon monoxide when compared to the system constructed around $\mathrm{PMe}_{2} \mathrm{Ar}^{\mathrm{Xyl}_{2}}\left(22.1 \mathrm{vs} .18 .3 \mathrm{kcal} \cdot \mathrm{mol}^{-}\right.$ 1 according to the calculations).

To complete these studies we decided to explore whether the analogous cationic carbonyl rhodium compounds would exhibit similar rearrangement chemistry. Although exposure of complexes $\mathbf{1 1} \cdot \mathbf{C O}$ to 1 bar of carbon monoxide did not result in the formation of the expected tricarbonyl compounds, some interesting observations were disclosed when somewhat higher CO pressures (6 bar) were employed. The chemical changes were monitored by ${ }^{1} \mathrm{H},{ }^{31} \mathrm{P}\left\{{ }^{1} \mathrm{H}\right\}$ and ${ }^{13} \mathrm{C}\left\{{ }^{1} \mathrm{H}\right\}$ NMR spectroscopy at variable temperature (from 25 to $-60^{\circ} \mathrm{C}$ ) and are summarized in Scheme 8. As can be seen, attainment of a fast equilibrium on the laboratory time scale between the starting monocarbonyl complex $\mathbf{1 1} \cdot \mathbf{C O}$ and tricarbonyl species $\mathbf{1 1} \cdot(\mathbf{C O})_{3}$ is proposed. Naturally, equilibria of this type are temperature dependent, with low temperatures disfavouring $\mathrm{CO}$ dissociation from $\mathbf{1 1} \cdot(\mathbf{C O})_{3}$ and formation of the monocarbonyl compounds $\mathbf{1 1} \cdot \mathbf{C O}$, which exhibit in addition full phosphine chelation, i. e. $\kappa^{1}-\mathrm{P}: \eta^{6}$-arene coordination of the terphenyl phosphine ligand. The variable temperature ${ }^{13} \mathrm{C}\left\{{ }^{1} \mathrm{H}\right\}$ NMR studies to be discussed next back strongly this proposal. Likewise, variable temperature ${ }^{31} \mathrm{P}\left\{{ }^{1} \mathrm{H}\right\}$ NMR experiments using complex 11a. $\mathrm{CO}$ are also in accordance with the equilibrium represented in Scheme 8 and reveals besides that the tricarbonyl derivative exists in equilibrium with minor concentrations of a closely related complex. This equilibrium is fast on the NMR time scale and can only be frozen at temperatures below $-50{ }^{\circ} \mathrm{C}$ 
(Figure S11). It is important to mention that removal of $\mathrm{CO}$ under vacuum displaces the equilibrium of Scheme 8 toward the left, allowing quantitative recovery of the monocarbonyls $\mathbf{1 1} \cdot \mathbf{C O}$.

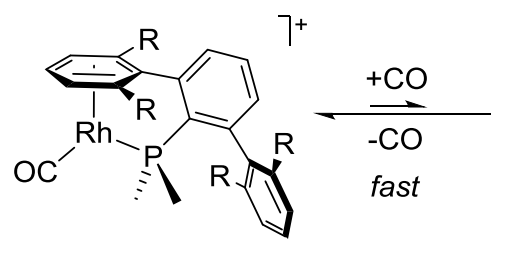

11a.CO: $R=M e \quad 65: 35$

11b·CO: $\mathrm{R}={ }^{i} \mathrm{Pr}$

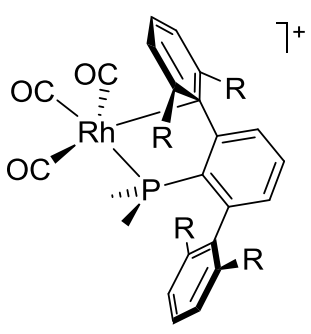

11a. $(\mathrm{CO})_{3}: \mathrm{R}=\mathrm{Me}$ 11b.(CO) $)_{3}: \mathrm{R}={ }^{i} \mathrm{Pr}$

Scheme 8. Solution equilibria between complexes $\mathbf{1 1} \cdot \mathbf{C O}$ and $\mathbf{1 1} \cdot(\mathbf{C O})_{3}$ under a $\mathrm{CO}$ atmosphere $(6$ bar, $\mathrm{CD}_{2} \mathrm{Cl}_{2}, 25^{\circ} \mathrm{C}$ to $\left.-60{ }^{\circ} \mathrm{C}\right)$.

Figure 5 contains ${ }^{13} \mathrm{C}\left\{{ }^{1} \mathrm{H}\right\}$ NMR spectra of $\mathrm{CD}_{2} \mathrm{Cl}_{2}$ solutions of complex 11a· $(\mathbf{C O})_{1}$ recorded at $25,-40$ and $-60{ }^{\circ} \mathrm{C}$, under 6 bar of CO. For the sake of simplicity only the most informative carbonyl and aliphatic regions of the spectrum are shown (roughly 185-176 and 24-16 ppm, respectively). With reference to the room temperature spectrum, the monocarbonyl $\mathbf{1 1 a} \cdot \mathbf{C O}$ exhibits the expected doubletof-doublet carbonyl resonance centred at $183.2 \mathrm{ppm}$, a $\mathrm{PMe}_{2}$ doublet signal at $19.1 \mathrm{ppm}\left(\mathrm{d},{ }^{1} J_{\mathrm{CP}}=37\right.$ $\mathrm{Hz})$ and $\mathrm{Me}(\mathrm{Xyl})$ singlets with $\delta 22.0$ and $20.3 \mathrm{ppm}$. In addition, there is a broad hump centred at $c a$. $182.1 \mathrm{ppm}$ and a singlet at $22.4 \mathrm{ppm}$ that are attributed to the $\mathrm{CO}$ ligands and $M e(\mathrm{Xyl})$ groups, respectively, of the purported tricarbonyl $11 a \cdot(\mathbf{C O})_{3}$. The signal due to the $\mathrm{PMe}_{2}$ groups of the phosphine is very broad and can be conjectured to be located at $19.5 \mathrm{ppm}$, practically hidden into the base-line. Upon cooling, this signal becomes clearly discernible and appears at $18.5 \mathrm{ppm}\left(\mathrm{d},{ }^{1} J_{\mathrm{CP}}=37\right.$ $\mathrm{Hz}$ ) in the $-60^{\circ} \mathrm{C}$ spectrum. At the latter temperature, the broad signal of the $\mathrm{CO}$ ligands of $\mathbf{1 1 a} \cdot(\mathbf{C O})_{3}$ centred at $c a$. $182.1 \mathrm{ppm}$, resolves into two doublet-of-doublet resonances in a ca. 2:1 ratio, observed at $180.6\left({ }^{1} J_{\mathrm{CRh}}=69,{ }^{2} J_{\mathrm{CP}}=16 \mathrm{~Hz}\right)$ and $178.8 \mathrm{ppm}\left({ }^{1} J_{\mathrm{CRh}}=51,{ }^{2} J_{\mathrm{CP}}=92 \mathrm{~Hz}\right)$, attributable respectively to two cis and one trans carbonyl groups, relative to the phosphine ligand. The low ratio of the $\mathrm{PMe}_{2} \mathrm{Ar}^{\text {Dipp2 }}$ complex $\mathbf{1 1 b} \cdot(\mathbf{C O})_{3}\left(<5 \%\right.$ at $\left.-60{ }^{\circ} \mathrm{C}\right)$ precluded performing a similar analysis based on ${ }^{13} \mathrm{C}$ NMR spectroscopy.

In turn, the room temperature ${ }^{31} \mathrm{P}\left\{{ }^{1} \mathrm{H}\right\}$ NMR spectrum (Figure S11) shows a sharp doublet for 11a・ CO with 849.3 , along with a broad signal centred at about $-2.30 \mathrm{ppm}$. Upon cooling, the latter resonance 
becomes gradually resolved, and at $-60^{\circ} \mathrm{C}$ it converts into a main doublet resonance at $-1.21 \mathrm{ppm}\left({ }^{1} J_{\mathrm{PRh}}=\right.$ $91 \mathrm{~Hz}$ ) that can be reasonably attributed to $\mathbf{1 1 a} \cdot(\mathbf{C O})_{3}$ (Scheme 8), along with a considerably less intense doublet at $-3.6 \mathrm{ppm}$, exhibiting a one-bond ${ }^{31} \mathrm{P}-{ }^{103} \mathrm{Rh}$ coupling constant of $117 \mathrm{~Hz}$. In the meantime, the $49.3 \mathrm{ppm}$ doublet featuring a ${ }^{1} J_{\mathrm{PRh}}$ coupling constant of $167 \mathrm{~Hz}$ remains unchanged (Figure S11).

Although by similarity with the analogous iridium system it may be tempting to propose that the less intense, lowest frequency doublet registered at $-2.30 \mathrm{ppm}$ could be due to small concentrations of a dicarbonyl species $11 \mathbf{a} \cdot(\mathbf{C O})_{2}$ related to the iridium complex $12 \mathbf{a} \cdot(\mathbf{C O})_{2}$ of Scheme 7 , the close correspondence of the NMR parameters found for the major and minor, rapidly interchanging species, suggest instead that they feature comparable molecular complexity. For all compounds investigated in this work, implication of a lateral aryl group of the terphenyl radical in the bonding to the metal centre causes deshielding of the ${ }^{31} \mathrm{P}\left\{{ }^{1} \mathrm{H}\right\}$ NMR resonance. On this basis we suggest that the more intense doublet at $-1.21 \mathrm{ppm}$ may be due to complex $\mathbf{1 1 a} \cdot(\mathbf{C O}) 3$ with bidentate phosphine binding through the phosphorus and one of the ipso carbon atoms of the terpehenyl substituent, whereas the signal with reduced intensity, slightly shifted to lower frequency $(-3.6 \mathrm{ppm})$, corresponds to an isomeric fourcoordinate complex in which the phosphine behaves as a monodentate ligand through the $\mathrm{P}$ atom.

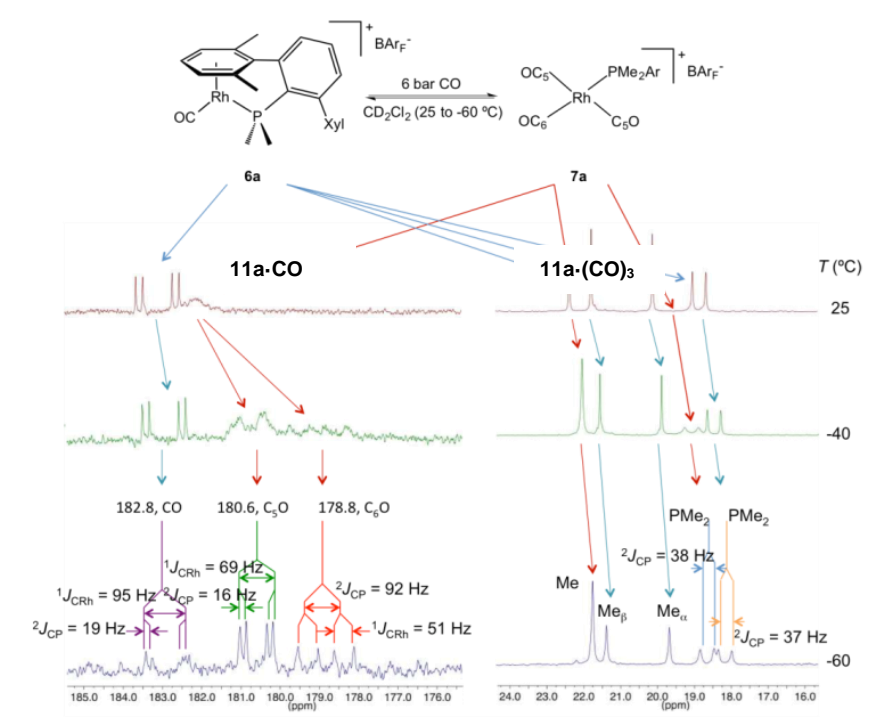

Figure 5. Variable temperature ${ }^{13} \mathrm{C}\left\{{ }^{1} \mathrm{H}\right\}$ NMR spectra, in the carbonyl and aliphatic regions, of complex 11a. $\mathrm{CO}$ under 6 bar of $\mathrm{CO}\left(100 \mathrm{MHz}, \mathrm{CD}_{2} \mathrm{Cl}_{2},-60{ }^{\circ} \mathrm{C}\right.$ to $\left.25^{\circ} \mathrm{C}\right)$.

\section{Conclusions}

The reactivity found out for the reported $\operatorname{Rh}(\mathrm{I})$ and $\operatorname{Ir}(\mathrm{I})$ complexes of dialkylterphenyl phosphines, $\mathrm{PMe}_{2} \mathrm{Ar}$ ', such as $\mathrm{PMe}_{2} \mathrm{Ar}^{\mathrm{Xyl}}{ }_{2}$ and $\mathrm{PMe}_{2} \mathrm{Ar}^{\mathrm{Dipp}}$, demonstrates the coordination adaptability of this still 
understudied family of ligands, which can be viewed as hemilabiles because of the active binding function exerted by one of their flanking aryl rings. Besides classical $\kappa^{1}-\mathrm{P}$ coordination, the molecules of $\mathrm{PMe}_{2} \mathrm{Ar}$ ' can behave as bidentate, $\mathrm{L}_{2}$, 4-electron donors in the $\kappa^{1}-\mathrm{P}: \kappa^{1}-\mathrm{C}_{\text {arene }}$ bonding mode demonstrated by X-ray crystallography for complexes $\mathbf{4 a}, \mathbf{1 2 b}$ and $\mathbf{1 2 a} \cdot(\mathbf{C O})_{3}$. Likewise, formally tetradentate $\kappa^{1}-P: \eta^{6}$-arene coordination as $\mathrm{L}_{4}$ ligands is also readily attainable, as for instance in $\mathbf{2 a}$, 11a. CO and $12 \mathbf{a} \cdot \mathbf{C O}$.

Our experimental and computational work also proves that changes from one coordination mode to a different one can be triggered by simple variations in the binding mode of other ligands, as in the equilibria represented in Scheme 3, or by ligand association or dissociation, e. g. Scheme 8. It therefore becomes apparent that terphenyl phosphines possess the potential to stabilize, through weak $\pi$ interactions, low-coordinate intermediates which could play a crucial function in catalysis. We are currently exploring some catalytic applications of late transition metal complexes of terphenyl phosphine ligands and pursuing the synthesis of even bulkier and stronger electron-releasing $\mathrm{PR}_{2} \mathrm{Ar}^{\prime}$ ligands, featuring more sterically demanding alkyl substituents $\left(\mathrm{R}=\mathrm{Et}, i\right.$-Pr, $c-\mathrm{C}_{5} \mathrm{H}_{9}, c-\mathrm{C}_{6} \mathrm{H}_{11}$ and others).

\section{Experimental Section}

General: All preparations and manipulations were carried out under oxy-gen-free nitrogen unless otherwise stated, using conventional Schlenk techniques and, when specified, at low temperature. Solvents were rigorously dried and degassed before use. Solution NMR spectra were recorded on Bruker Avance DPX-300, Avance DRX-400, Avance DRX-500, and 400 Ascend/R spectrometers. The ${ }^{1} \mathrm{H}$ and ${ }^{13} \mathrm{C}$ resonances of the solvent were used as the internal standard and the chemical shifts are reported relative to TMS. $[\mathrm{RhCl}(\mathrm{COD})]_{2}, \quad\left[\mathrm{RhCl}\left(\mathrm{C}_{2} \mathrm{H}_{4}\right)_{2}\right]_{2}, \quad[\operatorname{IrCl}(\mathrm{COD})]_{2}, \quad\left[\operatorname{IrCl}(\mathrm{COE})_{2}\right]_{2}{ }^{\text {xxxiv }}$,

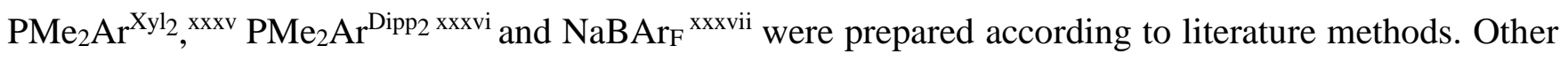
chemicals were commercially available and used as received. CCDC nos. 1819716-1819722 contain the supplementary crystallographic data for compounds $\mathbf{2 a}, \mathbf{7 b}, \mathbf{1 1 a} \cdot(\mathbf{C O})_{\mathbf{1}}, \mathbf{1 2 a} \cdot(\mathbf{C O})_{\mathbf{1}}, \mathbf{1 2 a} \cdot(\mathbf{C O})_{\mathbf{3}}$, 12b·(CO)1 and 12b·(CO)2, and CCDC no. 1820681 for compound 4a. These data can be obtained free of charge from The Cambridge Crystallographic Data Centre via www.ccdc.cam.ac.uk/data_request/cif.

[Rh(cod)PMe2Ar'][BArF] (2): To a solid mixture of complex $1(0.08 \mathrm{mmol})$ and $\mathrm{NaBAr}_{\mathrm{F}}(0.08 \mathrm{mmol})$, placed in a thick-wall ampoule, was added $5 \mathrm{~mL}$ of $\mathrm{CH}_{2} \mathrm{Cl}_{2}$. The resulting solution was stirred for 10 min at room temperature, filtered and the volatiles evaporated under reduced pressure to obtain complex 2 as an orange (a) or yellow (b) powder in $c a$. 90\% yield. This species can be recrystallized by slow diffusion of pentane into a $\mathrm{CH}_{2} \mathrm{Cl}_{2}$ solution at $-20{ }^{\circ} \mathrm{C}$. 2a: Anal. Calc. for $\mathrm{C}_{64} \mathrm{H}_{51} \mathrm{BF}_{24} \mathrm{PRh}$ : C, 54.1; $\mathrm{H}$, 3.6. Found: C, 54.4; H, 3.4. ${ }^{1} \mathrm{H}$ NMR (400 MHz, $\left.25^{\circ} \mathrm{C}, \mathrm{CD}_{2} \mathrm{Cl}_{2}\right)$ \&: $7.82\left(p-\mathrm{C}_{6} \mathrm{H}_{3}(\mathrm{COSY})\right), 7.57$ (br, $1 \mathrm{H}$, 
$m^{\prime}-\mathrm{C}_{6} \mathrm{H}_{3}$ ), 7.30 (br, 1H, m- $\mathrm{C}_{6} \mathrm{H}_{3}$ ), 7.20 (br, 2H, m-Xyl), 6.80 (br, 2H, m-Xyl'), 5.88 (br, 1H, p-Xyl'), 5.53 (br, 2H, $\mathrm{CH}_{\mathrm{cod}}$ ), 3.44 (s, 2H, $\mathrm{RhCH}_{\mathrm{cod}}$ ), 2.44 (m, 4H, $\mathrm{CH}_{2 \mathrm{cod}}$ ), 2.10 (m, 4H, $\mathrm{CH}_{2 \mathrm{cod}}$ ), 2.16 (s, 6H, $\left.\mathrm{MeXyl}^{\prime}\right), 2.01(\mathrm{~s}, 6 \mathrm{H}, \mathrm{Mexyl}), 1.23\left(\mathrm{~d}, 6 \mathrm{H},{ }^{2} J_{\mathrm{HP}}=11.3 \mathrm{~Hz}, \mathrm{PMe}_{2}\right) .{ }^{1} \mathrm{H} \mathrm{NMR}\left(400 \mathrm{MHz}, 0{ }^{\circ} \mathrm{C}, \mathrm{CD}_{2} \mathrm{Cl}_{2}\right) \delta$ : $7.81\left(p-\mathrm{C}_{6} \mathrm{H}_{3}(\mathrm{COSY})\right), 7.59\left(\mathrm{~m}, 1 \mathrm{H}, m^{\prime}-\mathrm{C}_{6} \mathrm{H}_{3}\right), 7.30\left(\mathrm{t},{ }^{3} J_{\mathrm{HH}}=7.5 \mathrm{~Hz}, 1 \mathrm{H}, p-\mathrm{Xyl}\right), 7.27\left(\mathrm{dd},{ }^{3} J_{\mathrm{HH}}=7.4\right.$ $\left.\mathrm{Hz},{ }^{4} J_{\mathrm{HP}}=3.0 \mathrm{~Hz}, 1 \mathrm{H}, m-\mathrm{C}_{6} \mathrm{H}_{3}\right), 7.18\left(\mathrm{~d},{ }^{3} J_{\mathrm{HH}}=7.5 \mathrm{~Hz}, 2 \mathrm{H}, m-\mathrm{Xyl}\right), 6.75\left(\mathrm{~d},{ }^{3} J_{\mathrm{HH}}=6.4 \mathrm{~Hz}, 2 \mathrm{H}, m^{-}\right.$ Xyl'), 5.81 (m, 1H, p-Xyl'), 5.55 (m, 2H, $\left.\mathrm{CH}_{\text {cod }}\right), 3.38$ (m, 2H, $\left.\mathrm{RhCH}_{\mathrm{cod}}\right), 2.43$ (m, 4H, $\left.\mathrm{CH}_{2 \mathrm{cod}}\right), 2.07$ (m, 4H, $\mathrm{CH}_{2 \mathrm{cod}}$ ), 2.13 (s, 6H, Mexyl'), 1.98 (s, 6H, Mexyl), $1.20\left(\mathrm{~d},{ }^{2} J_{\mathrm{HP}}=11.3 \mathrm{~Hz}, 6 \mathrm{H}, \mathrm{PMe}_{2}\right) .{ }^{13} \mathrm{C}\left\{{ }^{1} \mathrm{H}\right\}$ NMR $\left(100 \mathrm{MHz},-10{ }^{\circ} \mathrm{C}, \mathrm{CD}_{2} \mathrm{Cl}_{2}\right) \delta: 146.8\left(o-\mathrm{C}_{6} \mathrm{H}_{3}\right), 142.6\left(\mathrm{~d},{ }^{2} J_{\mathrm{CP}}=21 \mathrm{~Hz}, o-\mathrm{C}_{6} \mathrm{H}_{3}\right), 137.8\left(\mathrm{~d},{ }^{1} J_{\mathrm{CP}}=\right.$ $50 \mathrm{~Hz}$, ipso- $\left.\mathrm{C}_{6} \mathrm{H}_{3}\right), 137.8$ (ipso-Xyl), 136.3 (o-Xyl), $133.5\left(p-\mathrm{C}_{6} \mathrm{H}_{3}\right), 132.3\left(\mathrm{~d},{ }^{3} J_{\mathrm{CP}}=6 \mathrm{~Hz}, m-\mathrm{C}_{6} \mathrm{H}_{3}\right)$, $132.3\left(\mathrm{CH}_{\mathrm{cod}}\right), 128.6$ (p-Xyl), 127.8 (m-Xyl), 127.7 (d, $\left.{ }^{3} J_{\mathrm{CP}}=15 \mathrm{~Hz}, m^{\prime}-\mathrm{C}_{6} \mathrm{H}_{3}\right), 120.5$ (o-Xyl'), 116.1 (ipso-Xyl'), $112.1\left(m-\mathrm{Xyl}^{\prime}\right), 97.1\left(\mathrm{~d},{ }^{2} J_{\mathrm{CP}}=10 \mathrm{~Hz}, p\right.$-Xyl'), $74.0\left(\mathrm{~d},{ }^{1} J_{\mathrm{CRh}}=13 \mathrm{~Hz}, \mathrm{RhCH}_{\mathrm{cod}}\right), 35.1$ $\left(\mathrm{CH}_{2 \mathrm{cod}}\right), 31.7\left(\mathrm{CH}_{2 \mathrm{cod}}\right), 21.1(\mathrm{Mexyl}), 19.5(\mathrm{Mexyl}), 13.6\left(\mathrm{~d},{ }^{1} J_{\mathrm{CP}}=33 \mathrm{~Hz}, \mathrm{PMe}_{2}\right) .{ }^{31} \mathrm{P}\left\{{ }^{1} \mathrm{H}\right\} \mathrm{NMR}(160$ $\left.\mathrm{MHz},-10{ }^{\circ} \mathrm{C}, \mathrm{CD}_{2} \mathrm{Cl}_{2}\right) \delta: 48.1\left(\mathrm{~d},{ }^{1} J_{\mathrm{PRh}}=192 \mathrm{~Hz}\right.$ ). 2b: Anal. Calc. for $\mathrm{C}_{72} \mathrm{H}_{67} \mathrm{BF}_{24} \mathrm{PRh}: \mathrm{C}, 56.41 ; \mathrm{H}$,

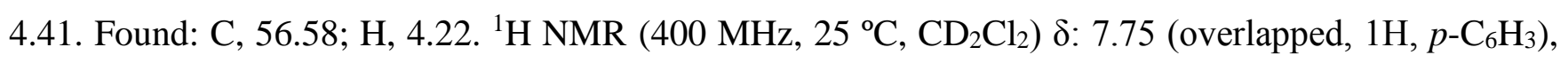
$7.73(\mathrm{~s}, 8 \mathrm{H}, o-\mathrm{Ar}), 7.64\left(\mathrm{br} \mathrm{d},{ }^{3} J_{\mathrm{HH}}=7.6 \mathrm{~Hz}, 1 \mathrm{H}, m^{\prime}-\mathrm{C}_{6} \mathrm{H}_{3}\right), 7.57(\mathrm{~s}, 4 \mathrm{H}, p-\mathrm{Ar}), 7.45\left(\mathrm{t},{ }^{3} J_{\mathrm{HH}}=7.8 \mathrm{~Hz}\right.$, $1 \mathrm{H}, p$-Dipp), $7.39\left(\mathrm{ddd},{ }^{3} J_{\mathrm{HH}}=7.6 \mathrm{~Hz},{ }^{4} J_{\mathrm{HP}}=3.3 \mathrm{~Hz},{ }^{4} J_{\mathrm{HH}}=1.1 \mathrm{~Hz}, 1 \mathrm{H}, m-\mathrm{C}_{6} \mathrm{H}_{3}\right), 7.27\left(\mathrm{~d},{ }^{3} J_{\mathrm{HH}}=7.8\right.$ $\mathrm{Hz}, 2 \mathrm{H}, m$-Dipp), 6.76 (d, ${ }^{3} J_{\mathrm{HH}}=6.8 \mathrm{~Hz}, 2 \mathrm{H}, m$-Dipp'), 6.00 (br t $,{ }^{3} J_{\mathrm{HH}}=6.8 \mathrm{~Hz}, 1 \mathrm{H}, p$-Dipp'), 5.54 (br s, 2H, $\mathrm{CH}_{\text {cod }}$ ), 3.38 (br s, 2H, $\left.\mathrm{RhCH}_{\text {cod }}\right), 2.41$ (m, 4H, $\left.\mathrm{CH}_{2 \mathrm{cod}}\right), 2.24\left(\mathrm{~m}, 2 \mathrm{H},\left(\mathrm{CHMe}_{2}\right)_{\text {Dipp }}\right), 2.22$ (m, 2H, $\left.\left(\mathrm{CHMe}_{2}\right)_{\text {Dipp }}\right), 2.05$ (m, 4H, $\left.\mathrm{CH}_{2 \mathrm{cod}}\right), 1.36\left(\mathrm{~d},{ }^{3} \mathrm{~J}_{\mathrm{HH}}=6.9 \mathrm{~Hz}, 6 \mathrm{H}, \mathrm{Me}_{\text {Dipp }}\right), 1.23$ (m, 6H, Me $\left.\mathrm{Dipp}\right), 1.22(\mathrm{~m}$, $\left.6 \mathrm{H}, \mathrm{Me}_{\mathrm{Dipp}}\right), 1.14\left(\mathrm{dd},{ }^{2} J_{\mathrm{HP}}=11.3 \mathrm{~Hz},{ }^{3} J_{\mathrm{HRh}}=1.3 \mathrm{~Hz}, \mathrm{PMe}_{2}\right), 1.00\left(\mathrm{~d},{ }^{3} J_{\mathrm{HH}}=6.6 \mathrm{~Hz}, 6 \mathrm{H}, \mathrm{Me}_{\mathrm{Dipp}}\right)$. ${ }^{13} \mathrm{C}\left\{{ }^{1} \mathrm{H}\right\} \mathrm{NMR}\left(100 \mathrm{MHz}, 25^{\circ} \mathrm{C}, \mathrm{CD}_{2} \mathrm{Cl}_{2}\right) \delta: 162.2$ (q, ${ }^{1} J_{\mathrm{CB}}=50 \mathrm{~Hz}$, ipso-Ar), 147.1 (o-Dipp), 145.3 (o$\left.\mathrm{C}_{6} \mathrm{H}_{3}\right), 141.9\left(\mathrm{~d},{ }^{2} J_{\mathrm{CP}}=21 \mathrm{~Hz}, o-\mathrm{C}_{6} \mathrm{H}_{3}\right), 140.0\left(\mathrm{~d},{ }^{1} J_{\mathrm{CP}}=51 \mathrm{~Hz}\right.$, ipso- $\left.\mathrm{C}_{6} \mathrm{H}_{3}\right), 135.5$ (ipso-Dipp), 135.2 (oAr), $134.2\left(\mathrm{~d},{ }^{3} J_{\mathrm{CP}}=6 \mathrm{~Hz}, m-\mathrm{C}_{6} \mathrm{H}_{3}\right), 132.0\left(p-\mathrm{C}_{6} \mathrm{H}_{3}\right), 130.6$ (p-Dipp), $129.6\left(\mathrm{br}, \mathrm{CH}_{\mathrm{cod}}\right), 129.3\left(\mathrm{q},{ }^{2} J_{\mathrm{CF}}=\right.$ $31 \mathrm{~Hz}, m$-Ar), 128.6 (d, $\left.{ }^{3} J_{\mathrm{CP}}=15 \mathrm{~Hz}, m^{\prime}-\mathrm{C}_{6} \mathrm{H}_{3}\right), 127.8$ (br, o-Dipp'), 125.0 (q, ${ }^{1} J_{\mathrm{CF}}=272 \mathrm{~Hz}, \mathrm{CF}_{3}$ ), 123.6 (m-Dipp), 117.9 (m, p-Ar), 113.0 (br, ipso-Dipp'), 108.9 (br, m-Dipp’), 99.2 (br, p-Dipp'), 74.7 (d, $\left.{ }^{1} J_{\mathrm{CRh}}=13 \mathrm{~Hz}, \mathrm{RhCH}_{\mathrm{cod}}\right), 35.7\left(\mathrm{CH}_{2 \mathrm{cod}}\right), 31.9\left(\mathrm{CH}_{2 \mathrm{cod}}\right), 31.6\left(\left(C \mathrm{HMe}_{2}\right)_{\text {Dipp }}\right), 30.1\left(\left(C \mathrm{HMe}_{2}\right)_{\text {Dipp }}\right), 26.3$

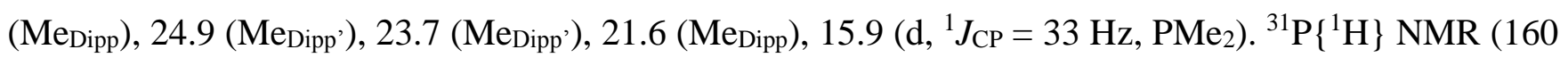
$\left.\mathrm{MHz}, 25^{\circ} \mathrm{C}, \mathrm{CD}_{2} \mathrm{Cl}_{2}\right) \delta: 48.4\left(\mathrm{br} \mathrm{d},{ }^{1} J_{\mathrm{PRh}}=192 \mathrm{~Hz}\right)$.

[Ir(cod)PMe2Ar'][BArF] (4,5): To a solid mixture of complex $3(0.07 \mathrm{mmol})$ and $\operatorname{NaBAr}_{\mathrm{F}}(0.07$ mmol), placed in a thick-wall ampoule, was added $5 \mathrm{~mL}$ of $\mathrm{CH}_{2} \mathrm{Cl}_{2}$. The resulting solution was stirred for $10 \mathrm{~min}$ at room temperature, filtered and the volatiles evaporated under reduced pressure to obtain $\left[\operatorname{Ir}(\mathrm{cod}) \mathrm{PMe}_{2} \mathrm{Ar}^{\prime}\right]\left[\mathrm{BAr}_{\mathrm{F}}\right](\mathbf{4 , 5})$ as a red $(\mathbf{a})$ or orange $(\mathbf{b})$ powder in ca. $85 \%$ yield. Single crystals were grown from a saturated hexane-dichloromethane solution. 4a,5a: Anal. Calcd. for $\mathrm{C}_{64} \mathrm{H}_{51} \mathrm{BF}_{24} \mathrm{IrP}$ : $\mathrm{C}$, 50.91; H, 3.40. Found: C, 50.61; H, 3.70. 4a: ${ }^{1} \mathrm{H}$ NMR $\left(400 \mathrm{MHz},-15{ }^{\circ} \mathrm{C}, \mathrm{CD}_{2} \mathrm{Cl}_{2}\right) \delta: 7.60\left(\mathrm{td},{ }^{3} J_{\mathrm{HH}}=\right.$ 
$\left.7.6 \mathrm{~Hz},{ }^{5} J_{\mathrm{HP}}=2.3 \mathrm{~Hz}, 1 \mathrm{H}, p-\mathrm{C}_{6} \mathrm{H}_{3}\right), 7.41$ to 7.16 (br and overlapped, $\left.6 \mathrm{H}, m-\mathrm{Xyl}, p-\mathrm{Xyl}\right), 7.15$ ( $m$ $\mathrm{C}_{6} \mathrm{H}_{3}(\mathrm{COSY})$ ), 6.68 (br, $\left.1 \mathrm{H}, m-\mathrm{C}_{6} \mathrm{H}_{3}\right), 3.24$ (br, 2H, trans- $\mathrm{CH}_{\mathrm{cod}}$ ), 3.18 (br, 2H, cis- $\mathrm{CH}_{\mathrm{cod}}$ ), 1.97 (s, 6H, Mexyl), 1.96 (br, 6H, $\mathrm{CH}_{2 \mathrm{cod}}(\mathrm{COSY})$ ), 1.82 (s, 6H, Mexyl), 1.57 (m, 2H, $\mathrm{CH}_{2 \mathrm{cod}}$ ), 1.37 (d, ${ }^{1} J_{\mathrm{CP}}=9.8 \mathrm{~Hz}$, $\left.6 \mathrm{H}, \mathrm{PMe}_{2}\right) .{ }^{13} \mathrm{C}\left\{{ }^{1} \mathrm{H}\right\}$ NMR $\left(100 \mathrm{MHz},-15{ }^{\circ} \mathrm{C}, \mathrm{CD}_{2} \mathrm{Cl}_{2}\right) \delta: 134.5$ (overlapped, $\left.p-\mathrm{C}_{6} \mathrm{H}_{3}\right), 130.6\left(\mathrm{~d},{ }^{3} J_{\mathrm{CP}}=\right.$ $\left.15 \mathrm{~Hz}, m-\mathrm{C}_{6} \mathrm{H}_{3}\right), 103.7\left(\mathrm{~d},{ }^{2} J_{\mathrm{CP}}=11 \mathrm{~Hz}\right.$, trans $\left.-\mathrm{CH}_{\mathrm{cod}}\right), 62.3\left(\right.$ cis- $\left.\mathrm{CH}_{\mathrm{cod}}\right), 33.6\left(\mathrm{CH}_{2 \mathrm{cod}}\right), 28.7\left(\mathrm{CH}_{2 \mathrm{cod}}\right)$, $22.7\left(\mathrm{Mexyl}_{\mathrm{Xy}}\right), 21.2\left(\mathrm{Me}_{\mathrm{Xyl}}\right), 12.0\left(\mathrm{~d},{ }^{1} J_{\mathrm{CP}}=37 \mathrm{~Hz}, \mathrm{PMe}_{2}\right) .{ }^{31} \mathrm{P}\left\{{ }^{1} \mathrm{H}\right\} \mathrm{NMR}\left(160 \mathrm{MHz}, 25{ }^{\circ} \mathrm{C}, \mathrm{CD}_{2} \mathrm{Cl}_{2}\right) \delta$ : 16.9 (59\%). 5a: ${ }^{1} \mathrm{H}$ NMR $\left(500 \mathrm{MHz}, 25{ }^{\circ} \mathrm{C}, \mathrm{CD}_{2} \mathrm{Cl}_{2}\right) \delta: 7.76\left(\mathrm{td},{ }^{3} J_{\mathrm{HH}}=7.6 \mathrm{~Hz},{ }^{5} J_{\mathrm{HP}}=2.1 \mathrm{~Hz}, 1 \mathrm{H}, p-\right.$ $\left.\mathrm{C}_{6} \mathrm{H}_{3}\right), 7.63\left(m^{\prime}-\mathrm{C}_{6} \mathrm{H}_{3}(\mathrm{COSY})\right), 7.30\left(\mathrm{t},{ }^{3} J_{\mathrm{HH}}=7.6 \mathrm{~Hz}, 1 \mathrm{H}, p-\mathrm{Xyl}\right), 7.26\left(\mathrm{ddd},{ }^{3} J_{\mathrm{HH}}=7.6 \mathrm{~Hz},{ }^{4} J_{\mathrm{HP}}=3.5\right.$ $\left.\mathrm{Hz},{ }^{4} J_{\mathrm{HH}}=1.2 \mathrm{~Hz}, 1 \mathrm{H}, m-\mathrm{C}_{6} \mathrm{H}_{3}\right), 7.17\left(\mathrm{~d},{ }^{3} J_{\mathrm{HH}}=7.6 \mathrm{~Hz}, 2 \mathrm{H}, m-\mathrm{Xyl}\right), 6.63\left(\mathrm{~d},{ }^{3} J_{\mathrm{HH}}=6.2 \mathrm{~Hz}, 2 \mathrm{H}, m-\right.$ Xyl'), 5.60 (m, 3H, p-Xyl', $\mathrm{CH}_{\mathrm{cod}}$ ), 2.93 (m, 2H, $\mathrm{IrCH}_{\mathrm{cod}}$ ), 2.41 to 2.26 (m, 4H, $\mathrm{CH}_{2 \mathrm{cod}}$ ), 2.17 (s, 6H, Mexyl) 1.98 (m, 2H, CH $2 \operatorname{cod}(\mathrm{COSY})), 1.95\left(\mathrm{~s}, 6 \mathrm{H}, \mathrm{Me}_{\mathrm{Xyl}}\right), 1.76\left(\mathrm{~m}, 2 \mathrm{H}, \mathrm{CH}_{2 \operatorname{cod}}(\mathrm{COSY})\right), 1.28\left(\mathrm{~d},{ }^{1} J_{\mathrm{CP}}=\right.$ $\left.11.3 \mathrm{~Hz}, 6 \mathrm{H}, \mathrm{PMe}_{2}\right) .{ }^{13} \mathrm{C}\left\{{ }^{1} \mathrm{H}\right\} \mathrm{NMR}\left(100 \mathrm{MHz},-15{ }^{\circ} \mathrm{C}, \mathrm{CD}_{2} \mathrm{Cl}_{2}\right) \delta: 140.1\left(\mathrm{~d},{ }^{1} J_{\mathrm{CP}}=59 \mathrm{~Hz}\right.$, ipso- $\left.\mathrm{C}_{6} \mathrm{H}_{3}\right)$, $129.9\left(\mathrm{CH}_{\mathrm{cod}}\right), 127.8$ (overlapped, $\left.m^{\prime}-\mathrm{C}_{6} \mathrm{H}_{3}\right), 108.7$ (o-Xyl'), 107.1 (d, ${ }^{2} J_{\mathrm{CP}}=5 \mathrm{~Hz}$, ipso-Xyl'), 105.0 (d, ${ }^{2} J_{\mathrm{CP}}=3 \mathrm{~Hz}, m$-Xyl'), $86.2\left(\mathrm{~d},{ }^{2} J_{\mathrm{CP}}=10 \mathrm{~Hz}, p\right.$-Xyl'), $52.9\left(\mathrm{IrCH}_{\mathrm{cod}}\right), 36.1\left(\mathrm{CH}_{2 \mathrm{cod}}\right), 32.6\left(\mathrm{CH}_{2 \mathrm{cod}}\right), 21.2$ $\left(\mathrm{Me}_{\mathrm{Xyl}}\right), 19.1\left(\mathrm{Me}_{\mathrm{Xyl}}\right), 13.0\left(\mathrm{~d},{ }^{1} J_{\mathrm{CP}}=40 \mathrm{~Hz}, \mathrm{PMe}_{2}\right) .{ }^{31} \mathrm{P}\left\{{ }^{1} \mathrm{H}\right\} \mathrm{NMR}\left(160 \mathrm{MHz}, 25{ }^{\circ} \mathrm{C}, \mathrm{CD}_{2} \mathrm{Cl}_{2}\right) \delta: 2.0$ (41\%). 4b,5b: Anal. Calcd. for $\mathrm{C}_{72} \mathrm{H}_{67} \mathrm{BF}_{24} \mathrm{IrP}: \mathrm{C}, 53.31$; H, 4.16. Found: C, 53.28; H, 4.50. 4b: ${ }^{1} \mathrm{H}$ NMR (500 MHz, $\left.25^{\circ} \mathrm{C}, \mathrm{CD}_{2} \mathrm{Cl}_{2}\right) \delta: 3.43(\mathrm{~m}, 2 \mathrm{H}$, trans-CHcod), $3.18(\mathrm{~m}, 2 \mathrm{H}$, cis-CHcod), $2.55(\mathrm{~m}, 2 \mathrm{H}$,

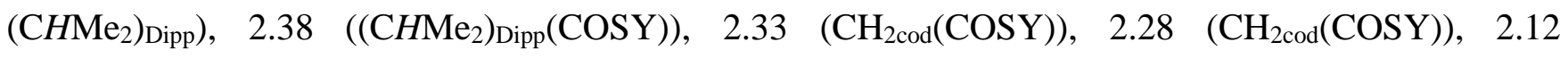
$\left(\mathrm{CH}_{2 \operatorname{cod}}(\mathrm{COSY})\right), 2.05\left(\mathrm{CH}_{2 \operatorname{cod}}(\mathrm{COSY})\right), 1.37$ (d, $\left.{ }^{2} \mathrm{~J}_{\mathrm{HP}}=9.8 \mathrm{~Hz}, 6 \mathrm{H}, \mathrm{PMe}_{2}\right), 1.34\left(\mathrm{Me}_{\text {Dipp }}(\mathrm{COSY})\right), 1.29$ $\left(\mathrm{Me}_{\text {Dipp }}(\mathrm{COSY})\right), 1.11$ (Me Dipp $\left.(\mathrm{COSY})\right), 1.07$ (Me Dipp $\left.(\mathrm{COSY})\right) \cdot{ }^{13} \mathrm{C}\left\{{ }^{1} \mathrm{H}\right\}$ NMR (100 MHz, $25{ }^{\circ} \mathrm{C}$, $\left.\mathrm{CD}_{2} \mathrm{Cl}_{2}\right) \delta: 105.4\left(\mathrm{~d},{ }^{2} J_{\mathrm{CP}}=11 \mathrm{~Hz}\right.$, trans $\left.-\mathrm{CH}_{\mathrm{cod}}\right), 61.0\left(\right.$ cis $\left.-\mathrm{CH}_{\mathrm{cod}}\right), 13.6\left(\mathrm{~d},{ }^{1} J_{\mathrm{CP}}=37 \mathrm{~Hz}, \mathrm{PMe} 2\right) .{ }^{31} \mathrm{P}\left\{{ }^{1} \mathrm{H}\right\}$ NMR (200 MHz, $\left.25{ }^{\circ} \mathrm{C}, \mathrm{CD}_{2} \mathrm{Cl}_{2}\right) \delta: 14.8$ (14\%). 5b: ${ }^{1} \mathrm{H}$ NMR (500 MHz, $\left.25{ }^{\circ} \mathrm{C}, \mathrm{CD}_{2} \mathrm{Cl}_{2}\right) \delta: 7.74$ (overlapped m, $\left.1 \mathrm{H}, m^{\prime}-\mathrm{C}_{6} \mathrm{H}_{3}\right), 7.71\left(\mathrm{td},{ }^{3} J_{\mathrm{HH}}=7.3 \mathrm{~Hz},{ }^{5} J_{\mathrm{HP}}=1.8 \mathrm{~Hz}, 1 \mathrm{H}, p-\mathrm{C}_{6} \mathrm{H}_{3}\right), 7.46\left(\mathrm{t},{ }^{3} J_{\mathrm{HH}}=7.7 \mathrm{~Hz}\right.$, 1H, $p$-Dipp), 7.37 (overlapped m, 1H, $m$ - $\left.\mathrm{C}_{6} \mathrm{H}_{3}\right), 7.28\left(\mathrm{~d},{ }^{3} J_{\mathrm{HH}}=7.7 \mathrm{~Hz}, 2 \mathrm{H}, m\right.$-Dipp), 6.64 (d, ${ }^{3} J_{\mathrm{HH}}=6.3$ $\mathrm{Hz}, 2 \mathrm{H}, m$-Dipp'), 5.77 (t, ${ }^{3} J_{\mathrm{HH}}=6.3 \mathrm{~Hz}, 1 \mathrm{H}, p$-Dipp'), $5.62\left(\mathrm{~m}, 2 \mathrm{H}, \mathrm{CH}_{\mathrm{cod}}\right), 2.96\left(\mathrm{~m}, 2 \mathrm{H}, \mathrm{IrCH} \mathrm{cod}_{\text {) }}\right.$, $2.40\left(\mathrm{~m}, 4 \mathrm{H}, \mathrm{CH}_{2 \mathrm{cod}}\right), 2.25\left(\mathrm{~h},{ }^{3} \mathrm{~J}_{\mathrm{HH}}=6.7 \mathrm{~Hz}, 2 \mathrm{H},(\mathrm{CHMe})_{\text {Dipp }}\right), 2.13\left(\mathrm{~h},{ }^{3} J_{\mathrm{HH}}=6.8 \mathrm{~Hz}, 2 \mathrm{H}\right.$,

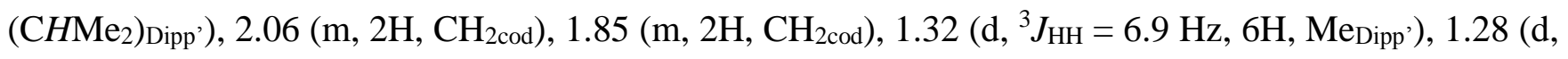
$\left.{ }^{2} J_{\mathrm{HP}}=11.4 \mathrm{~Hz}, 6 \mathrm{H}, \mathrm{PMe}_{2}\right), 1.24\left(\mathrm{~m}, 12 \mathrm{H}, \mathrm{Me}_{\text {Dipp }}, \mathrm{Me}_{\mathrm{Dipp}}\right), 1.00\left(\mathrm{~d},{ }^{3} J_{\mathrm{HH}}=6.6 \mathrm{~Hz}, 6 \mathrm{H}, \mathrm{Me}_{\mathrm{Dipp}}\right) .{ }^{13} \mathrm{C}\left\{{ }^{1} \mathrm{H}\right\}$ NMR (100 MHz, $\left.25^{\circ} \mathrm{C}, \mathrm{CD}_{2} \mathrm{Cl}_{2}\right) \delta: 147.2$ (o-Dipp), $146.3\left(o-\mathrm{C}_{6} \mathrm{H}_{3}\right), 142.3\left(\mathrm{~d},{ }^{1} J_{\mathrm{CP}}=59 \mathrm{~Hz}\right.$, ipso-C $\left.\mathrm{C}_{6} \mathrm{H}_{3}\right)$, $141.2\left(\mathrm{~d},{ }^{2} J_{\mathrm{CP}}=18 \mathrm{~Hz}, o-\mathrm{C}_{6} \mathrm{H}_{3}\right), 135.5$ (ipso-Dipp), $134.7\left(\mathrm{~d},{ }^{3} J_{\mathrm{CP}}=7 \mathrm{~Hz}, m-\mathrm{C}_{6} \mathrm{H}_{3}\right), 132.0\left(p-\mathrm{C}_{6} \mathrm{H}_{3}\right)$, 130.7 (p-Dipp), 130.4 ( $\left.\mathrm{CH}_{\text {cod }}\right), 128.8$ (d, $\left.{ }^{3} J_{\mathrm{CP}}=7 \mathrm{~Hz}, m^{\prime}-\mathrm{C}_{6} \mathrm{H}_{3}\right), 123.7$ (m-Dipp), 120.1 (o-Dipp'), 106.9 (d, ${ }^{2} J_{\mathrm{CP}}=5 \mathrm{~Hz}$, ipso-Dipp'), $101.7\left(\mathrm{~d},{ }^{2} J_{\mathrm{CP}}=4 \mathrm{~Hz}, m\right.$-Dipp'), 88.3 (d, ${ }^{2} J_{\mathrm{CP}}=11 \mathrm{~Hz}, p$-Dipp'), 53.5 $\left(\mathrm{IrCH}_{\text {cod }}\right), 36.7\left(\mathrm{CH}_{2 \mathrm{cod}}\right), 32.8\left(\mathrm{CH}_{2 \mathrm{cod}}\right), 31.7\left(\left(\mathrm{CHMe}_{2}\right)_{\text {Dipp }}\right), 29.7\left(\left(\mathrm{CHMe}_{2}\right)_{\text {Dipp }}\right), 26.3\left(\mathrm{Me}_{\text {Dipp }}\right), 24.7$

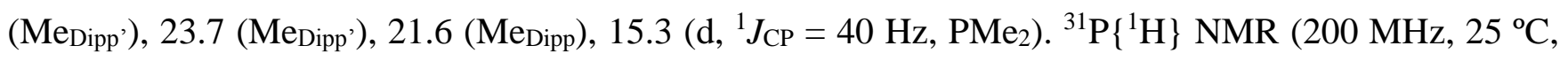
$\left.\mathrm{CD}_{2} \mathrm{Cl}_{2}\right) \delta: 1.9(86 \%)$. 
[Ir(cod)(py)PMe2Ar $\left.{ }^{\text {Xyl2 }}\right][$ BArF] (6a): Pyridine $(0.020 \mathrm{mmol})$ was added to a dichloromethane solution of complexes $4 \mathbf{a}$ and $\mathbf{5 a}(0.018 \mathrm{mmol})$, which immediately turned from red to light orange. The solution was stirred for $5 \mathrm{~min}$ at room temperature and the solvent was removed under reduced pressure. Excess pyridine was evaporated together with pentane $(2 \times 5 \mathrm{~mL})$. The finely divided orange solid was washed with pentane $(5 \mathrm{~mL})$ and dried under reduced pressure, affording complex $6 \mathrm{a}$ in $82 \%$ yield. Anal. Calcd. for $\mathrm{C}_{69} \mathrm{H}_{56} \mathrm{BF}_{24} \mathrm{IrNP}: \mathrm{C}, 52.15 ; \mathrm{H}, 3.55 ; \mathrm{N}, 0.88$. Found: C, 52.46; H, 3.43; N, 0.69. ${ }^{1} \mathrm{H}$ NMR (400 MHz, $\left.\mathrm{CD}_{2} \mathrm{Cl}_{2}, 25^{\circ} \mathrm{C}\right) \delta: 8.06(\mathrm{~m}, 2 \mathrm{H}, 2,6-\mathrm{py}), 7.72(\mathrm{~m}, 9 \mathrm{H}, o-\mathrm{Ar}, 4-\mathrm{py}), 7.57\left(\mathrm{td},{ }^{3} J_{\mathrm{HH}}=7.7 \mathrm{~Hz},{ }^{5} J_{\mathrm{HP}}=1.7 \mathrm{~Hz}\right.$, $\left.1 \mathrm{H}, p-\mathrm{C}_{6} \mathrm{H}_{3}\right), 7.56$ (s, 4H, p-Ar), 7.31 (m, 4H, 3,5-py, p-Xyl), 7.18 (d, $\left.{ }^{3} J_{\mathrm{HH}}=7.5 \mathrm{~Hz}, 4 \mathrm{H}, m-X y \mathrm{l}\right), 7.09$ $\left(\mathrm{dd},{ }^{3} J_{\mathrm{HH}}=7.6 \mathrm{~Hz},{ }^{4} J_{\mathrm{HP}}=3.1 \mathrm{~Hz}, 2 \mathrm{H}, m-\mathrm{C}_{6} \mathrm{H}_{3}\right), 3.98\left(\mathrm{~m}, 2 \mathrm{H}, \mathrm{CH}_{\mathrm{cod}}\right), 3.49$ (br, $\left.2 \mathrm{H}, \mathrm{CH}_{\mathrm{cod}}\right), 2.28$ to 2.18 (m, 4H, $\mathrm{CH}_{2 \mathrm{cod}}$ ), 2.15 (s, 12H, Me $\mathrm{Xyl}$ ), 1.87 to 1.72 (m, $4 \mathrm{H}, \mathrm{CH}_{2 \mathrm{cod}}$ ), 0.82 (d, ${ }^{2} J_{\mathrm{HP}}=8.3 \mathrm{~Hz}, 6 \mathrm{H}, \mathrm{PMe}_{2}$ ). ${ }^{13} \mathrm{C}\left\{{ }^{1} \mathrm{H}\right\}$ NMR $\left(100 \mathrm{MHz}, \mathrm{CD}_{2} \mathrm{Cl}_{2}, 25{ }^{\circ} \mathrm{C}\right) \delta: 162.2$ (q, ${ }^{1} J_{\mathrm{CB}}=50 \mathrm{~Hz}$, ipso-Ar), 150.6 (2,6-py), 145.9 (d, $\left.{ }^{2} J_{\mathrm{CP}}=10 \mathrm{~Hz}, o-\mathrm{C}_{6} \mathrm{H}_{3}\right), 141.2\left(\mathrm{~d},{ }^{3} J_{\mathrm{CP}}=3 \mathrm{~Hz}\right.$, ipso-Xyl), 139.0 (4-py), 137.4 (o-Xyl), 135.2 (o-Ar), $132.3\left(\mathrm{~d},{ }^{3} J_{\mathrm{CP}}=8 \mathrm{~Hz}, m-\mathrm{C}_{6} \mathrm{H}_{3}\right), 131.8\left(\mathrm{~d},{ }^{4} J_{\mathrm{CP}}=2 \mathrm{~Hz}, p-\mathrm{C}_{6} \mathrm{H}_{3}\right), 129.3\left(\mathrm{q},{ }^{2} J_{\mathrm{CF}}=31 \mathrm{~Hz}, m-\mathrm{Ar}\right), 129.0(p-$ $\mathrm{Xyl}), 128.4$ (m-Xyl), 127.4 (3,5-py), $126.8\left(\mathrm{~d},{ }^{1} J_{\mathrm{CP}}=41 \mathrm{~Hz}\right.$, ipso- $\left.\mathrm{C}_{6} \mathrm{H}_{3}\right), 125.0$ (q, $\left.{ }^{1} J_{\mathrm{CF}}=272 \mathrm{~Hz}, \mathrm{CF}_{3}\right)$, 117.9 (m, p-Ar), 89.7 (d, ${ }^{2} J_{\mathrm{CP}}=13 \mathrm{~Hz}, \mathrm{CH}_{\mathrm{cod}}$ ), 66.4 (br, $\mathrm{CH}_{\mathrm{cod}}$ ), 32.7 (br, $\mathrm{CH}_{2 \mathrm{cod}}$ ), 29.4 (br, $\mathrm{CH}_{2 \mathrm{cod}}$ ), $22.4\left(\mathrm{Me}_{\mathrm{Xyl}}\right), 14.3\left(\mathrm{~d},{ }^{1} J_{\mathrm{CP}}=34 \mathrm{~Hz}, \mathrm{PMe}_{2}\right) .{ }^{31} \mathrm{P}\left\{{ }^{1} \mathrm{H}\right\} \mathrm{NMR}\left(160 \mathrm{MHz}, \mathrm{CD}_{2} \mathrm{Cl}_{2}, 25{ }^{\circ} \mathrm{C}\right) \delta:-12.1$.

[Rh( $\left.\left.\mathbf{C}_{2} \mathrm{H}_{4}\right) \mathbf{P M e} 2 \mathrm{Ar} \mathbf{r}^{\prime}\right][\mathbf{B A r F}]$ (7): A solid mixture of [ $\left.\mathrm{RhCl}\left(\mathrm{C}_{2} \mathrm{H}_{2}\right)_{2}\right]_{2}(0.20 \mathrm{mmol}), \mathrm{PMe}_{2} \mathrm{Ar}{ }^{\prime}(0.40$ mmol) and $\operatorname{NaBAr}_{F}(0.40 \mathrm{mmol})$, placed in a Schlenk flask, was dissolved in $\mathrm{CH}_{2} \mathrm{Cl}_{2}(6 \mathrm{~mL})$. The solution was stirred for 1 hour at room temperature, filtered and the solvent evaporated under reduced pressure to obtain complex 7 as a yellow powder in $c a$. 90\% yield. Single crystals were grown from a saturated hexane-dichloromethane solution. 7a: Anal. Calc. for $\mathrm{C}_{58} \mathrm{H}_{43} \mathrm{BF}_{24} \mathrm{PRh}$ : C, 52.0; H, 3.23. Found: C, 52.0; H, 3.52. ${ }^{1} \mathrm{H}$ NMR $\left(500 \mathrm{MHz}, 25{ }^{\circ} \mathrm{C}, \mathrm{CD}_{2} \mathrm{Cl}_{2}\right) \delta: 7.84\left(\mathrm{td},{ }^{3} J_{\mathrm{HH}}=7.6 \mathrm{~Hz},{ }^{5} J_{\mathrm{HP}}=2.4 \mathrm{~Hz}\right.$, $\left.1 \mathrm{H}, p-\mathrm{C}_{6} \mathrm{H}_{3}\right), 7.65\left(\mathrm{ddd},{ }^{3} J_{\mathrm{HH}}=7.7 \mathrm{~Hz},{ }^{4} J_{\mathrm{HP}}=2.3 \mathrm{~Hz},{ }^{4} J_{\mathrm{HH}}=1.3 \mathrm{~Hz}, 1 \mathrm{H}, m^{\prime}-\mathrm{C}_{6} \mathrm{H}_{3}\right), 7.31(\mathrm{~m}, 2 \mathrm{H}, p-\mathrm{Xyl}$, $\left.m-\mathrm{C}_{6} \mathrm{H}_{3}\right), 7.19\left(\mathrm{~d},{ }^{3} J_{\mathrm{HH}}=7.6 \mathrm{~Hz}, 2 \mathrm{H}, m-\mathrm{Xyl}\right), 6.96\left(\mathrm{~d},{ }^{3} J_{\mathrm{HH}}=6.6 \mathrm{~Hz}, 2 \mathrm{H}, m-\mathrm{Xyl}{ }^{\prime}\right), 5.54\left(\mathrm{td},{ }^{3} J_{\mathrm{HH}}=6.6\right.$ $\mathrm{Hz},{ }^{3} J_{\mathrm{HP}}=2.3 \mathrm{~Hz}, 1 \mathrm{H}, p$-Xyl'), 2.92 (br s, 4H, C2 $\mathrm{H}_{4}$ ), 2.18 (s, 6H, Mexyl'), 1.99 (s, 6H, Mexyl), 1.18 (dd, $\left.{ }^{2} J_{\mathrm{HP}}=11.5 \mathrm{~Hz},{ }^{3} J_{\mathrm{HRh}}=1.4 \mathrm{~Hz}, 6 \mathrm{H}, \mathrm{PMe}_{2}\right) .{ }^{13} \mathrm{C}\left\{{ }^{1} \mathrm{H}\right\} \mathrm{NMR}\left(125 \mathrm{MHz}, 25{ }^{\circ} \mathrm{C}, \mathrm{CD}_{2} \mathrm{Cl}_{2}\right) \delta: 147.5\left(o-\mathrm{C}_{6} \mathrm{H}_{3}\right)$, $142.8\left(\mathrm{~d},{ }^{2} J_{\mathrm{CP}}=20 \mathrm{~Hz}, o-\mathrm{C}_{6} \mathrm{H}_{3}\right), 138.8\left(\mathrm{~d},{ }^{1} J_{\mathrm{CP}}=52 \mathrm{~Hz}\right.$, ipso- $\left.\mathrm{C}_{6} \mathrm{H}_{3}\right), 137.8$ (ipso-Xyl), 136.6 (o-Xyl), $133.9\left(\mathrm{~d},{ }^{4} J_{\mathrm{CP}}=2 \mathrm{~Hz}, p-\mathrm{C}_{6} \mathrm{H}_{3}\right), 132.8\left(\mathrm{~d},{ }^{3} J_{\mathrm{CP}}=6 \mathrm{~Hz}, m-\mathrm{C}_{6} \mathrm{H}_{3}\right), 129.0(p-\mathrm{Xyl}), 128.1(m-\mathrm{Xyl}), 128.0$ ( $m^{\prime}-\mathrm{C}_{6} \mathrm{H}_{3}$ ), 117.9 (o-Xyl'), 116.5 (ipso-Xyl'), 109.1 (m-Xyl'), 94.7 (d, ${ }^{2} J_{\mathrm{CP}}=12 \mathrm{~Hz}, p$-Xyl'), 46.5 (d, $\left.{ }^{1} J_{\mathrm{CRh}}=13 \mathrm{~Hz}, \mathrm{C}_{2} \mathrm{H}_{4}\right), 21.3\left(\mathrm{Me}_{\mathrm{Xyl}}\right), 19.6\left(\mathrm{Me}_{\mathrm{Xyl}}\right), 13.9\left(\mathrm{~d},{ }^{1} J_{\mathrm{CP}}=33 \mathrm{~Hz}, \mathrm{PMe}_{2}\right) .{ }^{31} \mathrm{P}\left\{{ }^{1} \mathrm{H}\right\} \mathrm{NMR}(200$ $\left.\mathrm{MHz}, 25^{\circ} \mathrm{C}, \mathrm{CD}_{2} \mathrm{Cl}_{2}\right) \delta: 48.1\left(\mathrm{~d},{ }^{1} J_{\mathrm{PRh}}=185 \mathrm{~Hz}\right)$. 7b: Anal. Calc. for $\mathrm{C}_{66} \mathrm{H}_{59} \mathrm{BF}_{24} \mathrm{PRh}$ : C, 54.56; H, 4.09. Found: C, 54.65; H, 3.98. ${ }^{1} \mathrm{H} \mathrm{NMR}\left(400 \mathrm{MHz}, 25{ }^{\circ} \mathrm{C}, \mathrm{CD}_{2} \mathrm{Cl}_{2}\right) \delta: 7.76\left(\mathrm{td},{ }^{3} \mathrm{~J}_{\mathrm{HH}}=7.6 \mathrm{~Hz},{ }^{5} J_{\mathrm{HP}}=2.3 \mathrm{~Hz}\right.$, $\left.1 \mathrm{H}, p-\mathrm{C}_{6} \mathrm{H}_{3}\right), 7.73(\mathrm{~s}, 8 \mathrm{H}, o-\mathrm{Ar}), 7.70\left(\mathrm{ddd},{ }^{3} J_{\mathrm{HH}}=7.7 \mathrm{~Hz},{ }^{4} J_{\mathrm{HP}}=2.2 \mathrm{~Hz},{ }^{4} J_{\mathrm{HH}}=1.4 \mathrm{~Hz}, 1 \mathrm{H}, m^{\prime}-\mathrm{C}_{6} \mathrm{H}_{3}\right)$, $7.57\left(\mathrm{~s}, 4 \mathrm{H}, p\right.$-Ar), $7.45\left(\mathrm{t},{ }^{3} J_{\mathrm{HH}}=7.8 \mathrm{~Hz}, 1 \mathrm{H}, p\right.$-Dipp), $7.41\left(\mathrm{ddd},{ }^{3} J_{\mathrm{HH}}=7.5 \mathrm{~Hz},{ }^{4} J_{\mathrm{HP}}=3.4 \mathrm{~Hz},{ }^{4} J_{\mathrm{HH}}=\right.$ 
$\left.1.4 \mathrm{~Hz}, 1 \mathrm{H}, m-\mathrm{C}_{6} \mathrm{H}_{3}\right), 7.27\left(\mathrm{~d},{ }^{3} J_{\mathrm{HH}}=7.8 \mathrm{~Hz}, 2 \mathrm{H}, m\right.$-Dipp), $6.96\left(\mathrm{~d},{ }^{3} J_{\mathrm{HH}}=6.8 \mathrm{~Hz}, 2 \mathrm{H}, m\right.$-Dipp'), 5.70 $\left(\mathrm{td},{ }^{3} J_{\mathrm{HH}}=6.8 \mathrm{~Hz},{ }^{3} J_{\mathrm{HP}}=2.2 \mathrm{~Hz}, 1 \mathrm{H}, p\right.$-Dipp'), 2.88 (br s, 4H, $\left.\mathrm{C}_{2} \mathrm{H}_{4}\right), 2.24\left(\mathrm{~m}, 4 \mathrm{H},\left(\mathrm{CHMe}_{2}\right)_{\text {Dipp }}\right.$, $\left.\left(\mathrm{CHMe}_{2}\right)_{\text {Dipp }}\right), 1.32\left(\mathrm{~d},{ }^{3} J_{\mathrm{HH}}=6.9 \mathrm{~Hz}, 6 \mathrm{H}, \mathrm{Me}_{\text {Dipp }}\right), 1.25\left(\mathrm{~d},{ }^{3} J_{\mathrm{HH}}=6.8 \mathrm{~Hz}, 6 \mathrm{H}, \mathrm{Me}_{\mathrm{Dipp}}\right), 1.23\left(\mathrm{~d},{ }^{3} J_{\mathrm{HH}}=\right.$ $\left.6.9 \mathrm{~Hz}, 6 \mathrm{H}, \mathrm{Me}_{\mathrm{Dipp}}\right), 1.12\left(\mathrm{dd},{ }^{2} J_{\mathrm{HP}}=11.5 \mathrm{~Hz},{ }^{3} J_{\mathrm{HRh}}=1.3 \mathrm{~Hz}, 6 \mathrm{H}, \mathrm{PMe}\right), 1.00\left(\mathrm{~d},{ }^{3} J_{\mathrm{HH}}=6.6 \mathrm{~Hz}, 6 \mathrm{H}\right.$, Me Dipp). ${ }^{13} \mathrm{C}\left\{{ }^{1} \mathrm{H}\right\}$ NMR $\left(100 \mathrm{MHz}, 25^{\circ} \mathrm{C}, \mathrm{CD}_{2} \mathrm{Cl}_{2}\right) \delta$ : 162.2 (q, ${ }^{1} J_{\mathrm{CB}}=50 \mathrm{~Hz}$, ipso-Ar), 147.2 (o-Dipp), $145.7\left(o-\mathrm{C}_{6} \mathrm{H}_{3}\right), 141.8\left(\mathrm{~d},{ }^{2} J_{\mathrm{CP}}=21 \mathrm{~Hz}, o-\mathrm{C}_{6} \mathrm{H}_{3}\right), 140.4\left(\mathrm{~d},{ }^{1} J_{\mathrm{CP}}=50 \mathrm{~Hz}\right.$, ipso- $\left.\mathrm{C}_{6} \mathrm{H}_{3}\right), 135.2(o-\mathrm{Ar}$, ipsoDipp), $134.3\left(\mathrm{~d},{ }^{3} J_{\mathrm{CP}}=7 \mathrm{~Hz}, m-\mathrm{C}_{6} \mathrm{H}_{3}\right), 132.1\left(p-\mathrm{C}_{6} \mathrm{H}_{3}\right), 130.6$ (p-Dipp), 129.3 (q, $\left.{ }^{2} J_{\mathrm{CF}}=31 \mathrm{~Hz}, m-\mathrm{Ar}\right)$, 128.9 (o-Dipp'), 128.6 (d, $\left.{ }^{3} J_{\mathrm{CP}}=15 \mathrm{~Hz}, m^{\prime}-\mathrm{C}_{6} \mathrm{H}_{3}\right), 125.0\left(\mathrm{q},{ }^{1} J_{\mathrm{CF}}=272 \mathrm{~Hz}, \mathrm{CF}_{3}\right), 123.6$ ( $m$-Dipp), 117.9 (m, p-Ar), 115.5 (t, ${ }^{2} J_{\mathrm{CP}}={ }^{1} J_{\mathrm{CRh}}=4 \mathrm{~Hz}$, ipso-Dipp'), 105.0 ( $m$-Dipp'), 96.0 (d, ${ }^{2} J_{\mathrm{CP}}=11 \mathrm{~Hz}, p$-Dipp'), $\left.\left.46.0\left(\mathrm{~d},{ }^{1} J_{\mathrm{CRh}}=13 \mathrm{~Hz}, \mathrm{C}_{2} \mathrm{H}_{4}\right), 31.6\left(\mathrm{CHMe}_{2}\right)_{\text {Dipp }}\right), 30.1\left(\mathrm{CHMe}_{2}\right)_{\text {Dipp' }}\right), 26.4\left(\mathrm{Me}_{\text {Dipp }}\right), 25.1\left(\mathrm{Me}_{\text {Dipp' }}\right)$,

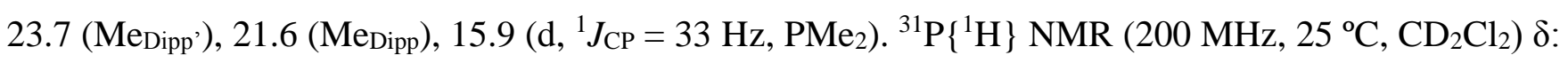
$48.4\left(\mathrm{~d},{ }^{1} J_{\mathrm{PRh}}=183 \mathrm{~Hz}\right)$.

[ $\operatorname{Ir}\left(\mathbf{C}_{2} \mathbf{H}_{4}\right) \mathbf{P M e}$ Ar'][BArF] (8): Ethylene was bubbled through a deoxygenated pentane solution of $\left[\mathrm{IrCl}(\mathrm{coe})_{2}\right]_{2}\left(0.11 \mathrm{mmol}, 15 \mathrm{~mL},-20^{\circ} \mathrm{C}\right)$ in an ampoule, until the yellow coloration fades. A red precipitate formed upon addition of the phosphine $(0.22 \mathrm{mmol})$ dissolved in pentane $(8 \mathrm{~mL}) . \mathrm{NaBAr}_{\mathrm{F}}$ $(0.22 \mathrm{mmol})$ was suspended in $\mathrm{CH}_{2} \mathrm{Cl}_{2}(8 \mathrm{~mL})$ and added to the reaction mixture, which gradually turned pale yellow. The solution was allowed to reach room temperature and the solvent was removed under reduced pressure. The complex was extracted with $\mathrm{CH}_{2} \mathrm{Cl}_{2}(8 \mathrm{~mL})$, the solvent evaporated under reduced pressure and the solid washed with pentane $(10 \mathrm{~mL})$, yielding complex $\mathbf{8}$ as a pure, pale solid in ca. 80\% yield. 8a: Anal. Calc. for $\mathrm{C}_{58} \mathrm{H}_{43} \mathrm{BF}_{24} \mathrm{IrP}$ : C, 48.72; H, 3.03. Found: C, 48.92; H, 3.09. ${ }^{1} \mathrm{H}$ NMR $\left(400 \mathrm{MHz}, \mathrm{CD}_{2} \mathrm{Cl}_{2}, 25^{\circ} \mathrm{C}\right) \delta: 7.74\left(\mathrm{~s}, 8 \mathrm{H}, o\right.$-Ar), 7.73 (overlapped m, 1H, $\left.p-\mathrm{C}_{6} \mathrm{H}_{3}\right), 7.64\left(\mathrm{ddd},{ }^{3} J_{\mathrm{HH}}=7.6\right.$ $\left.\mathrm{Hz},{ }^{4} J_{\mathrm{HP}}=2.1 \mathrm{~Hz},{ }^{4} J_{\mathrm{HH}}=1.1 \mathrm{~Hz}, 1 \mathrm{H}, m^{\prime}-\mathrm{C}_{6} \mathrm{H}_{3}\right), 7.56(\mathrm{~s}, 4 \mathrm{H}, p-\mathrm{Ar}), 7.25\left(\mathrm{t},{ }^{3} J_{\mathrm{HH}}=7.7 \mathrm{~Hz}, 1 \mathrm{H}, p-\mathrm{Xyl}\right)$, $7.21\left(\mathrm{ddd},{ }^{3} J_{\mathrm{HH}}=7.5 \mathrm{~Hz},{ }^{4} J_{\mathrm{HP}}=3.4 \mathrm{~Hz},{ }^{4} J_{\mathrm{HH}}=1.1 \mathrm{~Hz}, 1 \mathrm{H}, m-\mathrm{C}_{6} \mathrm{H}_{3}\right), 7.13\left(\mathrm{~d},{ }^{3} J_{\mathrm{HH}}=7.6 \mathrm{~Hz}, 2 \mathrm{H}, m-\mathrm{Xyl}\right)$, $\left.\left.6.78\left(\mathrm{~d},{ }^{3} J_{\mathrm{HH}}=6.2 \mathrm{~Hz}, 2 \mathrm{H}, m-\mathrm{Xyl}\right)^{\prime}\right), 5.30\left(\mathrm{td},{ }^{3} J_{\mathrm{HH}}=6.2 \mathrm{~Hz},{ }^{3} J_{\mathrm{HP}}=1.7 \mathrm{~Hz}, 1 \mathrm{H}, p-\mathrm{Xyl}\right)^{\prime}\right), 2.93(\mathrm{~m}, 2 \mathrm{H}$, $\mathrm{C} H \mathrm{H}=\mathrm{CHH}), 2.18(\mathrm{~s}, 6 \mathrm{H}, \mathrm{Mexyl}), 1.93\left(\mathrm{~s}, 6 \mathrm{H}, \mathrm{Me}_{\mathrm{xyl}}\right), 1.74(\mathrm{~m}, 2 \mathrm{H}, \mathrm{CH} H=\mathrm{CH} H), 1.24\left(\mathrm{~d},{ }^{2} J_{\mathrm{HP}}=11.4\right.$ $\left.\mathrm{Hz}, 6 \mathrm{H}, \mathrm{PMe}_{2}\right) .{ }^{13} \mathrm{C}\left\{{ }^{1} \mathrm{H}\right\} \mathrm{NMR}\left(100 \mathrm{MHz}, \mathrm{CD}_{2} \mathrm{Cl}_{2}, 25{ }^{\circ} \mathrm{C}\right) \delta: 162.3$ (q, ${ }^{1} J_{\mathrm{CB}}=50 \mathrm{~Hz}$, ipso-Ar), 148.4 (o$\left.\mathrm{C}_{6} \mathrm{H}_{3}\right), 142.2\left(\mathrm{~d},{ }^{2} J_{\mathrm{CP}}=18 \mathrm{~Hz}, o-\mathrm{C}_{6} \mathrm{H}_{3}\right), 141.3\left(\mathrm{~d},{ }^{1} J_{\mathrm{CP}}=59 \mathrm{~Hz}\right.$, ipso- $\left.\mathrm{C}_{6} \mathrm{H}_{3}\right), 137.9\left(\mathrm{~d},{ }^{3} J_{\mathrm{CP}}=2 \mathrm{~Hz}\right.$, ipso$\mathrm{Xyl}$ ), 136.7 (o-Xyl), 135.3 (o-Ar), $134.0\left(p-\mathrm{C}_{6} \mathrm{H}_{3}\right), 133.3$ (d, $\left.{ }^{3} J_{\mathrm{CP}}=7 \mathrm{~Hz}, m-\mathrm{C}_{6} \mathrm{H}_{3}\right), 129.7$ (p-Xyl), 129.4 $\left(\mathrm{q},{ }^{2} J_{\mathrm{CF}}=31 \mathrm{~Hz}, m-\mathrm{Ar}\right), 128.3\left(\mathrm{~m}, m^{\prime}-\mathrm{C}_{6} \mathrm{H}_{3}, m-\mathrm{Xyl}\right), 125.1\left(\mathrm{q},{ }^{1} J_{\mathrm{CF}}=272 \mathrm{~Hz}, \mathrm{CF}_{3}\right), 118.0(\mathrm{~m}, p-\mathrm{Ar})$, $110.6(o-X y l '), 109.5$ (d, ${ }^{2} J_{\mathrm{CP}}=5 \mathrm{~Hz}$, ipso-Xyl'), $102.6\left(\mathrm{~d},{ }^{2} J_{\mathrm{CP}}=4 \mathrm{~Hz}, m-X \mathrm{yl}{ }^{\prime}\right), 84.7\left(\mathrm{~d},{ }^{2} J_{\mathrm{CP}}=11 \mathrm{~Hz}\right.$, p-Xyl'), $24.5\left(\mathrm{C}_{2} \mathrm{H}_{4}\right), 21.4\left(\mathrm{Me}_{\mathrm{Xyl}}\right), 19.1\left(\mathrm{Me}_{\mathrm{Xyl}}\right), 13.4\left(\mathrm{~d},{ }^{1} J_{\mathrm{CP}}=40 \mathrm{~Hz}, \mathrm{PMe}_{2}\right) .{ }^{31} \mathrm{P}\left\{{ }^{1} \mathrm{H}\right\} \mathrm{NMR}(160$ $\left.\mathrm{MHz}, \mathrm{CD}_{2} \mathrm{Cl}_{2}, 25^{\circ} \mathrm{C}\right) \delta$ : 2.1. 8b: Anal. Calc. for $\mathrm{C}_{66} \mathrm{H}_{60} \mathrm{BF}_{24} \mathrm{IrP}: \mathrm{C}, 51.37$; H, 3.92. Found: C, 51.40; H, 4.07. ${ }^{1} \mathrm{H}$ NMR $\left(500 \mathrm{MHz}, \mathrm{CD}_{2} \mathrm{Cl}_{2}, 25{ }^{\circ} \mathrm{C}\right) \delta: 7.77\left(\mathrm{ddd},{ }^{3} J_{\mathrm{HH}}=7.6 \mathrm{~Hz},{ }^{4} J_{\mathrm{HP}}=2.2 \mathrm{~Hz},{ }^{4} J_{\mathrm{HH}}=1.4 \mathrm{~Hz}, 1 \mathrm{H}\right.$, $\left.m^{\prime}-\mathrm{C}_{6} \mathrm{H}_{3}\right), 7.73\left(\mathrm{td}\right.$ overlapped, $\left.{ }^{3} J_{\mathrm{HH}}=7.5 \mathrm{~Hz},{ }^{5} J_{\mathrm{HP}}=2.2 \mathrm{~Hz}, 1 \mathrm{H}, p-\mathrm{C}_{6} \mathrm{H}_{3}\right), 7.72(\mathrm{~s}, 8 \mathrm{H}, o-\mathrm{Ar}), 7.56(\mathrm{~s}$, 
$4 \mathrm{H}, p$-Ar), $7.46\left(\mathrm{t},{ }^{3} J_{\mathrm{HH}}=7.8 \mathrm{~Hz}, 1 \mathrm{H}, p\right.$-Dipp), $7.38\left(\mathrm{ddd},{ }^{3} J_{\mathrm{HH}}=7.3 \mathrm{~Hz},{ }^{4} J_{\mathrm{HP}}=3.6 \mathrm{~Hz},{ }^{4} J_{\mathrm{HH}}=1.3 \mathrm{~Hz}\right.$, $\left.1 \mathrm{H}, m-\mathrm{C}_{6} \mathrm{H}_{3}\right), 7.27\left(\mathrm{~d},{ }^{3} J_{\mathrm{HH}}=7.8 \mathrm{~Hz}, 2 \mathrm{H}, m\right.$-Dipp$), 6.88\left(\mathrm{dd},{ }^{3} J_{\mathrm{HH}}=6.4 \mathrm{~Hz},{ }^{3} J_{\mathrm{HP}}=0.7 \mathrm{~Hz}, 2 \mathrm{H}, m\right.$-Dipp'), $5.57\left(\mathrm{td},{ }^{3} J_{\mathrm{HH}}=6.4 \mathrm{~Hz},{ }^{3} J_{\mathrm{HP}}=1.7 \mathrm{~Hz}, 1 \mathrm{H}, p\right.$-Dipp'), $2.97(\mathrm{~m}, 2 \mathrm{H}, \mathrm{CHH}=\mathrm{CHH}), 2.22\left(\mathrm{~h},{ }^{3} J_{\mathrm{HH}}=6.7 \mathrm{~Hz}\right.$, $\left.2 \mathrm{H},(\mathrm{CHMe})_{\text {Dipp }}\right), 2.16\left(\mathrm{~h},{ }^{3} J_{\mathrm{HH}}=6.9 \mathrm{~Hz}, 2 \mathrm{H},(\mathrm{CHMe})_{\text {Dipp }}\right), 1.79(\mathrm{~m}, 2 \mathrm{H}, \mathrm{CH} H=\mathrm{CH} H), 1.30\left(\mathrm{~d},{ }^{3} J_{\mathrm{HH}}=\right.$ $6.9 \mathrm{~Hz}, 6 \mathrm{H}, \mathrm{Me}_{\mathrm{Dipp}}$ ), 1.28 (d, ${ }^{3} J_{\mathrm{HH}}=6.8 \mathrm{~Hz}, 6 \mathrm{H}, \mathrm{Me}_{\mathrm{Dipp}}$ ), $1.24\left(\mathrm{~d},{ }^{2} J_{\mathrm{HP}}=11.4 \mathrm{~Hz}, 6 \mathrm{H}, \mathrm{PMe}_{2}\right), 1.23(\mathrm{~d}$, $\left.{ }^{3} J_{\mathrm{HH}}=6.7 \mathrm{~Hz}, 6 \mathrm{H}, \mathrm{Me}_{\text {Dipp }}\right), 1.00\left(\mathrm{~d},{ }^{3} J_{\mathrm{HH}}=6.7 \mathrm{~Hz}, 6 \mathrm{H}, \mathrm{Me}_{\text {Dipp }}\right) \cdot{ }^{13} \mathrm{C}\left\{{ }^{1} \mathrm{H}\right\} \mathrm{NMR}\left(100 \mathrm{MHz}, \mathrm{CD}_{2} \mathrm{Cl}_{2}, 25\right.$ $\left.{ }^{\circ} \mathrm{C}\right) \delta: 162.3\left(\mathrm{q},{ }^{1} J_{\mathrm{CB}}=50 \mathrm{~Hz}\right.$, ipso-Ar), 147.2 (o-Dipp), $146.5\left(o-\mathrm{C}_{6} \mathrm{H}_{3}\right), 142.7\left(\mathrm{~d},{ }^{1} J_{\mathrm{CP}}=59 \mathrm{~Hz}\right.$, ipso$\left.\mathrm{C}_{6} \mathrm{H}_{3}\right), 141.2\left(\mathrm{~d},{ }^{2} J_{\mathrm{CP}}=18 \mathrm{~Hz}, o-\mathrm{C}_{6} \mathrm{H}_{3}\right), 135.3$ (o-Ar, ipso-Dipp (overlapped)), 134.7 (d, ${ }^{3} J_{\mathrm{CP}}=7 \mathrm{~Hz}, m^{-}$ $\left.\mathrm{C}_{6} \mathrm{H}_{3}\right), 132.1\left(p-\mathrm{C}_{6} \mathrm{H}_{3}\right), 130.7$ (p-Dipp), 129.3 (q, ${ }^{2} J_{\mathrm{CF}}=31 \mathrm{~Hz}, m$-Ar), 128.8 (d, ${ }^{3} J_{\mathrm{CP}}=13 \mathrm{~Hz}, m$ '- $\left.\mathrm{C}_{6} \mathrm{H}_{3}\right)$, $125.1\left(\mathrm{q},{ }^{1} J_{\mathrm{CF}}=272 \mathrm{~Hz}, \mathrm{CF}_{3}\right), 123.6$ (m-Dipp), 121.5 (o-Dipp'), 117.9 (m, $p$-Ar), $108.7\left(\mathrm{~d},{ }^{2} J_{\mathrm{CP}}=5 \mathrm{~Hz}\right.$, ipso-Dipp'), 98.3 (d, ${ }^{2} J_{\mathrm{CP}}=4 \mathrm{~Hz}, m$-Dipp'), 86.0 (d, ${ }^{2} J_{\mathrm{CP}}=11 \mathrm{~Hz}, p$-Dipp'), $31.7\left(\left(C \mathrm{HMe}_{2}\right)_{\mathrm{Dipp}}\right), 29.8$

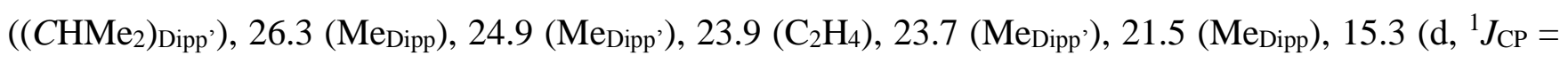
$\left.40 \mathrm{~Hz}, \mathrm{PMe}_{2}\right) .{ }^{31} \mathrm{P}\left\{{ }^{1} \mathrm{H}\right\} \mathrm{NMR}\left(160 \mathrm{MHz}, \mathrm{CD}_{2} \mathrm{Cl}_{2}, 25^{\circ} \mathrm{C}\right) \delta: 2.1$.

[Rh(CO)PMe2Ar'][BArF] (11·CO): To a solid mixture of complex $9(0.08 \mathrm{mmol})$ and $\mathrm{NaBAr}_{\mathrm{F}}(0.08$ mmol), placed in a thick-wall ampoule, was added $5 \mathrm{~mL}$ of $\mathrm{CH}_{2} \mathrm{Cl}_{2}$ and the resulting solution stirred for $10 \mathrm{~min}$. After filtering, the solvent was evaporated under reduced pressure and the solid obtained washed with pentane $(5 \mathrm{~mL})$. Complex 11. CO was isolated as a yellow powder in $c a$. $95 \%$ yield. Single crystals were grown at $-20{ }^{\circ} \mathrm{C}$ by slow diffusion of pentane into a $\mathrm{CH}_{2} \mathrm{Cl}_{2}$ solution (2:1 by vol.). 11a·CO: IR (Nujol): $2018 \mathrm{~cm}^{-1}$. Anal. Calc. for $\mathrm{C}_{57} \mathrm{H}_{39} \mathrm{BF}_{24} \mathrm{OPRh}$ : C, 51.1; H, 2.9. Found: C, 51.5; H, 2.6. ${ }^{1} \mathrm{H}$ NMR $\left(500 \mathrm{MHz}, 25{ }^{\circ} \mathrm{C}, \mathrm{CD}_{2} \mathrm{Cl}_{2}\right) \delta: 7.88\left(\mathrm{td},{ }^{3} J_{\mathrm{HH}}=7.6,{ }^{5} J_{\mathrm{HP}}=2.6 \mathrm{~Hz}, 1 \mathrm{H}, p-\mathrm{C}_{6} \mathrm{H}_{3}\right), 7.59(\mathrm{~d}$, $\left.{ }^{3} J_{\mathrm{HH}}=7.8 \mathrm{~Hz}, 1 \mathrm{H}, m^{\prime}-\mathrm{C}_{6} \mathrm{H}_{3}\right), 7.36\left(\mathrm{~m}, 2 \mathrm{H}, p-\mathrm{Xyl}, m-\mathrm{C}_{6} \mathrm{H}_{3}\right), 7.23\left(\mathrm{~d},{ }^{3} J_{\mathrm{HH}}=7.7 \mathrm{~Hz}, 2 \mathrm{H}, m-\mathrm{Xyl}\right), 7.09(\mathrm{~d}$, ${ }^{3} J_{\mathrm{HH}}=6.9 \mathrm{~Hz}, 2 \mathrm{H}, m-\mathrm{Xyl}$ '), $6.30\left(\mathrm{t},{ }^{3} J_{\mathrm{HH}}=6.7 \mathrm{~Hz}, 1 \mathrm{H}, p\right.$-Xyl'), 2.17 (s, 6H, Mexyl) $2.01(\mathrm{~s}, 6 \mathrm{H}, \mathrm{Mexyl})$, $1.56\left(\mathrm{~d},{ }^{2} J_{\mathrm{HP}}=11.9 \mathrm{~Hz}, 6 \mathrm{H}, \mathrm{PMe}_{2}\right) \cdot{ }^{13} \mathrm{C}\left\{{ }^{1} \mathrm{H}\right\} \mathrm{NMR}\left(125 \mathrm{MHz}, 25{ }^{\circ} \mathrm{C}, \mathrm{CD}_{2} \mathrm{Cl}_{2}\right) \delta: 183.2\left(\mathrm{dd},{ }^{1} J_{\mathrm{CRh}}=95\right.$, $\left.{ }^{2} J_{\mathrm{CP}}=19 \mathrm{~Hz}, \mathrm{CO}\right), 148.5\left(o-\mathrm{C}_{6} \mathrm{H}_{3}\right), 142.8\left(\mathrm{~d},{ }^{2} J_{\mathrm{CP}}=19 \mathrm{~Hz}, o-\mathrm{C}_{6} \mathrm{H}_{3}\right), 138.4\left(\mathrm{~d},{ }^{1} J_{\mathrm{CP}}=49 \mathrm{~Hz}\right.$, ipso- $\left.\mathrm{C}_{6} \mathrm{H}_{3}\right)$, $137.7(o-\mathrm{Xyl}), 135.2\left(p-\mathrm{C}_{6} \mathrm{H}_{3}\right), 133.8\left(\mathrm{~d},{ }^{3} J_{\mathrm{CP}}=7 \mathrm{~Hz}, m-\mathrm{C}_{6} \mathrm{H}_{3}\right), 130.5(p-\mathrm{Xyl}), 128.9(m-\mathrm{Xyl}), 128.8$ (d, $\left.{ }^{3} J_{\mathrm{CP}}=5 \mathrm{~Hz}, m^{\prime}-\mathrm{C}_{6} \mathrm{H}_{3}\right), 126.5$ (ipso-Xyl), 123.1 (o-Xyl'), 115.6 (ipso-Xyl'), 110.3 (m-Xyl'), 97.9 (d, ${ }^{1} J_{\mathrm{CRh}}=8 \mathrm{~Hz}, p$-Xyl'), $22.0\left(\mathrm{Me}_{\mathrm{Xyl}}\right), 20.3\left(\mathrm{Me}_{\mathrm{Xyl}}\right), 19.1\left(\mathrm{~d},{ }^{1} J_{\mathrm{CP}}=37 \mathrm{~Hz}, \mathrm{PMe}_{2}\right) .{ }^{31} \mathrm{P}\left\{{ }^{1} \mathrm{H}\right\} \mathrm{NMR}(200$ $\left.\mathrm{MHz}, 25{ }^{\circ} \mathrm{C}, \mathrm{CD}_{2} \mathrm{Cl}_{2}\right) \delta: 49.3\left(\mathrm{~d},{ }^{1} J_{\mathrm{PRh}}=169 \mathrm{~Hz}\right.$ ). 11b·CO: IR (Nujol): $2012 \mathrm{~cm}^{-1}$. Anal. Calc. for $\mathrm{C}_{65} \mathrm{H}_{55} \mathrm{BF}_{24} \mathrm{OPRh}: \mathrm{C}, 53.7 ; \mathrm{H}, 3.8$. Found: C, 53.2; H, 3.7. ${ }^{1} \mathrm{H}$ NMR $\left(500 \mathrm{MHz}, 25{ }^{\circ} \mathrm{C}, \mathrm{CD}_{2} \mathrm{Cl}_{2}\right) \delta: 7.83$ $\left(\mathrm{td},{ }^{3} J_{\mathrm{HH}}=7.6,{ }^{5} J_{\mathrm{HP}}=2.6 \mathrm{~Hz}, 1 \mathrm{H}, p-\mathrm{C}_{6} \mathrm{H}_{3}\right), 7.68\left(\mathrm{~d},{ }^{3} J_{\mathrm{HH}}=7.8 \mathrm{~Hz}, 1 \mathrm{H}, m^{\prime}-\mathrm{C}_{6} \mathrm{H}_{3}\right), 7.53\left(\mathrm{t},{ }^{3} J_{\mathrm{HH}}=7.8 \mathrm{~Hz}\right.$, $1 \mathrm{H}, p$-Dipp), $7.50\left(\mathrm{dd},{ }^{3} J_{\mathrm{HH}}=7.8,{ }^{4} J_{\mathrm{HP}}=3.6 \mathrm{~Hz}, 1 \mathrm{H}, m-\mathrm{C}_{6} \mathrm{H}_{3}\right), 7.34\left(\mathrm{~d},{ }^{3} J_{\mathrm{HH}}=7.9 \mathrm{~Hz}, 2 \mathrm{H}, m\right.$-Dipp), $7.10\left(\mathrm{~d},{ }^{3} J_{\mathrm{HH}}=6.9 \mathrm{~Hz}, 2 \mathrm{H}, m\right.$-Dipp'), $6.45\left(\mathrm{t},{ }^{3} J_{\mathrm{HH}}=6.8 \mathrm{~Hz}, 1 \mathrm{H}, p\right.$-Dipp'), $2.26\left(\mathrm{~h},{ }^{3} J_{\mathrm{HH}}=6.7 \mathrm{~Hz}, 4 \mathrm{H}\right.$, $\left.(\mathrm{CHMe})_{\text {Dipp }}\right), 1.54\left(\mathrm{~d},{ }^{2} J_{\mathrm{HP}}=11.9 \mathrm{~Hz}, 6 \mathrm{H}, \mathrm{PMe}_{2}\right), 1.33\left(\mathrm{~d},{ }^{3} J_{\mathrm{HH}}=6.9 \mathrm{~Hz}, 6 \mathrm{H}, \mathrm{Me}_{\mathrm{Dipp}}\right), 1.29\left(\mathrm{~d},{ }^{3} J_{\mathrm{HH}}=\right.$ $\left.6.8 \mathrm{~Hz}, 6 \mathrm{H}, \mathrm{Me}_{\text {Dipp }}\right), 1.26\left(\mathrm{~d},{ }^{3} J_{\mathrm{HH}}=6.8 \mathrm{~Hz}, 6 \mathrm{H}, \mathrm{Me}_{\text {Dipp }}\right), 1.05\left(\mathrm{~d},{ }^{3} J_{\mathrm{HH}}=6.6 \mathrm{~Hz}, 6 \mathrm{H}, \mathrm{Me}_{\text {Dipp }}\right) .{ }^{13} \mathrm{C}\left\{{ }^{1} \mathrm{H}\right\}$ 
NMR (125 MHz, $\left.25{ }^{\circ} \mathrm{C}, \mathrm{CD}_{2} \mathrm{Cl}_{2}\right) \delta: 182.7\left(\mathrm{dd},{ }^{1} J_{\mathrm{CRh}}=92,{ }^{2} J_{\mathrm{CP}}=18 \mathrm{~Hz}, \mathrm{CO}\right), 146.8$ (o-Dipp), 146.1 (o$\left.\mathrm{C}_{6} \mathrm{H}_{3}\right), 140.7\left(\mathrm{~d},{ }^{2} J_{\mathrm{CP}}=20 \mathrm{~Hz}, o-\mathrm{C}_{6} \mathrm{H}_{3}\right), 138.7\left(\mathrm{~d},{ }^{1} J_{\mathrm{CP}}=42 \mathrm{~Hz}\right.$, ipso- $\left.\mathrm{C}_{6} \mathrm{H}_{3}\right), 134.1\left(\mathrm{~d},{ }^{3} J_{\mathrm{CP}}=7 \mathrm{~Hz}, m^{\prime}-\right.$ $\mathrm{C}_{6} \mathrm{H}_{3}$ ), 133.1 (o-Dipp'), 132.3 ( $p-\mathrm{C}_{6} \mathrm{H}_{3}$ ), 130.5 (p-Dipp'), 128.3 (d, ${ }^{3} J_{\mathrm{CP}}=15 \mathrm{~Hz}, m-\mathrm{C}_{6} \mathrm{H}_{3}$ ), 127.8 (ipso-

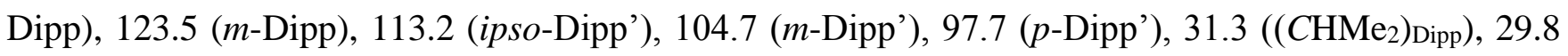

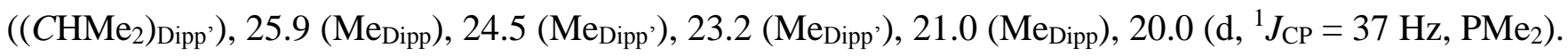
${ }^{31} \mathrm{P}\left\{{ }^{1} \mathrm{H}\right\}$ NMR $\left(200 \mathrm{MHz}, 25{ }^{\circ} \mathrm{C}, \mathrm{CD}_{2} \mathrm{Cl}_{2}\right) \delta: 49.2\left(\mathrm{~d},{ }^{1} J_{\mathrm{PRh}}=167 \mathrm{~Hz}\right)$.

[Ir(CO) $\left.)_{2} \mathbf{P M e}_{2} \mathrm{Ar} \mathbf{r}^{\prime}\right][\mathrm{BArF}]\left(\mathbf{1 2} \cdot(\mathbf{C O})_{2}\right)$ : To a solid mixture of complex $10(0.02 \mathrm{mmol})$ and $\mathrm{NaBAr}_{\mathrm{F}}$ (0.02 mmol), placed in a thick-wall ampoule, was added $0.7 \mathrm{~mL}$ of cold $\left(\mathbf{a},-78{ }^{\circ} \mathrm{C} ; \mathbf{b},-30{ }^{\circ} \mathrm{C}\right) \mathrm{CD}_{2} \mathrm{Cl}_{2}$ and the resulting solution kept cold and stirred for $30 \mathrm{~min}$. The solution was filtered with cannula over an NMR tube placed in a dry ice/acetone bath. The spectroscopic data for this compound were collected at low temperature $\left(-60^{\circ} \mathrm{C}, \mathbf{a} ; 0^{\circ} \mathrm{C}, \mathbf{b}\right)$ for preventing $\mathrm{CO}$ liberation. The yield is estimated to be quantitative based on spectroscopic data. Analitically pure samples of this compound were obtained evaporating the solvent and washing with pentane at low temperature. IR data were collected from freshly prepared, cold $\mathrm{CH}_{2} \mathrm{Cl}_{2}$ solutions. 12a·(CO)2: IR $\left(\mathrm{CH}_{2} \mathrm{Cl}_{2}\right)$ : v(Ir-CO) 2094, $2027 \mathrm{~cm}^{-1}$. Anal. Calcd. for $\mathrm{C}_{58} \mathrm{H}_{39} \mathrm{BF}_{24} \mathrm{IrO}_{2} \mathrm{P}: \mathrm{C}, 47.78$; H, 2.70. Found: C, 47.70; H, 2.26. ${ }^{1} \mathrm{H}$ NMR (400 MHz, $\mathrm{CD}_{2} \mathrm{Cl}_{2}$, $\left.-60{ }^{\circ} \mathrm{C}\right) \delta: 7.77\left(\mathrm{~d},{ }^{3} J_{\mathrm{HH}}=c a .7 .6 \mathrm{~Hz}, 2 \mathrm{H}, m-\mathrm{Xyl}\right.$ ) $), 7.74(\mathrm{~s}, 8 \mathrm{H}, o-\mathrm{Ar}), 7.68\left(\mathrm{t},{ }^{3} J_{\mathrm{HH}}=7.5 \mathrm{~Hz}, 1 \mathrm{H}, p-\right.$ $\left.\mathrm{C}_{6} \mathrm{H}_{3}\right), 7.54\left(\mathrm{~s}, 4 \mathrm{H}, p\right.$-Ar), $7.28\left(\mathrm{t},{ }^{3} J_{\mathrm{HH}}=7.6 \mathrm{~Hz}, 2 \mathrm{H}, p\right.$-Xyl, $p$-Xyl'), $7.22\left(\mathrm{dd},{ }^{3} J_{\mathrm{HH}}=7.0 \mathrm{~Hz},{ }^{4} J_{\mathrm{HP}}=2.4\right.$ $\left.\mathrm{Hz}, 1 \mathrm{H}, m-\mathrm{C}_{6} \mathrm{H}_{3}\right), 7.16\left(\mathrm{~d},{ }^{3} J_{\mathrm{HH}}=7.5 \mathrm{~Hz}, 2 \mathrm{H}, m-\mathrm{Xyl}\right), 6.62\left(\mathrm{~d},{ }^{3} J_{\mathrm{HH}}=6.8 \mathrm{~Hz}, 1 \mathrm{H}, m^{\prime}-\mathrm{C}_{6} \mathrm{H}_{3}\right), 2.05(\mathrm{~s}, 6 \mathrm{H}$, $\left.\mathrm{MeXyl}^{\prime}\right), 1.94(\mathrm{~s}, 6 \mathrm{H}, \mathrm{Mexyl}), 1.60\left(\mathrm{~d},{ }^{2} J_{\mathrm{HP}}=10.6 \mathrm{~Hz}, 6 \mathrm{H}, \mathrm{PMe}_{2}\right) .{ }^{13} \mathrm{C}\left\{{ }^{1} \mathrm{H}\right\} \mathrm{NMR}\left(100 \mathrm{MHz}, \mathrm{CD}_{2} \mathrm{Cl}_{2},-60\right.$ $\left.{ }^{\circ} \mathrm{C}\right) \delta: 183.0\left(\mathrm{~d},{ }^{2} J_{\mathrm{CP}}=102 \mathrm{~Hz}\right.$, trans-CO), $162.4\left(\mathrm{~d},{ }^{2} J_{\mathrm{CP}}=14 \mathrm{~Hz}\right.$, cis-CO), $161.4\left(\mathrm{q},{ }^{1} J_{\mathrm{CB}}=49 \mathrm{~Hz}\right.$, ipsoAr), $147.2\left(o-\mathrm{C}_{6} \mathrm{H}_{3}\right), 143.9\left(\mathrm{~d},{ }^{2} J_{\mathrm{CP}}=27 \mathrm{~Hz}, o-\mathrm{C}_{6} \mathrm{H}_{3}\right), 139.1$ (o-Xyl'), 136.2 (ipso-Xyl, o-Xyl), 135.6 (p$\mathrm{C}_{6} \mathrm{H}_{3}$ ), 134.3 (o-Ar), 134.2 (m-Xyl'), 133.2 ( $p$-Xyl or $p$-Xyl'), 132.1 (d, $\left.{ }^{3} J_{\mathrm{CP}}=6 \mathrm{~Hz}, m-\mathrm{C}_{6} \mathrm{H}_{3}\right), 130.7$ (d, $\left.{ }^{3} J_{\mathrm{CP}}=15 \mathrm{~Hz}, m^{\prime}-\mathrm{C}_{6} \mathrm{H}_{3}\right), 129.7\left(\mathrm{~d},{ }^{1} J_{\mathrm{CP}}=56 \mathrm{~Hz}\right.$, ipso- $\left.\mathrm{C}_{6} \mathrm{H}_{3}\right), 129.1\left(p-\mathrm{Xyl}\right.$ or $\left.p-\mathrm{Xyl}{ }^{\prime}\right), 128.3\left(\mathrm{q},{ }^{2} J_{\mathrm{CF}}=31\right.$ $\mathrm{Hz}, m$-Ar), 127.5 ( $m$-Xyl), 124.1 (q, $\left.{ }^{1} J_{\mathrm{CF}}=272 \mathrm{~Hz}, \mathrm{CF}_{3}\right), 117.4\left(\mathrm{~d},{ }^{2} J_{\mathrm{CP}}=3 \mathrm{~Hz}\right.$, ipso-Xyl'), $117.2(\mathrm{~m}, p-$ Ar), $23.6\left(\mathrm{MeXyl}^{\prime}\right), 21.0\left(\mathrm{Me}_{\mathrm{Xyl}}\right), 14.4\left(\mathrm{~d},{ }^{1} J_{\mathrm{CP}}=40 \mathrm{~Hz}, \mathrm{PMe}_{2}\right) .{ }^{31} \mathrm{P}\left\{{ }^{1} \mathrm{H}\right\} \mathrm{NMR}\left(160 \mathrm{MHz}, \mathrm{CD}_{2} \mathrm{Cl}_{2},-60\right.$ $\left.{ }^{\circ} \mathrm{C}\right) \delta:$ 16.2. 12b· $(\mathbf{C O})_{2}: \mathrm{IR}\left(\mathrm{CH}_{2} \mathrm{Cl}_{2}\right): v(\mathrm{Ir}-\mathrm{CO}) 2093,2027 \mathrm{~cm}^{-1}$. Anal. Calcd. for $\mathrm{C}_{66} \mathrm{H}_{55} \mathrm{BF}_{24} \mathrm{IrO}_{2} \mathrm{P}: \mathrm{C}$, 50.49; H, 3.53. Found: C, 50.57; H, 3.47. ${ }^{1} \mathrm{H} \mathrm{NMR}\left(500 \mathrm{MHz}, \mathrm{CD}_{2} \mathrm{Cl}_{2}, 25{ }^{\circ} \mathrm{C}\right) \delta: 7.99\left(\mathrm{~d},{ }^{3} \mathrm{~J}_{\mathrm{HH}}=7.8 \mathrm{~Hz}\right.$, 2H, m-Dipp'),7.72 (s, 8H,o-Ar), 7.69 (m, 1H, $p$ - $\left.\mathrm{C}_{6} \mathrm{H}_{3}\right), 7.59$ (t, ${ }^{3} J_{\mathrm{HH}}=7.7 \mathrm{~Hz}, 1 \mathrm{H}, p$-Dipp'), 7.56 (s, 4H, $p$-Ar), $7.54\left(\mathrm{t},{ }^{3} J_{\mathrm{HH}}=8.0 \mathrm{~Hz}, 1 \mathrm{H}, p\right.$-Dipp), $7.43\left(\mathrm{dd},{ }^{3} J_{\mathrm{HH}}=7.4 \mathrm{~Hz},{ }^{4} J_{\mathrm{HP}}=3.1 \mathrm{~Hz}, 1 \mathrm{H}, m-\mathrm{C}_{6} \mathrm{H}_{3}\right), 7.35(\mathrm{~d}$, ${ }^{3} J_{\mathrm{HH}}=7.8 \mathrm{~Hz}, 2 \mathrm{H}, m$-Dipp), $6.79\left(\mathrm{~d},{ }^{3} J_{\mathrm{HH}}=7.6 \mathrm{~Hz}, 1 \mathrm{H}, m^{\prime}-\mathrm{C}_{6} \mathrm{H}_{3}\right), 2.28\left(\mathrm{~h},{ }^{3} J_{\mathrm{HH}}=6.8 \mathrm{~Hz}, 4 \mathrm{H}\right.$, $\left.\left(\mathrm{CHMe}_{2}\right)_{\text {Dipp }},(\mathrm{CHMe})_{\text {Dipp }}\right), 1.64\left(\mathrm{~d},{ }^{2} J_{\mathrm{HP}}=10.7 \mathrm{~Hz}, 6 \mathrm{H}, \mathrm{PMe}_{2}\right), 1.56\left(\mathrm{~d},{ }^{3} J_{\mathrm{HH}}=6.9 \mathrm{~Hz}, 6 \mathrm{H}, \mathrm{Me}_{\text {Dipp }}\right)$, $1.31\left(\mathrm{~d},{ }^{3} J_{\mathrm{HH}}=6.8,6 \mathrm{H}, \mathrm{Me}_{\text {Dipp }}\right), 1.05\left(\mathrm{~d},{ }^{3} J_{\mathrm{HH}}=6.6 \mathrm{~Hz}, 6 \mathrm{H}, \mathrm{Me}_{\mathrm{Dipp}}{ }^{\prime}\right), 1.03\left(\mathrm{~d},{ }^{3} J_{\mathrm{HH}}=6.8 \mathrm{~Hz}, 6 \mathrm{H}\right.$, Me $\left.{ }_{\text {Dipp }}\right) .{ }^{13} \mathrm{C}\left\{{ }^{1} \mathrm{H}\right\}$ NMR $\left(100 \mathrm{MHz}, \mathrm{CD}_{2} \mathrm{Cl}_{2}, 0{ }^{\circ} \mathrm{C}\right) \delta: 183.0\left(\mathrm{~d},{ }^{2} J_{\mathrm{CP}}=102 \mathrm{~Hz}\right.$, trans-CO), $163.4\left(\mathrm{~d},{ }^{2} J_{\mathrm{CP}}\right.$ $=14 \mathrm{~Hz}$, cis-CO), 162.0 (q, ${ }^{1} J_{\mathrm{CB}}=50 \mathrm{~Hz}$, ipso-Ar), 150.6 (o-Dipp'), 147.1 (o-Dipp), $146.5\left(\mathrm{~d},{ }^{2} J_{\mathrm{CP}}=2\right.$ 
$\left.\mathrm{Hz}, o-\mathrm{C}_{6} \mathrm{H}_{3}\right), 142.5\left(\mathrm{~d},{ }^{2} J_{\mathrm{CP}}=26 \mathrm{~Hz}, o-\mathrm{C}_{6} \mathrm{H}_{3}\right), 135.0$ (o-Ar), 134.6 (p-Dipp'), 134.24 (d, ${ }^{3} J_{\mathrm{CP}}=9 \mathrm{~Hz}, m^{-}$ $\left.\mathrm{C}_{6} \mathrm{H}_{3}\right), 134.22\left(p-\mathrm{C}_{6} \mathrm{H}_{3}\right), 133.8\left(\mathrm{~d},{ }^{3} J_{\mathrm{CP}}=2 \mathrm{~Hz}\right.$, ipso-Dipp), $132.4\left(\mathrm{~d},{ }^{3} J_{\mathrm{CP}}=15 \mathrm{~Hz}, m^{\prime}-\mathrm{C}_{6} \mathrm{H}_{3}\right), 132.1(\mathrm{~d}$, ${ }^{1} J_{\mathrm{CP}}=57 \mathrm{~Hz}$, ipso- $\left.\mathrm{C}_{6} \mathrm{H}_{3}\right), 131.3$ ( $m$-Dipp'), 130.8 (p-Dipp), 129.0 (q, ${ }^{2} J_{\mathrm{CF}}=31 \mathrm{~Hz}, m$-Ar), 124.8 (q, ${ }^{1} J_{\mathrm{CF}}$ $\left.=272 \mathrm{~Hz}, \mathrm{CF}_{3}\right), 123.6$ (m-Dipp), 118.1 (d, ${ }^{2} J_{\mathrm{CP}}=3 \mathrm{~Hz}$, ipso-Dipp'), 117.7 (m, p-Ar), 34.6

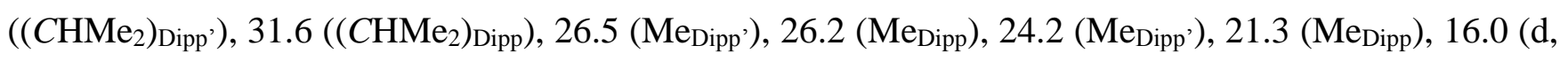
$\left.{ }^{1} J_{\mathrm{CP}}=40 \mathrm{~Hz}, \mathrm{PMe}_{2}\right) .{ }^{31} \mathrm{P}\left\{{ }^{1} \mathrm{H}\right\} \mathrm{NMR}\left(160 \mathrm{MHz}, \mathrm{CD}_{2} \mathrm{Cl}_{2}, 25{ }^{\circ} \mathrm{C}\right) \delta: 15.2$.

[Ir(CO)PMe2Ar'][BArF] (12.CO): To a solid mixture of complex $10(0.04 \mathrm{mmol})$ and $\mathrm{NaBAr}_{\mathrm{F}}(0.04$ mmol), placed in a thick-wall ampoule, was added $5 \mathrm{~mL}$ of $\mathrm{CH}_{2} \mathrm{Cl}_{2}$ and the resulting solution stirred for $10 \mathrm{~min}$. The solution was filtered, kept under reflux and periodically opened to vacuum until CO liberation was complete. Solvent was removed under reduced pressure and the product washed with pentane to yield an air-stable, analytically pure yellow powder in $c a .85 \%$ yield. Single crystals suitable for X-Ray diffraction were grown by means of slow pentane diffusion in a dichloromethane solution of the complex at $-32{ }^{\circ} \mathrm{C}$. This compound was also obtained pure allowing a dichloromethane solution of 12.(CO)2 to stand in an open-air NMR tube for several days. 12a· CO: IR (Nujol): v(Ir-CO) $2000 \mathrm{~cm}^{-1}$. Anal. Calcd. for $\mathrm{C}_{57} \mathrm{H}_{39} \mathrm{BF}_{24} \mathrm{IrOP}: \mathrm{C}, 47.88$; H, 2.75. Found: C, 47.89; H, 2.40. ${ }^{1} \mathrm{H} \mathrm{NMR}(400 \mathrm{MHz}$, $\left.\mathrm{CD}_{2} \mathrm{Cl}_{2}, 25^{\circ} \mathrm{C}\right) \delta: 7.83\left(\mathrm{~m}, 1 \mathrm{H}, p-\mathrm{C}_{6} \mathrm{H}_{3}\right), 7.73$ (s, 8H,o-Ar), $7.60\left(\mathrm{~m}, 1 \mathrm{H}, m^{\prime}-\mathrm{C}_{6} \mathrm{H}_{3}\right), 7.57$ (s, 4H, $p$-Ar), $7.34\left(\mathrm{t},{ }^{3} J_{\mathrm{HH}}=7.7 \mathrm{~Hz}, 1 \mathrm{H}, p-\mathrm{Xyl}\right), 7.31\left(\mathrm{~m}, 1 \mathrm{H}, m-\mathrm{C}_{6} \mathrm{H}_{3}\right), 7.20\left(\mathrm{~d},{ }^{3} J_{\mathrm{HH}}=7.6 \mathrm{~Hz}, 2 \mathrm{H}, m-\mathrm{Xyl}\right), 7.04(\mathrm{~d}$, ${ }^{3} J_{\mathrm{HH}}=6.4 \mathrm{~Hz}, 2 \mathrm{H}, m-\mathrm{Xyl}$ '), $6.09\left(\mathrm{t},{ }^{3} J_{\mathrm{HH}}=6.5 \mathrm{~Hz}, 1 \mathrm{H}, p-\mathrm{Xyl}\right.$ ') $2.26\left(\mathrm{~s}, 6 \mathrm{H}, \mathrm{MeXyl}^{\prime}\right), 1.97(\mathrm{~s}, 6 \mathrm{H}, \mathrm{Me} \mathrm{Xyl})$, $1.70\left(\mathrm{~d},{ }^{2} J_{\mathrm{HP}}=12.1 \mathrm{~Hz}, 6 \mathrm{H}, \mathrm{PMe}_{2}\right) .{ }^{13} \mathrm{C}\left\{{ }^{1} \mathrm{H}\right\} \mathrm{NMR}\left(100 \mathrm{MHz}, \mathrm{CD}_{2} \mathrm{Cl}_{2}, 25{ }^{\circ} \mathrm{C}\right) \delta: 167.2\left(\mathrm{~d},{ }^{2} J_{\mathrm{CP}}=14 \mathrm{~Hz}\right.$, $\mathrm{CO}), 162.2\left(\mathrm{q},{ }^{1} J_{\mathrm{CB}}=50 \mathrm{~Hz}\right.$, ipso-Ar), $148.9\left(\mathrm{~d},{ }^{2} J_{\mathrm{CP}}=3 \mathrm{~Hz}, o-\mathrm{C}_{6} \mathrm{H}_{3}\right), 141.3\left(\mathrm{~d},{ }^{2} J_{\mathrm{CP}}=18 \mathrm{~Hz}, o-\mathrm{C}_{6} \mathrm{H}_{3}\right)$, $139.2\left(\mathrm{~d},{ }^{1} J_{\mathrm{CP}}=58 \mathrm{~Hz}\right.$, ipso- $\left.\mathrm{C}_{6} \mathrm{H}_{3}\right), 136.9\left(\mathrm{~d},{ }^{3} J_{\mathrm{CP}}=3 \mathrm{~Hz}\right.$, ipso-Xyl), $136.7(o-\mathrm{Xyl}), 135.2(o-\mathrm{Ar}), 134.7$ $\left(\mathrm{d},{ }^{4} J_{\mathrm{CP}}=2 \mathrm{~Hz}, p-\mathrm{C}_{6} \mathrm{H}_{3}\right), 133.6\left(\mathrm{~d},{ }^{3} J_{\mathrm{CP}}=8 \mathrm{~Hz}, m-\mathrm{C}_{6} \mathrm{H}_{3}\right), 130.0(p-\mathrm{Xyl}), 129.3\left(\mathrm{q},{ }^{2} J_{\mathrm{CF}}=32 \mathrm{~Hz}, m-\mathrm{Ar}\right)$, $128.5(m-\mathrm{Xyl}), 128.4\left(\mathrm{~d},{ }^{3} J_{\mathrm{CP}}=14 \mathrm{~Hz}, m^{\prime}-\mathrm{C}_{6} \mathrm{H}_{3}\right), 125.0\left(\mathrm{q},{ }^{1} J_{\mathrm{CF}}=272 \mathrm{~Hz}, \mathrm{CF}_{3}\right), 117.9$ (m, $\left.p-\mathrm{Ar}\right), 116.9$ $\left(\mathrm{d},{ }^{2} J_{\mathrm{CP}}=2 \mathrm{~Hz}, o\right.$-Xyl'), $109.7\left(\mathrm{~d},{ }^{2} J_{\mathrm{CP}}=5 \mathrm{~Hz}\right.$, ipso-Xyl'), $103.0\left(\mathrm{~d},{ }^{2} J_{\mathrm{CP}}=3 \mathrm{~Hz}, m-\mathrm{Xyl}\right.$ '), $89.1\left(\mathrm{~d},{ }^{2} J_{\mathrm{CP}}\right.$ $=7 \mathrm{~Hz}, p$-Xyl'), $21.4\left(\mathrm{Me}_{\mathrm{Xyl}}\right), 19.4\left(\mathrm{MeXyl}^{\prime}\right), 19.3\left(\mathrm{~d},{ }^{1} J_{\mathrm{CP}}=43 \mathrm{~Hz}, \mathrm{PMe}_{2}\right) .{ }^{31} \mathrm{P}\left\{{ }^{1} \mathrm{H}\right\} \mathrm{NMR}(160 \mathrm{MHz}$, $\mathrm{CD}_{2} \mathrm{Cl}_{2}, 25^{\circ} \mathrm{C}$ ) $\delta$ : 6.7. 12b·CO: IR (Nujol): v(Ir-CO) $1997 \mathrm{~cm}^{-1}$. Anal. Calcd. for $\mathrm{C}_{65} \mathrm{H}_{55} \mathrm{BF}_{24} \mathrm{IrOP}: \mathrm{C}$, 50.63; H, 3.60. Found: C, 50.35; H, 3.47. $\left.{ }^{1} \mathrm{H} \mathrm{NMR} \mathrm{(400} \mathrm{MHz,} \mathrm{CD}_{2} \mathrm{Cl}_{2}, 25{ }^{\circ} \mathrm{C}\right) \delta: 7.77\left(\mathrm{td},{ }^{3} J_{\mathrm{HH}}=7.6 \mathrm{~Hz}\right.$, $\left.{ }^{5} J_{\mathrm{HP}}=2.4 \mathrm{~Hz}, 1 \mathrm{H}, p-\mathrm{C}_{6} \mathrm{H}_{3}\right), 7.72(\mathrm{~s}, 8 \mathrm{H}, o-\mathrm{Ar}), 7.69\left(\mathrm{ddd},{ }^{3} J_{\mathrm{HH}}=7.6 \mathrm{~Hz},{ }^{4} J_{\mathrm{HP}}=2.3 \mathrm{~Hz},{ }^{4} J_{\mathrm{HH}}=1.2 \mathrm{~Hz}\right.$, $\left.1 \mathrm{H}, m^{\prime}-\mathrm{C}_{6} \mathrm{H}_{3}\right), 7.56(\mathrm{~s}, 4 \mathrm{H}, p-\mathrm{Ar}), 7.50\left(\mathrm{t},{ }^{3} J_{\mathrm{HH}}=7.8 \mathrm{~Hz}, 1 \mathrm{H}, p\right.$-Dipp$), 7.44\left(\mathrm{ddd},{ }^{3} J_{\mathrm{HH}}=7.5 \mathrm{~Hz},{ }^{4} J_{\mathrm{HP}}=\right.$ $\left.3.8 \mathrm{~Hz},{ }^{4} J_{\mathrm{HH}}=1.1 \mathrm{~Hz}, 1 \mathrm{H}, m-\mathrm{C}_{6} \mathrm{H}_{3}\right), 7.30\left(\mathrm{~d},{ }^{3} J_{\mathrm{HH}}=7.8 \mathrm{~Hz}, 2 \mathrm{H}, m-\mathrm{Dipp}\right), 7.04\left(\mathrm{dd},{ }^{3} J_{\mathrm{HH}}=6.6 \mathrm{~Hz},{ }^{3} J_{\mathrm{HP}}\right.$ $=0.9 \mathrm{~Hz}, 2 \mathrm{H}, m$-Dipp'), $6.24\left(\mathrm{t},{ }^{3} J_{\mathrm{HH}}=6.6 \mathrm{~Hz}, 1 \mathrm{H}, p\right.$-Dipp'), $2.19\left(\mathrm{~h},{ }^{3} J_{\mathrm{HH}}=6.6 \mathrm{~Hz}, 4 \mathrm{H},(\mathrm{CHMe})_{\text {Dipp }}\right.$, $\left.\left(\mathrm{CHMe}_{2}\right)_{\text {Dipp }}\right), 1.67\left(\mathrm{~d},{ }^{2} J_{\mathrm{HP}}=12.1 \mathrm{~Hz}, 6 \mathrm{H}, \mathrm{PMe} 2\right), 1.33\left(\mathrm{~d},{ }^{3} J_{\mathrm{HH}}=6.9 \mathrm{~Hz}, 6 \mathrm{H}, \mathrm{Me}_{\mathrm{Dipp}}\right), 1.26\left(\mathrm{~d},{ }^{3} J_{\mathrm{HH}}=\right.$ $\left.6.7 \mathrm{~Hz}, 6 \mathrm{H}, \mathrm{Me}_{\text {Dipp }}\right), 1.25\left(\mathrm{~d},{ }^{3} \mathrm{~J}_{\mathrm{HH}}=6.7 \mathrm{~Hz}, 6 \mathrm{H}, \mathrm{Me}\right.$ Dipp $), 1.02\left(\mathrm{~d},{ }^{3} \mathrm{~J}_{\mathrm{HH}}=6.6 \mathrm{~Hz}, 6 \mathrm{H}, \mathrm{Me}\right.$ Dipp $) .{ }^{13} \mathrm{C}\left\{{ }^{1} \mathrm{H}\right\}$ NMR $\left(100 \mathrm{MHz}, \mathrm{CD}_{2} \mathrm{Cl}_{2}, 25{ }^{\circ} \mathrm{C}\right) \delta: 167.7\left(\mathrm{~d},{ }^{2} J_{\mathrm{CP}}=14 \mathrm{~Hz}, \mathrm{CO}\right), 162.2\left(\mathrm{q},{ }^{1} J_{\mathrm{CB}}=50 \mathrm{~Hz}\right.$, ipso-Ar), 147.3 
(o-Dipp), $147.2\left(\mathrm{~d},{ }^{2} \mathrm{~J}_{\mathrm{CP}}=3 \mathrm{~Hz}, o-\mathrm{C}_{6} \mathrm{H}_{3}\right), 140.6\left(\mathrm{~d},{ }^{1} J_{\mathrm{CP}}=58 \mathrm{~Hz}\right.$, ipso- $\left.\mathrm{C}_{6} \mathrm{H}_{3}\right), 140.4\left(\mathrm{~d},{ }^{2} J_{\mathrm{CP}}=18 \mathrm{~Hz}, o-\right.$ $\left.\mathrm{C}_{6} \mathrm{H}_{3}\right), 135.3$ (o-Ar), $134.9\left(\mathrm{~d},{ }^{3} J_{\mathrm{CP}}=8 \mathrm{~Hz}, m-\mathrm{C}_{6} \mathrm{H}_{3}\right), 134.4\left(\mathrm{~d},{ }^{3} J_{\mathrm{CP}}=3 \mathrm{~Hz}\right.$, ipso-Dipp), $132.7\left(\mathrm{~d},{ }^{4} J_{\mathrm{CP}}=\right.$ $\left.2 \mathrm{~Hz}, p-\mathrm{C}_{6} \mathrm{H}_{3}\right), 131.0$ (p-Dipp), 129.3 (q, $\left.{ }^{2} J_{\mathrm{CF}}=31 \mathrm{~Hz}, m-\mathrm{Ar}\right), 128.9$ (d, $\left.{ }^{3} J_{\mathrm{CP}}=14 \mathrm{~Hz}, m^{\prime}-\mathrm{C}_{6} \mathrm{H}_{3}\right), 127.7$ $\left(\mathrm{d},{ }^{2} J_{\mathrm{CP}}=2 \mathrm{~Hz}, o\right.$-Dipp'), 125.1 (q, $\left.{ }^{1} J_{\mathrm{CF}}=272 \mathrm{~Hz}, \mathrm{CF}_{3}\right), 123.7$ (m-Dipp), 117.9 (m, $p$-Ar), $108.4\left(\mathrm{~d},{ }^{2} J_{\mathrm{CP}}\right.$ $=5 \mathrm{~Hz}$, ipso-Xyl'), 98.4 (d, ${ }^{2} J_{\mathrm{CP}}=3 \mathrm{~Hz}, m$-Dipp'), 90.0 (d, ${ }^{2} J_{\mathrm{CP}}=7 \mathrm{~Hz}, p$-Dipp'), $31.8\left(\left(C \mathrm{HMe}_{2}\right)_{\mathrm{Dipp}}\right)$, $\left.29.9\left(\mathrm{CHMe}_{2}\right)_{\text {Dipp }}\right), 26.4\left(\mathrm{Me}_{\text {Dipp }}\right), 24.8\left(\mathrm{Me}_{\text {Dipp }}\right), 23.7\left(\mathrm{Me}_{\text {Dipp }}\right), 21.5\left(\mathrm{Me}_{\text {Dipp }}\right), 21.3\left(\mathrm{~d},{ }^{1} J_{\mathrm{CP}}=44 \mathrm{~Hz}\right.$, $\left.\mathrm{PMe}_{2}\right) .{ }^{31} \mathrm{P}\left\{{ }^{1} \mathrm{H}\right\} \mathrm{NMR}\left(160 \mathrm{MHz}, \mathrm{CD}_{2} \mathrm{Cl}_{2}, 25^{\circ} \mathrm{C}\right) \delta: 6.1$.

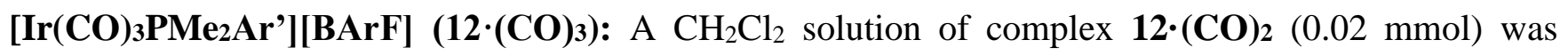
placed in a thick-wall ampoule, charged with 1.2 bar of $\mathrm{CO}$ and stirred for $10 \mathrm{~min}$. The solvent was removed under reduced pressure and the product washed with pentane to yield an analytically pure yellow powder in $c a$. $85 \%$ yield. Single crystals suitable for X-Ray diffraction were grown through slow pentane diffusion in a dichloromethane solution of the complex at $-32{ }^{\circ} \mathrm{C}$. The product can also be obtained starting from complex 12·(CO). 12a-(CO) $)_{3}$ IR $\left(\mathrm{CH}_{2} \mathrm{Cl}_{2}\right)$ : v(Ir-CO) 2126, $2027 \mathrm{~cm}^{-1}$. Anal. Calcd. for $\mathrm{C}_{59} \mathrm{H}_{39} \mathrm{BF}_{24} \mathrm{IrO}_{3} \mathrm{P}: \mathrm{C}, 47.69 ; \mathrm{H}, 2.65$. Found: C, 47.66; H, 2.19. ${ }^{1} \mathrm{H}$ NMR (400 MHz, $\mathrm{CD}_{2} \mathrm{Cl}_{2}$, $\left.25{ }^{\circ} \mathrm{C}\right) \delta: 7.74(\mathrm{~s}, 8 \mathrm{H}, o-\mathrm{Ar}), 7.71\left(\mathrm{t},{ }^{3} \mathrm{~J}_{\mathrm{HH}}=7.2 \mathrm{~Hz}, 1 \mathrm{H}, p-\mathrm{C}_{6} \mathrm{H}_{3}\right), 7.58(\mathrm{~s}, 4 \mathrm{H}, p-\mathrm{Ar}), 7.47\left(\mathrm{t},{ }^{3} \mathrm{~J}_{\mathrm{HH}}=7.6\right.$ $\mathrm{Hz}, 2 \mathrm{H}, p-\mathrm{Xyl}), 7.24\left(\mathrm{~d},{ }^{3} \mathrm{~J}_{\mathrm{HH}}=7.5 \mathrm{~Hz}, 4 \mathrm{H}, m-\mathrm{Xyl}\right), 6.97$ (br, 2H, $\left.m-\mathrm{C}_{6} \mathrm{H}_{3}\right), 2.11$ (s, 12H, Mexyl), 1.93 (d, $\left.{ }^{2} \mathrm{~J}_{\mathrm{HP}}=10.9 \mathrm{~Hz}, 6 \mathrm{H}, \mathrm{PMe}_{2}\right) \cdot{ }^{13} \mathrm{C}\left\{{ }^{1} \mathrm{H}\right\} \mathrm{NMR}\left(100 \mathrm{MHz}, \mathrm{CD}_{2} \mathrm{Cl}_{2}, 25{ }^{\circ} \mathrm{C}\right) \delta: 173.1\left(\mathrm{~d},{ }^{2} J_{\mathrm{CP}}=15 \mathrm{~Hz}\right.$, cis-CO), $168.2\left(\mathrm{~d},{ }^{2} J_{\mathrm{CP}}=88 \mathrm{~Hz}\right.$, trans-CO), $162.2\left(\mathrm{q},{ }^{1} J_{\mathrm{CB}}=50 \mathrm{~Hz}\right.$, ipso-Ar), $147.4\left(\mathrm{~d},{ }^{2} J_{\mathrm{CP}}=12 \mathrm{~Hz}, o-\mathrm{C}_{6} \mathrm{H}_{3}\right)$, $140.1(o-\mathrm{Xyl}), 135.6\left(\mathrm{~d},{ }^{4} J_{\mathrm{CP}}=2 \mathrm{~Hz}, p-\mathrm{C}_{6} \mathrm{H}_{3}\right), 135.2$ (o-Ar), 132.3 (br, ipso-Xyl), $132.1\left(\mathrm{~d},{ }^{3} J_{\mathrm{CP}}=10 \mathrm{~Hz}\right.$, $\left.m-\mathrm{C}_{6} \mathrm{H}_{3}\right), 131.0(p-\mathrm{Xyl}), 130.4\left(\mathrm{~d},{ }^{1} J_{\mathrm{CP}}=58 \mathrm{~Hz}\right.$, ipso- $\left.\mathrm{C}_{6} \mathrm{H}_{3}\right), 129.3\left(\mathrm{q},{ }^{2} J_{\mathrm{CF}}=31 \mathrm{~Hz}, m-\mathrm{Ar}\right), 128.7(m-$ $\mathrm{Xyl}), 125.0\left(\mathrm{q},{ }^{1} J_{\mathrm{CF}}=272 \mathrm{~Hz}, \mathrm{CF}_{3}\right), 117.9$ (m, p-Ar), $21.9\left(\mathrm{Me}_{\mathrm{Xyl}}\right), 18.1\left(\mathrm{~d},{ }^{1} J_{\mathrm{CP}}=43 \mathrm{~Hz}, \mathrm{PMe}_{2}\right)$. ${ }^{31} \mathrm{P}\left\{{ }^{1} \mathrm{H}\right\}$ NMR $\left(160 \mathrm{MHz}, \mathrm{CD}_{2} \mathrm{Cl}_{2}, 25{ }^{\circ} \mathrm{C}\right) \delta:-20.2$. 12b・(CO)3: IR $\left(\mathrm{CH}_{2} \mathrm{Cl}_{2}\right): v(\operatorname{Ir}-\mathrm{CO}) 2125,2025 \mathrm{~cm}^{-1}$. Anal. Calcd. for $\mathrm{C}_{67} \mathrm{H}_{55} \mathrm{BF}_{24} \mathrm{IrO}_{3} \mathrm{P}$ : C, 50.35; H, 3.47. Found: C, 50.47; H, 3.04. ${ }^{1} \mathrm{H}$ NMR (400 MHz, $\left.\mathrm{CD}_{2} \mathrm{Cl}_{2}, 0{ }^{\circ} \mathrm{C}\right) \delta: 7.71(\mathrm{~s}, 8 \mathrm{H}, o-\mathrm{Ar}), 7.64\left(\mathrm{td},{ }^{3} \mathrm{~J}_{\mathrm{HH}}=7.7 \mathrm{~Hz},{ }^{5} \mathrm{~J}_{\mathrm{HP}}=2.2 \mathrm{~Hz}, 1 \mathrm{H}, p-\mathrm{C}_{6} \mathrm{H}_{3}\right), 7.60\left(\mathrm{t},{ }^{3} \mathrm{~J}_{\mathrm{HH}}=\right.$ $7.8 \mathrm{~Hz}, 2 \mathrm{H}, p$-Dipp), 7.56 (s, 4H, p-Ar), 7.38 (d, ${ }^{3} \mathrm{~J}_{\mathrm{HH}}=7.9 \mathrm{~Hz}, 4 \mathrm{H}, m$-Dipp), 7.19 (dd, ${ }^{3} \mathrm{~J}_{\mathrm{HH}}=7.7 \mathrm{~Hz}$, $\left.{ }^{4} \mathrm{~J}_{\mathrm{HP}}=3.5 \mathrm{~Hz}, 2 \mathrm{H}, m-\mathrm{C}_{6} \mathrm{H}_{3}\right), 2.41\left(\mathrm{~h},{ }^{3} \mathrm{~J}_{\mathrm{HH}}=6.7 \mathrm{~Hz}, 4 \mathrm{H},(\mathrm{CHMe})_{\text {Dipp }}\right), 1.83\left(\mathrm{~d},{ }^{2} \mathrm{~J}_{\mathrm{HP}}=11.0 \mathrm{~Hz}, 6 \mathrm{H}\right.$, $\left.\mathrm{PMe}_{2}\right), 1.38\left(\mathrm{~d},{ }^{3} \mathrm{~J}_{\mathrm{HH}}=6.8 \mathrm{~Hz}, 12 \mathrm{H}, \mathrm{Me}_{\text {Dipp }}\right), 0.97\left(\mathrm{~d},{ }^{3} \mathrm{~J}_{\mathrm{HH}}=6.6 \mathrm{~Hz}, 12 \mathrm{H}, \mathrm{Me}_{\text {Dipp }}\right) .{ }^{13} \mathrm{C}\left\{{ }^{1} \mathrm{H}\right\} \mathrm{NMR}(100$ $\left.\mathrm{MHz}, \mathrm{CD}_{2} \mathrm{Cl}_{2}, 0{ }^{\circ} \mathrm{C}\right) \delta: 173.2\left(\mathrm{~d},{ }^{2} J_{\mathrm{CP}}=14 \mathrm{~Hz}\right.$, cis-CO), 168.7 (d, ${ }^{2} J_{\mathrm{CP}}=91 \mathrm{~Hz}$, cis-CO), 161.9 (q, ${ }^{1} J_{\mathrm{CB}}$ $=50 \mathrm{~Hz}$, ipso-Ar), 149.9 (br, o-Dipp), $144.4\left(\mathrm{~d},{ }^{2} J_{\mathrm{CP}}=11 \mathrm{~Hz}, o-\mathrm{C}_{6} \mathrm{H}_{3}\right), 135.0(o-\mathrm{Ar}), 134.0\left(\mathrm{~d},{ }^{3} J_{\mathrm{CP}}=10\right.$ $\left.\mathrm{Hz}, m-\mathrm{C}_{6} \mathrm{H}_{3}\right), 132.0\left(\mathrm{~d},{ }^{4} J_{\mathrm{CP}}=2 \mathrm{~Hz}, p-\mathrm{C}_{6} \mathrm{H}_{3}\right), 131.9$ (p-Dipp), 130.9 (d, $\left.{ }^{1} J_{\mathrm{CP}}=59 \mathrm{~Hz}, i p s o-\mathrm{C}_{6} \mathrm{H}_{3}\right), 130.5$ (br, ipso-Dipp), 129.0 (q, ${ }^{2} J_{\mathrm{CF}}=31 \mathrm{~Hz}, m$-Ar), 124.8 (q, $\left.{ }^{1} J_{\mathrm{CF}}=272 \mathrm{~Hz}, \mathrm{CF}_{3}\right), 124.5$ ( $m$-Dipp), 117.7 (m, p-Ar), $\left.32.4\left(\mathrm{CHMe}_{2}\right)_{\text {Dipp }}\right), 25.8\left(\mathrm{Me}_{\text {Dipp }}\right), 22.6\left(\mathrm{Me}_{\text {Dipp }}\right), 18.5\left(\mathrm{~d},{ }^{1} J_{\mathrm{CP}}=43 \mathrm{~Hz}, \mathrm{PMe}_{2}\right) .{ }^{31} \mathrm{P}\left\{{ }^{1} \mathrm{H}\right\} \mathrm{NMR}$ $\left(160 \mathrm{MHz}, \mathrm{CD}_{2} \mathrm{Cl}_{2}, 25^{\circ} \mathrm{C}\right) \delta:-21.0$. 
[Rh(CO) $\left.)_{3} \mathbf{P M e} \mathbf{A r}^{\prime}\right][\mathrm{BArF}]\left(\mathbf{1 1} \cdot(\mathbf{C O})_{3}\right): \mathrm{A} \mathrm{CD}_{2} \mathrm{Cl}_{2}(0.6 \mathrm{~mL})$ solution of 11 $\cdot(\mathbf{C O})(0.08 \mathrm{mmol})$, placed in a Young NMR tube, was pressurized with CO (6 bar). NMR studies carried out from 25 to $-60{ }^{\circ} \mathrm{C}$ are in accord with the presence of complexes 11·(CO) and 11•(CO)3 $\left(65: 35\right.$ (a) or 96:4 (b) ratio at $\left.-60{ }^{\circ} \mathrm{C}\right)$. Complex 11·(CO) 3 was only stable under a carbon monoxide atmosphere and its removal quickly regenerated the starting material. Consequently, characterization of $11 \cdot(\mathbf{C O})_{3}$ by NMR spectroscopy was carried out under a $\mathrm{CO}$ atmosphere (6 bar). 11a·(CO)3: ${ }^{1} \mathrm{H} \mathrm{NMR}\left(400 \mathrm{MHz}, 25{ }^{\circ} \mathrm{C}, \mathrm{CD}_{2} \mathrm{Cl}_{2}\right) \delta: 7.75$ $\left(\mathrm{td},{ }^{3} J_{\mathrm{HH}}=7.7,{ }^{5} J_{\mathrm{HP}}=2.2 \mathrm{~Hz}, 1 \mathrm{H}, p-\mathrm{C}_{6} \mathrm{H}_{3}\right), 7.43\left(\mathrm{t},{ }^{3} J_{\mathrm{HH}}=7.6 \mathrm{~Hz}, 2 \mathrm{H}, p-\mathrm{Xyl}\right), 7.31\left(\mathrm{~d},{ }^{3} J_{\mathrm{HH}}=7.6 \mathrm{~Hz}\right.$, $4 \mathrm{H}, m-\mathrm{Xyl}), 7.13\left(\mathrm{dd},{ }^{3} J_{\mathrm{HH}}=7.7,{ }^{4} J_{\mathrm{HP}}=3.5 \mathrm{~Hz}, 1 \mathrm{H}, m-\mathrm{C}_{6} \mathrm{H}_{3}\right), 2.13\left(\mathrm{~s}, 12 \mathrm{H}, \mathrm{Me}_{\mathrm{Xyl}}\right), 1.63\left(\mathrm{~d},{ }^{2} J_{\mathrm{HP}}=10.4\right.$ $\left.\mathrm{Hz}, 6 \mathrm{H}, \mathrm{PMe}_{2}\right) .{ }^{13} \mathrm{C}\left\{{ }^{1} \mathrm{H}\right\} \mathrm{NMR}\left(100 \mathrm{MHz}, 25^{\circ} \mathrm{C}, \mathrm{CD}_{2} \mathrm{Cl}_{2}\right) \delta: 182.1$ (br s, CO), $146.5\left(\mathrm{~d},{ }^{2} J_{\mathrm{CP}}=11 \mathrm{~Hz}, o-\right.$ $\mathrm{C}_{6} \mathrm{H}_{3}$ ), 138.1 (br s, ipso-Xyl), 136.9 (o-Xyl), 133.8 (br s, $p-\mathrm{C}_{6} \mathrm{H}_{3}$ ), 131.5 (d, ${ }^{3} J_{\mathrm{CP}}=9 \mathrm{~Hz}, m-\mathrm{C}_{6} \mathrm{H}_{3}$ ), 129.3 $(p-\mathrm{Xyl}), 128.7(m-\mathrm{Xyl}), 127.8\left(\mathrm{~d},{ }^{1} J_{\mathrm{CP}}=36 \mathrm{~Hz}\right.$, ipso- $\left.\mathrm{C}_{6} \mathrm{H}_{3}\right), 22.4(\mathrm{Mexyl}) .{ }^{13} \mathrm{C}\left\{{ }^{1} \mathrm{H}\right\} \mathrm{NMR}(100 \mathrm{MHz},-60$ $\left.{ }^{\circ} \mathrm{C}, \mathrm{CD}_{2} \mathrm{Cl}_{2}\right): 180.6\left(\mathrm{dd},{ }^{1} J_{\mathrm{CRh}}=69,{ }^{2} J_{\mathrm{CP}}=16 \mathrm{~Hz}\right.$, cis-CO), $178.8\left(\mathrm{dd},{ }^{2} J_{\mathrm{CP}}=92 \mathrm{~Hz},{ }^{1} J_{\mathrm{CRh}}=51 \mathrm{~Hz}\right.$, trans$\mathrm{CO}), 18.6\left(\mathrm{~d},{ }^{1} J_{\mathrm{CP}}=37 \mathrm{~Hz}, \mathrm{PMe}_{2}\right) .{ }^{31} \mathrm{P}\left\{{ }^{1} \mathrm{H}\right\} \mathrm{NMR}\left(160 \mathrm{MHz}, 25{ }^{\circ} \mathrm{C}, \mathrm{CD}_{2} \mathrm{Cl}_{2}\right) \delta:-2.3(\mathrm{br}) .{ }^{31} \mathrm{P}\left\{{ }^{1} \mathrm{H}\right\} \mathrm{NMR}$ $\left.\left(160 \mathrm{MHz},-60{ }^{\circ} \mathrm{C}, \mathrm{CD}_{2} \mathrm{Cl}_{2}\right) \delta:-1.2\left(\mathrm{~d},{ }^{1} J_{\mathrm{PRh}}=91 \mathrm{~Hz}\right) . \mathbf{1 1 b} \cdot(\mathbf{C O})\right)_{3}:{ }^{31} \mathrm{P}\left\{{ }^{1} \mathrm{H}\right\} \mathrm{NMR}\left(160 \mathrm{MHz},-60{ }^{\circ} \mathrm{C}\right.$, $\left.\mathrm{CD}_{2} \mathrm{Cl}_{2}\right) \delta:-3.5\left(\mathrm{~d},{ }^{1} J_{\mathrm{PRh}}=91 \mathrm{~Hz}\right)$.

\section{Acknowledgements}

This work has been supported by the Spanish Ministry of Economy and Competitiveness (Project CTQ2016-75193-P [AEI/FEDER, UE]). J. C. thank BBVA Foundation for a Grant for Researchers and Cultural Creators 2016 and the EU H2020 Program for a Marie Skłodowska-Curie Individual Fellowship (Grant Agreement no. 706008). J. J. M. thanks the Universidad de Sevilla for a research grant. The use of computational facilities at the Supercomputing Centre of Galicia (CESGA) is gratefully acknowledged.

Keywords: terphenyl phosphine $\bullet \pi$-arene interactions $\bullet$ hemilabile ligands $\bullet$ disproportionation $\bullet$ biaryl phosphine

\footnotetext{
${ }^{1}$ a) R. H. Crabtree in The Organometallic Chemistry of the Transition Metals, 6th ed., John Wiley \& Sons Inc, Hoboken, 2014; b) M. Bochmann in Organometallics and Catalysis. An Introduction, Oxford University Press, Oxford, 2015; (c) J. F. Hartwig in Organotransition Metal Chemistry, From Bonding to Catalysis, Sausalito, 2010; d) R. H. Crabtree, J. Organomet. Chem. 2005, 690, 5451; e) C. A. McAuliffe, W. Levason in Phosphine, Arsine and Stibine Complexes of the Transition Elements, Elsevier Scientific Pub. Co., Amsterdam, 1999; f) L. H. Pignolet in Homogeneous Catalysis with Metal Phosphine Complexes, Plenum Press, New York, 1983.

${ }^{2}$ For representative examples of low-coordinate and agostic complexes based on phosphine ligands, see; (a) W. Baratta, E. Herdtweck, P. Rigo, Angew. Chem., Int. Ed. 1999, 38, 1629; b) W. Baratta, S. Stoccoro, A. Doppiu, E. Herdtweck, A. Zucca, P. Rigo, Angew. Chem., Int. Ed., 2003, 42, 105; c) J. P. Stambuli, M. Bühl, J. F. Hartwig, J. Am. Chem. Soc., 2002, 124, 9346; d) J. P. Stambuli, C. D. Incarvito, M. Bühl, J. F. Hartwig, J. Am. Chem. Soc., 2004, 126, 1184; e) E. Fasulo, E. Calimano, J.M. Buchanan, T. D. Tilley, Organometallics, 2013, 32, 1016; f) S. D. Pike, A. L. Thompson, A. G. Algarra, D. C. Apperley, S. A.
} 
Macgregor, A. S. Weller, Science, 2012, 337, 1648.; g) A. B. Chaplin, R. Tonner, A. S. Weller, Organometallics, 2010, 29, 2710; h) R. Mathialagan, S. Kuppuswamy, A. De Denko, M. W. Bezpalko, B. M. Foxman, C. M. Thomas, Inorg. Chem., 2013, 52, 701; i) D. S. Kuiper, P. T. Wolczanski, E. B. Lobkovsky, T. R. Cundari, J. Am. Chem. Soc., 2008, 130, 12931; j) M. E. van der Boom, M. A. Iron, O. Atasoylu, L. J. W. Shimon, H. Rozenberg, Y. Ben-David, L. Konstantinovski, J. M. L. Martin, D. Milstein, Inorg. Chim. Acta, 2004, 1854, 357; k) L. Ortega-Moreno, R. Peloso, C. Maya, A. Suárez, E. Carmona, Chem. Commun., 2015, 51, 17008; I) W. H. Bernskoetter, C. K. Schauer, K. I. Goldberg, M. Brookhart, Science, 2009, 326, 553.

${ }^{3}$ See for example: a) A. Zapf, A. Ehrentraut, M. Beller, Angew. Chem., Int. Ed., 2000, 39, 4153; b) W. Xiao-Feng, F. Xianjie, W. Lipeng, R. Jackstell, H. Neumann, M. Beller, Acc. Chem. Res., 2014, 47, 1041; c) J. P. Wolfe, R. A. Singer, B. H. Yang, S. L. Buchwald, J. Am. Chem. Soc. 1999, 121, 9550; d) A. Aranyos, D. W. Old, A. Kiyomori, J. P. Wolfe, J. P. Sadighi, S. L. Buchwald, J. Am. Chem. Soc. 1999, 121, 4369; e) J. P. Wolfe, S. Wagaw, J.-F. Marcoux, S. L. Buchwald, Acc. Chem. Res. 1998, 31, 805; f) T. E. Barder, S. L. Buchwald, J. Am. Chem. Soc. 2007, 129, 5096; g) A. F. Littke, G. C. Fu, Angew. Chem., Int. Ed. 2002, 41, 4176; h) Q. Shelby, N. Kataoka, G. Mann, J. F. Hartwig, J. Am. Chem. Soc. 2000, 122, 10718; i) G. Mann, C. Incarvito, A. L. Rheingold, J. F. Hartwig, J. Am. Chem. Soc. 1999, 121, 3224; j) J. F. Hartwig, Angew. Chem. Int. Ed. 1998, $37,2046$.

${ }^{4}$ D. W. Old, J. P. Wolfe, S. L. Buchwald, J. Am. Chem. Soc. 1998, 120, 9722.

5 a) R. Martin, R., S. L. Buchwald, Acc. Chem. Res. 2008, 41, 1461; b) T. E. Barder, S. D. Walker, J. R. Martinelli, S. L. Buchwald, J. Am. Chem. Soc. 2005, 127, 4685; c) S. E. Denmark, J. M. Kallemeyn, J. Am. Chem. Soc. 2006, $128,15958$.

${ }^{6}$ a) D. S. Surry, S. L. Buchwald, Angew. Chem., Int. Ed. 2008, 47, 6338; b) D. S. Surry, S. L. Buchwald, Chem. Sci. 2011, 2, 27; c) P. Ruiz-Castillo, S. L. Buchwald, Chem. Rev. 2016, 116, 12564.

7 a) F. Tian, D. Yao, Y. Liu, F. Xie, W. Zhang Adv. Synth. Catal. 2010, 352, 1841; b) T. Iwai, T. Fujihara, J. Terao, Y. Tsuji, J. Am. Chem. Soc. 2009, 131, 6668.

${ }^{8}$ a) J. R. White, G. J. Price, P. K. Plucinski, C. G. Frost, Tet. Lett. 2009, 50, 7365; b) E. Rafter, D. G. Gilheany, J. N. H. Reek, P. W. N. M. van Leeuwen ChemCatChem 2010, 2, 387; c) P. K. Dhondi, P. Carberry, L. B. Choi, J. D. Chisolm, J. Org. Chem. 2007, 72, 9590; d) P. K. Dhondi, J. D. Chisolm, Org. Lett. 2006, 8, 67.

${ }^{9}$ Z. Liu, J. F. Hartwig, J. Am. Chem. Soc. 2008, 130, 1570.

${ }^{10}$ Z. Liu, H. Yamamichi, S. T. Madrahimov, J. F. Hartwig, J. Am. Chem. Soc. 2011, 133, 2772.

${ }^{11}$ A. R. O'Connor, W. Kaminsky, D. M. Heinekey, K. I. Goldberg, Organometallics 2011, 30, 2105.

${ }^{12}$ A. R. O'Connor, W. Kaminsky, B. C. Chan, D. M. Heinekey, K. I. Goldberg, Organometallics 2013, 32, 4016.

${ }^{13}$ a) X. Qiu, M. Wang,Y. Zhao, Z. Shi, Angew.Chem. Int.Ed. 2017, 56, 7233; b) M. Bera, S. Agasti, R. Chowdhury, R. Mondal, D. Pal, D. Maiti, Angew.Chem. Int. Ed. 2017, 56, 5272.

${ }_{14}$ a) T. E. Barder, S. L. Buchwald, J. Am. Chem. Soc. 2007, 129, 5096; b) T. E. Barder, M. R. Biscoe, S. L. Buchwald, Organometallics 2007, 26, 2183; c) H. Tomori, J. M. Fox, S. L. Buchwald, J. Org. Chem. 2000, 65, 5334.

${ }^{15}$ A. E. Strom, D. Balcells, J. F. Hartwig ACS Catal. 2016, 6, 5651.

${ }^{16}$ a) R. C. Smith, R. A. Woloszynek, W. Chen, T. Ren, J. D. Protasiewicz, Tetrahedron Lett. 2004, 45, 8327; b) B. Buster, A. A. Diaz, T. Graham, R. Khan, M. A. Khan, D. R. Powell, R. J. Wehmschulte, Inorg. Chim. Acta 2009, 362, 3465; c) D. V. Partyka, M. P. Washington, J. B. Updegraff III, X. Chen, C. D. Incarvito, A. L. Rheingold, J. D. Protasiewicz, J. Organomet. Chem. 2009, 694, 1441; d) M. F. Espada, J. Campos, J. López-Serrano, M. L. Poveda, E. Carmona, Angew. Chem., Int. Ed. 2015, 54, 15379; e) S. Sasaki, R. Chowdhury, M. Yoshifuji, Tetrahedron Lett. 2004, 45, 9193; f) S. Sasaki, M. Izawa, M. Yoshifuji, Phosphorus, Sulfur Silicon Relat. Elem. 2014, 189, 1207; g) T. Fujihara, K. Semba, J. Terao, Y. Tsuji, Angew. Chem., Int. Ed. $2010,49,1472$.

17 a) L. Ortega-Moreno, M. Fernández-Espada, J. J. Moreno, C. Navarro-Gilabert, J. Campos, S. Conejero, J. López-Serrano, C. Maya, R. Peloso, E. Carmona, Polyhedron 2016, 116, 170; b) J. Campos, L. Ortega-Moreno, S. Conejero, R. Peloso, J. LópezSerrano, C. Maya, E. Carmona, Chem. - Eur. J. 2015, 21, 8883; c) L. Ortega-Moreno, R. Peloso, C. Maya, A. Suárez, E. Carmona, Chem. Commun. 2015, 51, 17008; d) J. Campos, J. Am. Chem. Soc. 2017, 139, 2944.

${ }_{18}$ M. F. Espada, J. Campos, J. López-Serrano, M. L. Poveda, E. Carmona, Angew. Chem., Int. Ed. 2015, 54, 15379.

19 a) S. Michlik, R. Kempe, Nat. Chem. 2013, 5, 140; b) J. Graeupner, T. P. Brewster, J. D. Blakemore, N. D. Schley, J. M. Thomsen, G. W. Brudvig, N. Hazari, R. H. Crabtree, Organometallics 2012, 31, 7158; c) M. Prinz, L. F. Veiros, M. J. Calhorda, C. C. Romão, E. Herdtweck, F. E. Kühn, W. A. Herrmann, J. Organomet. Chem. 2006, 691, 4446; d) C. G. Pierpont, Inorg. Chem. 1979, 18, 2972-2977.

${ }^{20}$ R. H. Crabtree, Acc. Chem. Res., 1979, 12, 331.

${ }^{21}$ P. G. Andersson, Iridium Catalysis. Top. Organomet. Chem. 2011, Springer-Verlag Berlin Heidelberg.

22 See for instance: a) R. Uson, L. A. Oro, C. Foces-Foces, F. H. Cano, S. García-Blanco, M. Valderrama, J. Organomet. Chem. 1982, 229, 293 ; b) R. Uson, L. A. Oro, C. Foces-Foces, F. H. Cano, A. Vegas, M. Valderrama, J. Organomet. Chem. 1981, 215, 241.

${ }^{23}$ (a) T. J. Geldbach, D. Drago, P. S. Pregosin, J. Organomet. Chem. 2002, 643, 214; b) S. M. Reid, R. C. Boyle, J. T. Mague, M. J. Fink, J. Am. Chem. Soc. 2003, 125, 7816; c) J. R. Krumper, M. Gerisch, A. Magistrato, U. Rothlisberger, R. G. Bergman, T. D. Tilley, J. Am. Chem. Soc. 2004, 126, 12492; d) C. Barthes, C. Lepetit, Y. Canac, C. Duhayon, D. Zargarian, R. Chauvin, Inorg. Chem. 2013, 52, 48; e) J. Cámpora, J. A. López, P. Palma, P. Valerga, E. Spillner, E. Carmona, Angew.Chem. Int. Ed. 1999, 38, 147; f) S. D.Walker, T. E. Barder, J. R. Martinelli, S. L. Buchwald, Angew.Chem. Int. Ed. 2004, 43, 1871; g) C. Lepetit, J. 
Poater, M. E. Alikhani, B. Silvi, Y. Canac, J. Contreras-García, M. Solá, R. Chauvin, Inorg. Chem. 2015, 54, 2960; h) M. A. Esteruelas, D. Gómez-Bautista, A. M. López, E. Oñate, J.-Y. Tsai, C. Xia, Chem. Eur. J. 2017, 23, 15729.

${ }^{24}$ A. Falceto, E. Carmona, S. Alvarez, Organometallics 2014, 6660.

25 L. Cavallo, A. Macchioni, C. Zuccaccia, D. Zuccaccia, I. Orabona, F. Ruffo, Organometallics 2004, 2137.

${ }^{26}$ H. Werner, G. Canepa, K. Ilg, J. Wolf, Organometallics 2000, 19, 4756.

${ }^{27}$ A. R. Chianese, X. Li, M. C. Janzen, J. W. Faller, R. H. Crabtree, Organometallics 2003, 22, 1663.

28 a) J. Campos, L. S. Sharninghausen, M. G. Manas, R. H. Crabtree, Inorg. Chem. 2015, 54, 5079; b) L. S. Sharninghausen, J. Campos, M. G. Manas, R. H. Crabtree, Nat. Commun., 2014, 5, 5079; c) M. G. Manas, J. Campos, L. S. Sharninghausen, E. Lin R. H. Crabtree, Green. Chem. 2015, 17, 594.

${ }^{29}$ O. Diebolt, G. C. Fortman, H. Clavier, A. M. Z Slawin, E. C. Escudero-Adán, J. Benet-Buchholz, S. P. Nolan, Organometallics 2011, 30, 1668.

30 a) P. Dotta, P. G. A. Kumar, P. S. Pregosin, A. Albinati, S. Rizzato Organometallics 2004, 23, 4247; b) T. J. Geldbach, D. Drago, P. S. Pregosin J. Organomet. Chem. 2002, 643-644, 214-222; c) T. J. Geldbach, F. Breher, V. Gramlich, P. G. A. Kumar, P. S. Pregosin Inorg. Chem. 2004, 43, 1920.

31 a) H. Werner, Dalton Trans. 2003, 3829; b) H. Werner, G. Canepa, K. Ilg, J. Wolf, Organometallics 2000, $19,4756$.

${ }^{32}$ Bader, R. F. W. Atom in Molecules: A Quantum Theory; Oxford University Press: Oxford, U.K., 1995.

33 a) A. S. C. Chan, H.-S. Shieh, Inorg. Chimica Acta, 1994, 218, 89; b) G. Zotti, S. Zecchin, G. Pilloni J. Organomet. Chem. 1983, 246, 61.

xxxiv G. Giordano, R. H. Crabtree, Inorg. Synth. 1990, 28, 86-92.

${ }^{x x x v}$ a) B. Buster, A. A. Diaz, T. Graham, R. Khan, M. A. Khan, D. R. Powell, R. J. Wehmschulte, Inorg. Chim. Acta 2009, 362, 3465 b) J. Campos, L. Ortega-Moreno, S. Conejero, R. Peloso, J. López-Serrano, C. Maya, E. Carmona, Chem. Eur.J. 2015, 21, 8883.

xxxvi L. Ortega-Moreno, R. Peloso, C. Maya, A. Suárez, E. Carmona, Chem. Commun., 2015, 51, 17008.

xxxvii N. A. Yakelis, R. G. Bergman, Organometallics 2005, 24, 3579. 